Portland State University

PDXScholar

$5-6-2010$

\title{
On Family and Fences: Tracing Melungeon Roots in the Blue Ridge Mountains of Virginia and Tennessee
}

Ron Horton

Portland State University

Follow this and additional works at: https://pdxscholar.library.pdx.edu/open_access_etds

Part of the Creative Writing Commons

Let us know how access to this document benefits you.

\section{Recommended Citation}

Horton, Ron, "On Family and Fences: Tracing Melungeon Roots in the Blue Ridge Mountains of Virginia and Tennessee" (2010). Dissertations and Theses. Paper 1974.

https://doi.org/10.15760/etd.1973

This Thesis is brought to you for free and open access. It has been accepted for inclusion in Dissertations and Theses by an authorized administrator of PDXScholar. Please contact us if we can make this document more accessible: pdxscholar@pdx.edu. 


\section{On Family and Fences:}

Tracing Melungeon Roots in the Blue Ridge Mountains of Virginia and Tennessee

by

\section{Ron Horton}

\section{A thesis submitted in partial fulfillment of the} requirements for the degree of

\section{MASTER OF FINE ARTS \\ in \\ CREATIVE WRITING}

Thesis Committee:

Paul Collins, Chair

Amy Greenstadt

Michael McGregor

Portland State University

2010 


\begin{abstract}
An abstract of the thesis of Ron Horton for the Master of Fine Arts in Creative Writing presented May 6, 2010.
\end{abstract}

Title: On Family and Fences: Tracing Melungeon Roots in the Blue Ridge Mountains of Virginia and Tennessee.

The Melungeons are a group of indeterminable origin living in the Blue Ridge Mountains of Southeastern Tennessee and Southwestern Virginia. This thesis describes characteristics of these tri-racial isolates and gives theories as to their mysterious origins. Being darker skinned, the Melungeons were pushed into more mountainous regions by European colonists in the early 1700's. While multiple hypotheses exist as to the origin of the Melungeon people, there is no single theory that is accepted by all scholars.

Dr. Brent Kennedy's The Melungeons: The Resurrection of a Proud People, served as a catalyst for my Melungeon research. Kennedy is my cousin, and his book provided facts behind the family stories I recalled from childhood. It also linked me to other famous Melungeons such as Brandy Jack Mullins and Mahala Mullins. Although there are an abundance of stories and facts about my Melungeon heritage, there is also much history that has been lost. 
This thesis traces my Melungeon roots, following the family stories of N.B. Kennedy, Brandy Jack Mullins, Mahala Mullins, and Kenneth Kennedy. In order to fully understand these people and their stories, I not only researched their history, but I also visited the areas where they lived and died. In this manner, I was able to gain a better understanding my own family as well as the history of the Melungeons.

A person's past is pieced together through oral history, written records, fading pictures, and personal artifacts. Along with these methods, we as writers and researchers add a bit of our own thought and imagination to fill in the gaps of a person's life. In this manner, personal mythology is created. This thesis ends with an example of one fictionalized story from my family surrounding the death of my uncle, Kenneth Kennedy. 
Dedicated to Kenneth Kennedy 


\section{Acknowledgements}

I would like to acknowledge the following people for their help in the creation of this thesis: Ron Horton Sr., Sandy Horton, Karen Kennedy, Brent Kennedy, Brent Kennedy Sr., Richard Kennedy, Amy Kiser, Ruby Kennedy Kiser, and Ginger Senter. I would also like to thank my thesis committee consisting of Paul Collins, Dr. Amy Greenstadt, and Michael McGregor. 


\section{Table of Contents}

Dedication: Pg. $i$

Acknowledgements: Pg. ii

List of Figures: Pg. $v$

I. Prologue Pg. 1

A. Recording Family Stories Pg. 1

B. Discovering Our Family’s Melungeon Roots Pg. 5

II. Introduction: The Melungeons Pg. 10
A. Theories on the Origins of the Melungeons Pg. 10
B. Legal Definition of Melungeons Pg. 16
C. The Loss of Rights Pg. 19
D. Early Writings on the Melungeons Pg. 21

III. My Melungeon Roots Pg. 24
A. My Initial Interest in Melungeons Pg. 24
B. Reconnecting with the Past Pg. 26
C. Fact Inspires Fiction Pg. 28

IV. Brandy Jack Mullins Pg. 31
A. Family Life Pg. 33
B. Brandy Jack the Counterfeiter Pg. 34
C. Related Myth and Tall Tales Pg. 37
D. Sorting Fact From Fiction Pg. 38

V. Tracing the Path of Brandy Jack: A Trip to Caney Ridge Pg. 41
A. Meeting Ginger Senter: Caney Ridge Historian Pg. 45
B. N.B. Kennedy's Life on Caney Ridge Pg. 49
C. Historical Mythology Pg. 53

VI. Mahala Mullins Pg. 59
A. History Pg. 60
B. Illicit Trade and Violence Pg. 62
C. Myths and Tall Tales Pg. 65
D. The Queen of Moonshine Pg. 66 
VII. Following the Trail of Mahala Mullins Pg. 69
A. Touring Sneedville Pg. 69
B. Traveling to Vardy Pg. 73
C. Visiting the Mahala Mullins Cabin Pg. 76
D. Searching for the path to Newman's Ridge Pg. 81

VIII. History as Myth Pg. 85
A. The Concept of Mythmaking Pg. 85
B. Conversations with Karen Kennedy Pg. 88
C. Creating Personal Myth: The Writing of “Coal Black Heart” Pg. 92

IX. Coal Black Heart: A Fictionalized Interpretation of a Family Story Pg. 94

X. References Pg. 110
A. Works Cited Pg. 110
B. Photo Credits Pg. 112
C. Appendix A: The Racial Integrity Law of 1924 Pg. 114
D. Appendix B: A Letter by Walter Plecker Pg. 116 


\section{List of Figures}

1.1. N.B. Kennedy. Pg. 2

1.2. Dr. Brent Kennedy. Pg. 5

1.3. Cesme, Turkey road sign connected to Wise. Pg 7

1.4. Turkish Sign in Wise, Virginia. Pg. 7

1.5. First Printing of Brent Kennedy's The Melungeons: The Resurrection of a Proud People. Pg. 8

2.1. Typical Darkened Skin of Early Melungeons. Pg. 10

2.2. The "Croatan" mark on tree at Roanoke Colony. Pg. 12

2.3. The Bat Creek Stone. Pg. 13

2.4. The Metcalf Stone. Pg. 14

2.5. Hernando De Soto. Pg. 15

2.6. Lewis Shepherd's Memoirs. Pg. 17

2.7. A sample document from Tennessee's court system stripping legal rights from Melungeons. Pg. 19

2.8. Will Allen Dromgoole circa 1890. Pg. 22

3.1. Brent and Richard Kennedy. Pg. 24

3.2. William Jennings Kiser's Headstone. Pg. 28

3.3. Brandy Jack Mullins Family Tree. Pg. 29

4.1. Brandy Jack Mullins. Pg. 31

4.2. Samples of Brandy Jack's counterfeiting tools and coins that he made. Pg. 36

4.3. An Elderly Brandy Jack. Pg. 39

5.1. The author standing in the shadow of Brandy Jack's grave. Pg. 41

5.2. Site of Brent Kennedy Sr's service station, formerly Beverly Hills Tourist Cabins. Pg. 42

5.3. Brent Kennedy Sr., Sandy Kiser, and Karen Kennedy in front of Kennedy Auto Sales. Pg. 43

5.4. Sandy Horton on the porch of N.B. Kennedy and Tessie Colley's original house. Pg. 48

5.5. Tessie Colley with the Kennedy children on her last day with them. Pg. 50

5.6. Mullins Family Graveyard at Lebanon Church with fine hand-wrought metal sign. Pg. 54

5.7. Original Brandy Jack gravestone with valley view in background. Pg. 56

5.8. Newer Brandy Jack stone with wrong date, making him 103 at his death. Pg. 57

5.9. Ginger Senter and Sandy Horton at one of Brandy Jack’s gravestone. Pg. 58 
6.1. Mahala Mullins, suffering from Elaphantitis, weighed over 500 pounds. Pg. 60

6.2. The Mahala Mullins Cabin fell into disrepair in its original location on Newman's Ridge. Pg. 61

6.3. Mahala Mullins in earlier years. Pg. 64

6.4. A magazine dramatization of Mahala's life as a Moonshiner. Pg. 67

7.1. Ron Horton Sr. in front of the old Sneedville Jail. Pg. 71

7.2. Sign to Vardy and Mahalia (spelling variation) Cabin. Pg. 74

7.3. New Vardy location of Mahala Mullins Cabin with Newman's Ridge in background. Pg. 77

7.4. View from front porch with plaque and inner hallway door. Pg. 78

7.5. View of cabin door, woodwork, and ornate windows. Pg. 79

7.6. Interior of Mahala Mullins Cabin furnished with period furniture. Pg. 80

7.7. Vardy Church: the center of the Vardy Community then and now. Pg. 81

7.8. Blackwater Valley: Home to Vardy Community and the relocated Mahala Mullins Cabin. Pg. 82

7.9. Example of easy accessibility of historic Melungeon locations and information. Pg. 84

8.1. Photo array of Kenneth from age 7-20. He died at age 25. Pg. 86

8.2. Karen Kennedy and daughter, Heather Kennedy. Pg. 88

8.3. Kenneth Kennedy s/o N.B. and Tessie (Colley) Kennedy. Pg. 89

8.4. Kenneth Kennedy relics: For God and Country medal, tin type signature stamp, and pilot wings. Pg. 90

8.5. Kenneth Kennedy’s footstone. Pg. 92 


\section{Prologue}

Growing up in Richmond, Virginia, the capital of the Confederacy, I grappled with a Southern identity that I just couldn’t quite accept. Living every day in a land that still harbored deep resentment at having lost a war from another century, my role was well defined, like some predestined path. During the 1970’s in any Southeastern city or town where the rebel flag had once been raised, the evolution of true racial acceptance had yet to become a reality.

I had always assumed that my relatives were in the Confederate Army during the Civil War. When Richmond was burned by Union troops, the capital moved to Petersburg, some fifteen miles further south. Eighteen years of my existence took place between these two historic cities, but I never felt comfortable with my Confederate heritage. My family had names like Kennedy, Kiser, and Cottle, and my pale, white skin burned and freckled in the southern, summer sun. I naturally thought that I was about as Anglo-Saxon as could be.

\section{Recording Family Stories}

My need to understand my roots, the history of my family, is by no means a new concept to me. As far back as my memory stretches, I've been a collector of tales. Even as a little kid, I would walk around everywhere with a tape recorder; these were the days before walkmen or iPods. I would religiously carry the oversized, black RCA machine around the house, to school, to the mall, and always on the long family trips we took to the mountains. At times I was innocently 
playing music, but just as often as not, I was recording the world around me.

Sometimes I had victims under my surveillance surreptitiously, but other times I would lay the cards, or recorder as it may be, on the table and perform interviews.

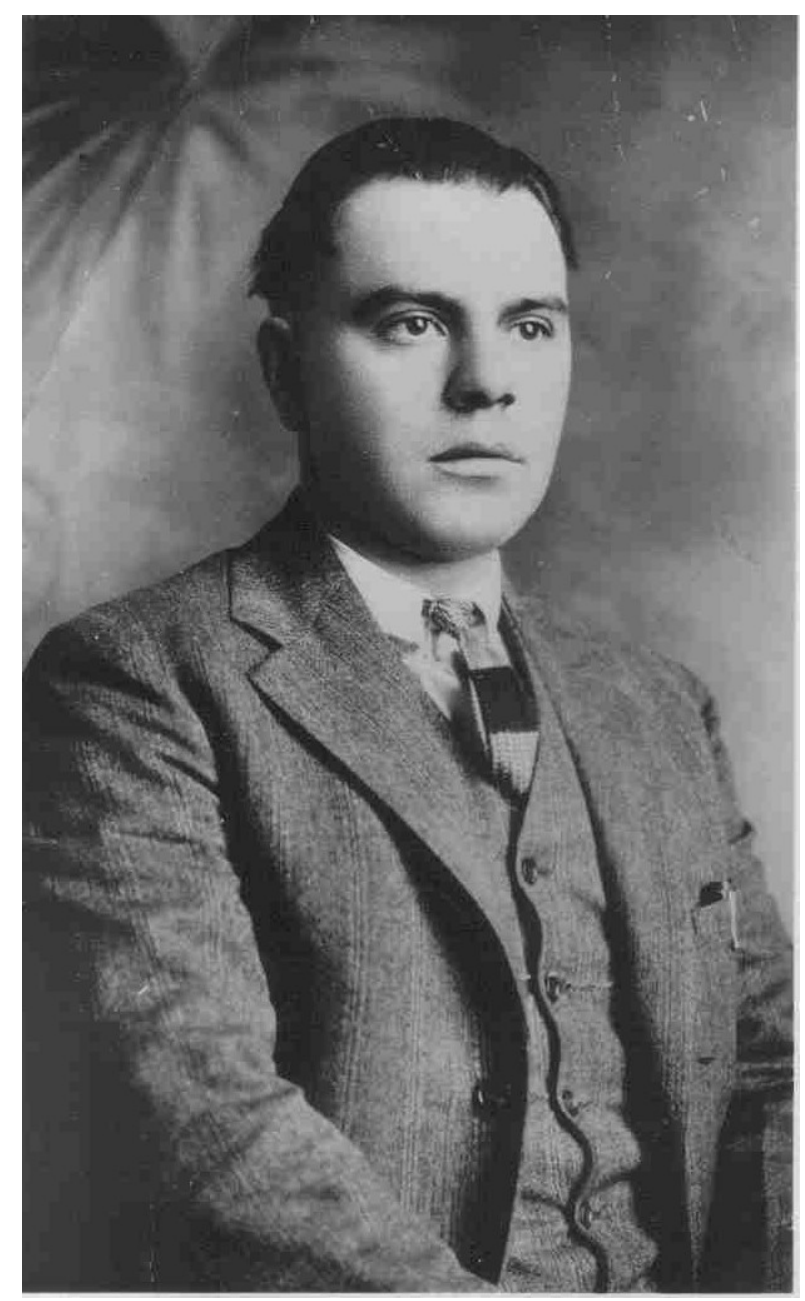

1.1 N.B. Kennedy

One of these makeshift talk shows took place in the kitchen of my great grandfather, Napolean Bonaparte Kennedy, as the whole family sat around the table after dinner. There was never a need for prepared questions. I just sat the clunky 1970's recorder on the table, pressed play and record simultaneously, and let 
technology do the rest. Listening now, some thirty years later to those recordings, I am haunted by their voices.

The first to speak is my grandfather, Jen Kiser, with voice tempered gravel coarse by Salems and Old Crow. His words loom across time over the flawed lines of monofilament or whatever tape is made of. He would die later that year... heart failed, liver failed, breath stopped. The first memoir I ever wrote was on this man, long before I even knew to call it memoir; it was simply a story. It began with my memory of a fishing trip and ended with the cliché of why bad things happen to good people.

Next to speak is my great grandfather, N.B. Kennedy. Even on this aging tape, weathered by years of replaying, his voice has audible scars. The deep set southern drawl dips, dives, winds around a bend in logic, scales past mountains of lies and truth. He begins his remembrance of growing up in the mountains without a hint of regret, "Left home when I was seven or eight...hopped that train and didn’t look back for years. Only regret I have is not killing that bitch of a mother a mine before I was gone.” It all sounds so simple.

While N.B. Kennedy would tell stories of murder, death, and deceit without blinking an eye, there were two things he wouldn’t talk about. Even at the age of six, I had been briefed in full to never bring up his son, Kenneth, who died in a coal mining accident in 1947. The very fact that there could even exist a man related to me who was dead as long as my own father had been alive proved almost too much 
for me to avoid, but I managed to steer clear of it by not wanting to imagine the consequences.

I understood my great grandfather not wanting to recount the tragic events of his son's death, but the second topic confused me. I was never to mention his Melungeon heritage. I could barely pronounce the word “Muh-lunge-uhn,” let alone guess at its definition or why the topic shouldn't be broached. My imagination was awash with theories about secret societies, forgotten tribes, lost or hidden treasure from a vanishing race. It was not until years later, more than a decade after N.B. Kennedy's demise, that I would come to understand what it meant to be Melungeon and why I have always been drawn to the mystery of my family's lost heritage.

Why am I drawn to the dark? Edgar Allen Poe calls this phenomenon the "Imp of the Perverse": it is the slowing of traffic as the passers-by stare at the wreck, whether through cracks in fingers or with a slight shaking of the head, mesmerized by the thought that it could have been us and still could be under slightly different circumstances.

Jen Kiser died in 1977, and N.B. followed suit nearly a decade later in 1986. Sitting at the dinner table in Wise, Virginia with my tape recorder in the midst of my family, I could neither dream nor predict the future. How was I to know that this moment, now past, but present at the time, would be the only audible record that these two men once walked, lived, loved... If I left that recorder running, had an endless amount of tape, would they still be alive? 


\section{Discovering Our Family’s Melungeon Roots}

N.B.'s grandson and my cousin, Brent Kennedy, was to be the catalyst for our family’s re-discovery of its Melungeon heritage. In his early forties, he became ill and began losing weight; his physical energy waned. Rather than approaching his declining health with fear and dread, Brent took an analytical approach. He was diagnosed with a rare blood disease only found in people of Middle-Eastern descent. Using this scientific fact as a clue, Brent began tracing our family’s origins, which led him to the Melungeons.

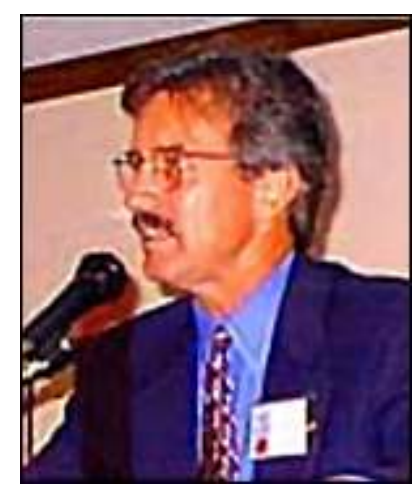

1.2 Dr. Brent Kennedy

The Melungeons were some of the earliest emigrants to reach the Southeast section of what would later become the United States. Some of their kin date back prior to the original Roanoke Colony. They have certain striking physical characteristics that separate them from their European counterparts: darker hair, olive complexion, cranial ridges, and shovel teeth. Early Melungeon settlers made their way inland, blending with the local Indian tribes and prospering as farmers 
amid the lush landscape of the Southern Piedmont, thriving off the plentiful game and rich, fertile soil.

More European settlers arrived in the late $17^{\text {th }}$ and early $18^{\text {th }}$ centuries and, seeing that these darker skinned, racially mingled people had already taken the best land, began evicting them from their settlements. They were pushed further west into the densely forested hills and rugged mountain ridges. While the Melungeons chose to live in harmony with indigenous peoples, the newer settlers wanted the land to themselves. With continued colonization, the Melungeons became secondclass citizens, looked upon with shame and scorn.

My relatives were deemed Free People of Color, much like the freed African American slaves, and they were persecuted well after the Civil War had ended. Their rights of land ownership, suffrage, and education were stripped from them simply because the darker color of their skin and their family name. While all of this information came as a shock, it helped me to reconcile my feelings of disassociation with my Southern culture; it aided me in understanding that, although I grew up in mainstream, Southern suburbia, I was and always would be an outsider.

My mother reminded me of something that my Uncle Cecil Kiser used to say: "Anything worth owning has a fence built around it." I never quite understood what he meant by this statement. Now some thirty years later, his words resonate in my mind as I search for the truth about the Melungeons behind their mysterious origins and secretive culture. I want to own my Melungeon 
heritage with these words, but there is an invisible barrier, both of place and time surrounding them, guarding their secrets from the outside world.

Through research and questioning as to our family’s true origin, Brent Kennedy unearthed a secret that had been hidden for years, tucked away in the cellars and closets. He made a major connection between the Melungeons of Virginia and Tennessee and people from the country of Turkey. Articles on the topic of the Melungeon/ Turkish connection have been written in the past few years by both Brent Kennedy and Turkish author, Mehmet Cakir. The connection between these two cultures is based on a series of comparisons: linguistic, genetic, medical, and cultural. Kennedy's association with Turkey has led to the far removed cities of Wise, Virginia and Cesme, Turkey becoming sister cities. Members of the Melungeon Heritage Association have visited Cesme on several scheduled trips, and the people of Turkey have sent researchers to the small city of Wise, Virginia to tour rural Appalachia as well.

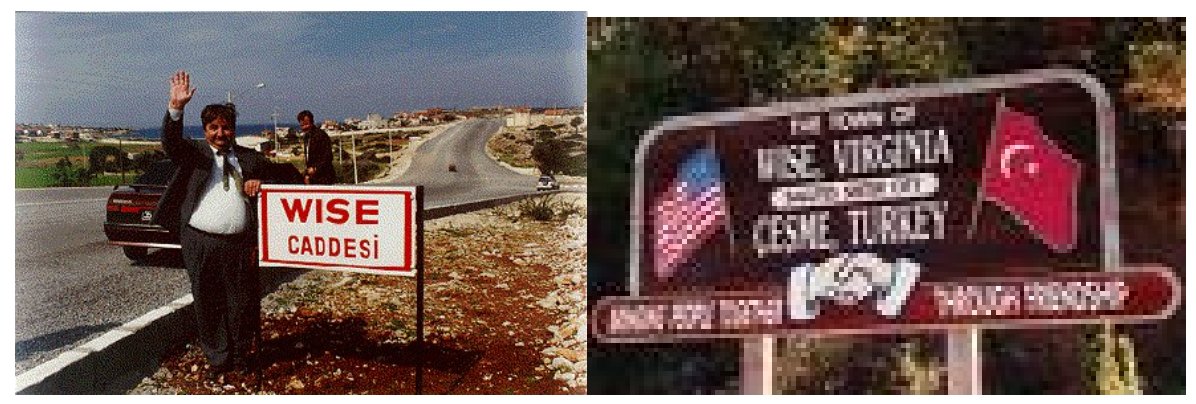

1.3 Cesme, Turkey road sign connected to Wise. $\quad$ 1.4 Turkish Sign in Wise, Virginia With the help of Dr. Kevin Jones, Kennedy further explored the Melungeon/ Turkish connection by using DNA samples from the hair and cheeks of 130 participants in 2000. These samples helped researchers make a genetic 
connection between people of Melungeon descent and those of Turkish descent. Kennedy further explored this link in the book, From Anatolia to Appalachia: A Turkish-American Dialogue, that he co-authored with colleague and fellow Melungeon scholar, Joseph Scolnick Jr.

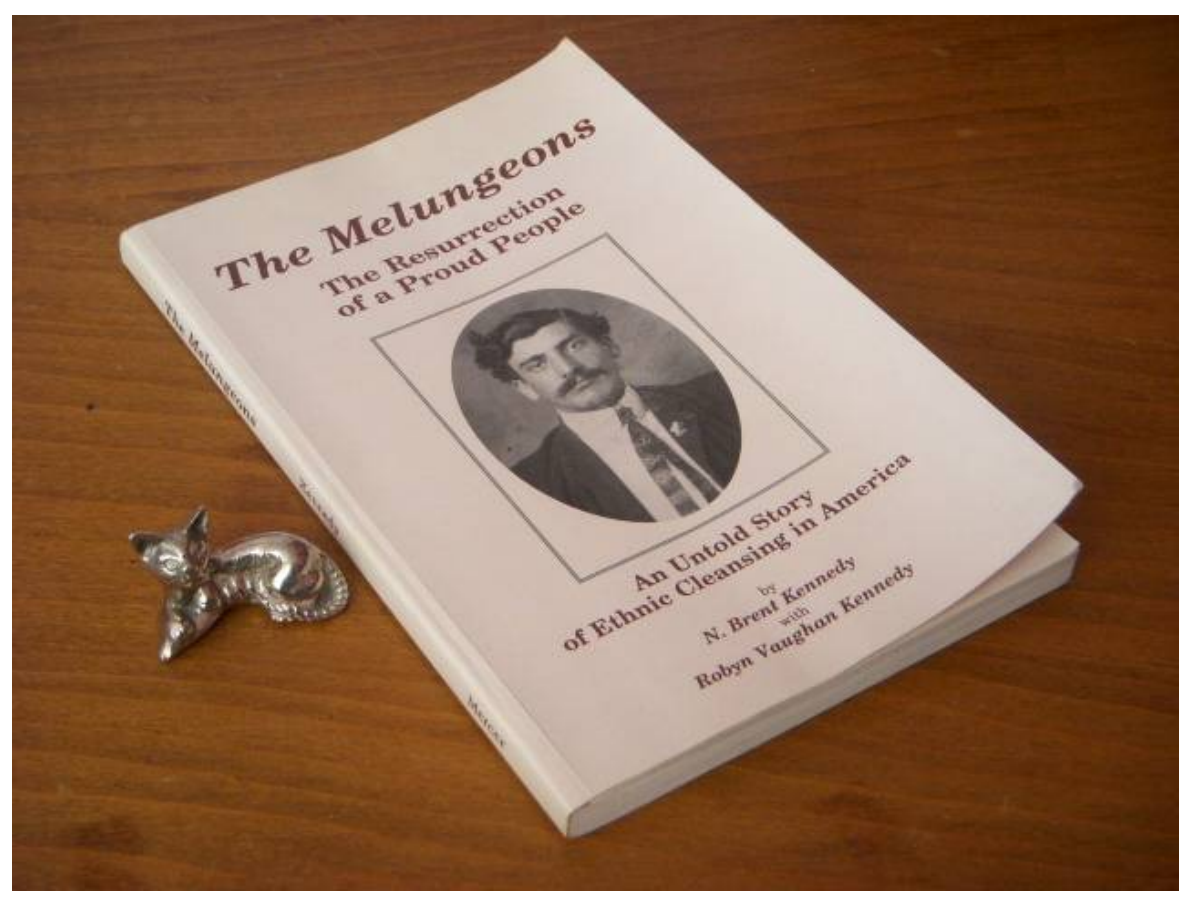

1.5 First Printing of Brent Kennedy’s, The Melungeons: The Resurrection of a Proud People

Brent emailed me in 2001, "You may be interested to know that we are well into the DNA work, and the results are fascinating...We also now know from DNA (Y-chromosone) that the Kennedys are not European. Closest matches appear to be gypsies or possibly the Black Sea region of Turkey. The original name shows up in the earliest census reports as 'Canide.’”

The clues had been there all along, but no one cared to pick the shattered pieces from the ground and put them back together. Brent Kennedy’s discovery that 
the diseased blood flowing through his veins was born a world away from Europe uncovered a truth that his forebears, my ancestors, had fought long and hard to bury for years. We belong to a group of people with a forgotten past. Much history has been lost by years of hiding our identity to fit into a mainstream culture that did not accept our racial and cultural differences. We are Melungeons. 


\section{Introduction}

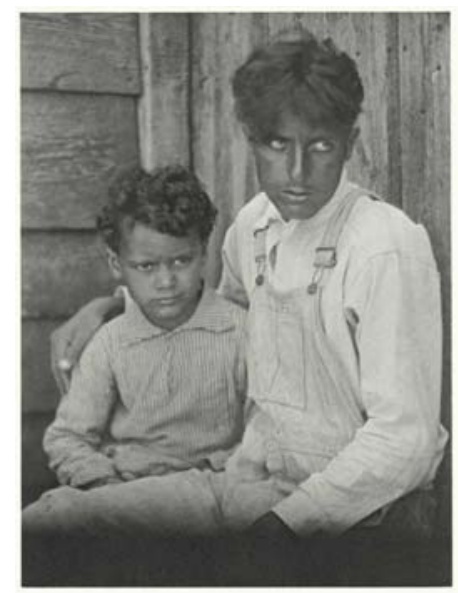

2.1 Typical Darkened Skin of Early Melungeon Settlers

\section{Theories on the Origins of the Melungeons}

Contemporary researchers have sorted through the many theories on the mysterious origins of the Melungeons. Early historians and genealogical scholars thought that they were related to original members of the Roanoke "Lost Colony." Others claimed they were descendents of the $12^{\text {th }}$ century Welsh explorer Madoc, one of the lost tribes of Israel, or shipwrecked Portuguese sailors who wandered inland. The etymology of the word can support all of these theories. The Portuguese word melungo means shipmate; the French word mélange means mixed; and the Arabic melun jinn means a cursed soul abandoned by god.

One final theory that remains popular is that the Melungeons are descended from the ancient Phoenicians or Carthaginians due to their physical appearance, and this idea is supported by census records of the early 1800's when Melungeon 
families claimed to be originally from some distant foreign land as an attempt to account for their darker skin so as not to be labeled "Free People of Color."

Bonnie Ball, a local news correspondent and noted historian from Southwest Virginia, wrote several books and articles as early as 1969 on the Melungeon's origins. She championed the theory that the group originated from the "Lost Colony" in the late $16^{\text {th }}$ century. The colony of Roanoke Island, just off the coast of modern day North Carolina in the Outer Banks region, was initially settled in 1584 with fifteen men who died, presumably at the hands of Native Americans. Captain John White returned to the colony in July of 1587 with 150 colonists. By August they had rebuilt the original structures of the previous colony, and on the $18^{\text {th }}$ of that same month the first child, Virginia Dare, was born in the New World. The colony thrived at first, but attempts to gain supplies from England were thwarted by the ongoing war with Spain. When supply ships were finally able to reach the Roanoke settlement in August of 1588, they found no human trace of the colonists, only footprints in the sand and the enigmatic letters CRO, presumably referring to the nearby tribe of Croatan Indians, carved in a tree. Whether the natives came to the aid of the colonists or simply killed them has never been determined, although the presence of blue-eyed Indians speaking broken English argued for intermarriage and assimilation. While this wonderful unsolved mystery provides the perfect canvas on which to paint the origins of the Melungeon race, there are several problems with the theory. Although the time frame of the late sixteenth century is accurate, and Melungeons have English 
surnames and originally spoke mixed Elizabethan dialect, their general appearance is more Mediterranean than mixed English and Indian.

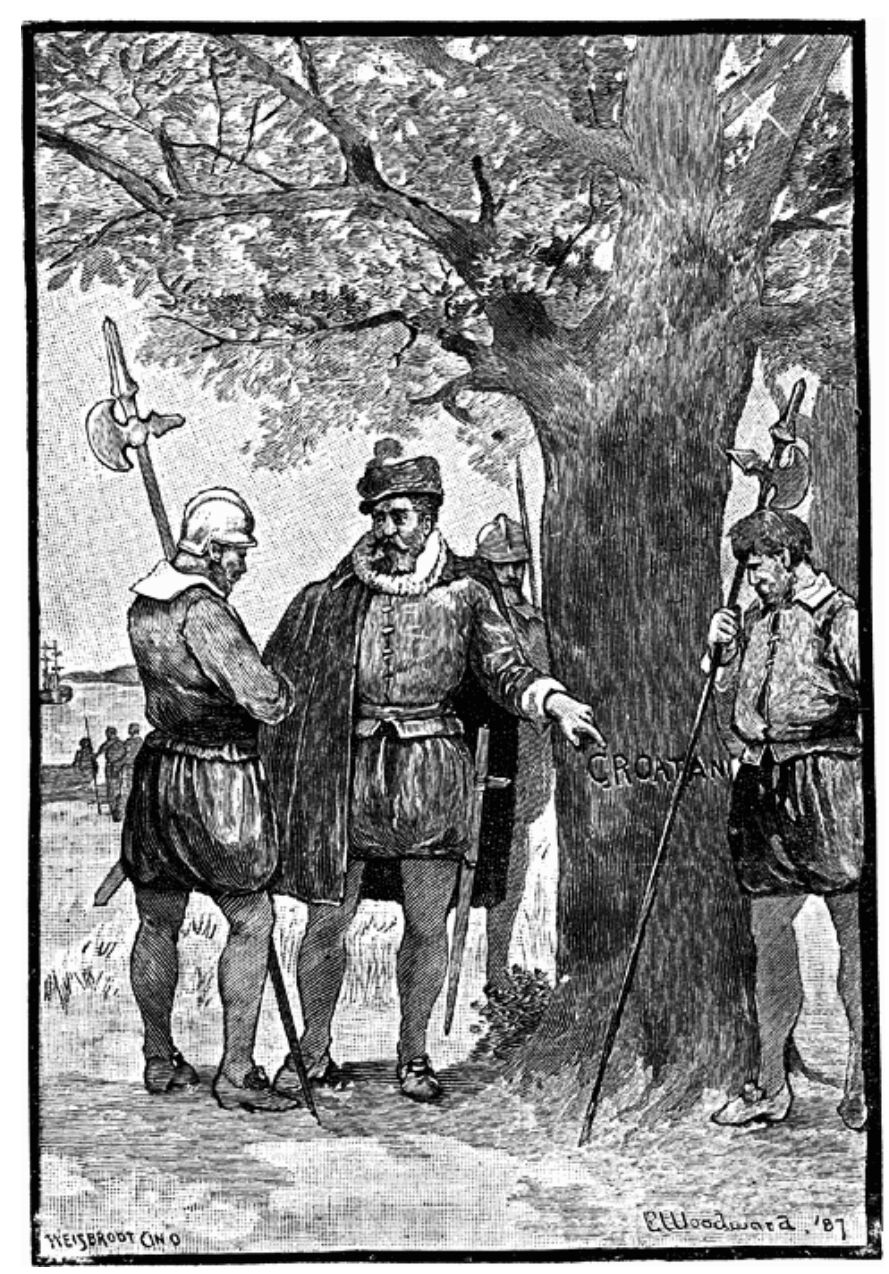

2.2 The “Croatan” mark on tree at Roanoke Colony

Elizabeth Hirschman does provide some explanation for this. Some names on the list of passengers who colonized the Roanoke settlement were French/Mediterranean and Jewish in origin. Fearing the Spanish invasion of England and their own imminent persecution, they would have been among some of the first to sign up for the dangerous journey to the new world. The navigator for the ship, Simon Fernando (Fernandez), was from Portugal, which could explain 
some early claims that the Melungeons were descended from Portuguese sailors. There were even several metal smiths among the group: William Browne, a goldsmith, and Joachim Ganz (on a separate trip to Roanoke with Sir Walter Raleigh), a metallurgist in gold and silver, which could explain the later Melungeon proclivity for counterfeiting gold and silver coins

These ideas of origin, while entirely plausible, were advanced alongside alternative claims. The discovery in Clay County, Kentucky of Bar Kokhba coins from the time of the Hebrew Rebellion against Rome in 132-134 AD, along with two stones bearing ancient Phoenician script, led some researchers and historians to link the early settlers of these areas with the Lost Tribe of Israel. The Bat Creek Stone was found in Tennessee beneath one of nine skeletons in an Indian burial mound in 1885. The stone's inscription was originally believed to be of the Cherokee language. But turned upside down, it later came to be recognized as the Phoenician language, roughly translated as "for the land of Judah.” The authenticity of this evidence is often dismissed, as "Lost Tribe" theories were quite popular during the $19^{\text {th }}$ century in many religions.

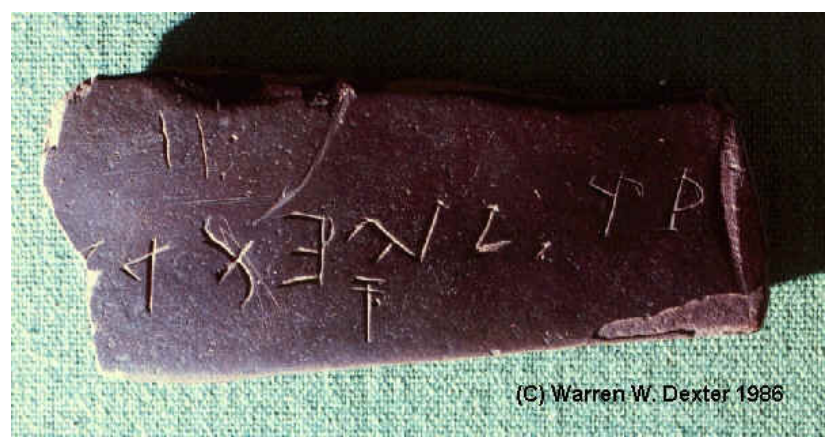

2.3 The Bat Creek Stone 
Other artifacts, discovered over the course of the $20^{\text {th }}$ century, support a link between the Melungeons and the Lost Tribe of Isreal. One such find, a stone with Phoenician inscription, was unearthed by Manfred Metcalf in Fort Benning, Georgia in 1966. While many of these regions have a high Melungeon population and the links seemingly give some support to a Melungeon/ Lost Tribe Link, the actuality of this connection is vague at best and there is not enough evidence to support the theory. In all likelihood, later settlers simply lost the coins that were found and Phoenician inscriptions could have been made in subsequent years as well.

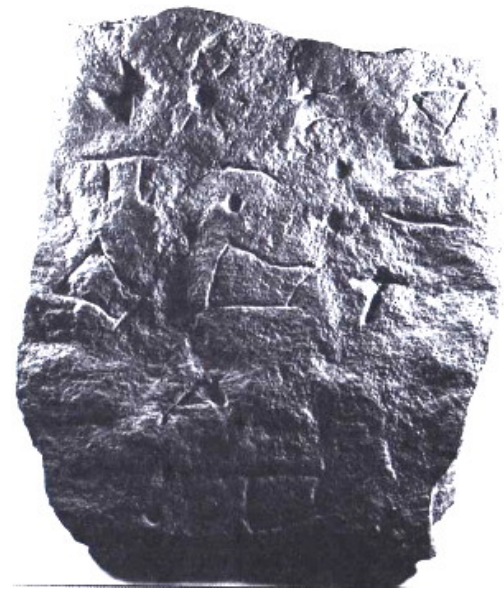

2.4 The Metcalf Stone

Another popular explanation for the origins of the Melungeon race is that they are descendent from Phoenicians or Carthaginians. This theory would explain the race's physical appearance: olive skin, curled hair, and dark eyes. This North African, Moor, and Arabic heritage would also account for the fact that 
Melungeons were originally deemed "free people of color" or a minority by courts of law in the late $19^{\text {th }}$ and early $20^{\text {th }}$ centuries.

Yet another theory returns to the notion that they are of Portuguese or Spanish descent. In the year 1540, Spaniards under the leadership of Hernando De Soto first visited the interior, mountainous regions of Western Virginia and Northern Tennessee, areas with a large Melungeon populous. Theories state that his party traveled from northwestern North Carolina through Tennessee and then back down south to Alabama and Mississippi. Oral history claims that some of these explorers intermingled with Native Americans and stayed in the area as settlers.

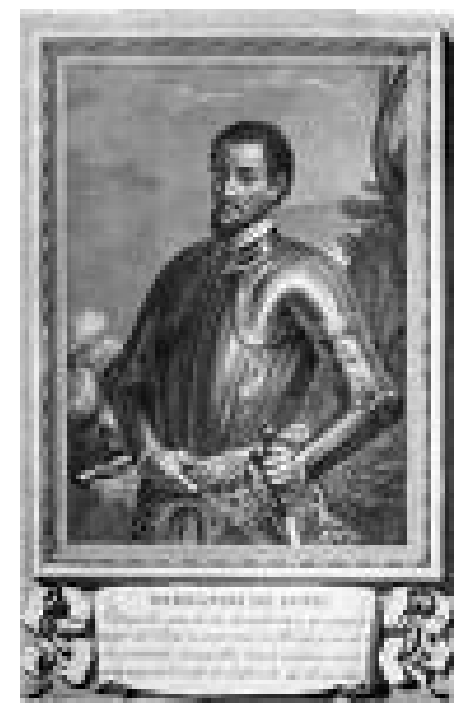

2.5 Hernando De Soto

Other legends tell of shipwrecked sailors on the coast the Carolinas, holdouts from the Duke of Braganza's fleet who left to establish colonies on the Atlantic seaboard and were never heard from again. Early Melungeons even 
described themselves as Portuguese to explain their darker skin and avoid being labeled as Free People of Color or Negro on state census records.

\section{The Legal Definition of Melungeons}

In 1872, a young, inexperienced attorney named Lewis Shepherd won a court case using the theory that Melungeons were related to Phoenicians and Carthaginians. This landmark case set precedent for the Melungeons' future dealings with the American judicial system. Shepherd's task was that of determining the origin of his client's descent. As the daughter of a Melungeon mother and a white father, his client, whose name is never mentioned in the case documents, was in danger of losing any claim to her rightful inheritance due to the color of her skin under Tennessee’s miscegenation law.

The details leading up to the case read like a mix between Great Expectations and The Young and the Restless. The girl's Melungeon mother had died during childbirth which led to her father's decline from shock into insanity. The girl was then sent to live with an Aunt Betsy in Illinois. The family Bible, one of the original documents used for tracking the births of children and deaths of family members, was sent along with her, and she was all but forgotten by the family with the exception of one of her father's friends, Mr. Samuel Williams.

After the father's mental health continued to decline, his estate was managed by a Mr. Foust. In an attempt to gain ownership of the man's land, his two half sisters and the children of a third deceased half sister filed a lawsuit 
against the guardian to acquire their half brother's property and holdings. Williams informed the girl, who was now fifteen years old, and they proceeded to file a countersuit as rightful heir to her father’s estate. Upon producing the Bible with the date of birth and record of her age, as well as the original marriage license of her parents, it was evident that the girl was indeed the daughter and rightful heir to her father's holdings. While the story should have stopped here, the true court case ironically had just begun. The girl’s race was now called into question by relatives believing she should not be allowed to inherit her own father's property or finances.

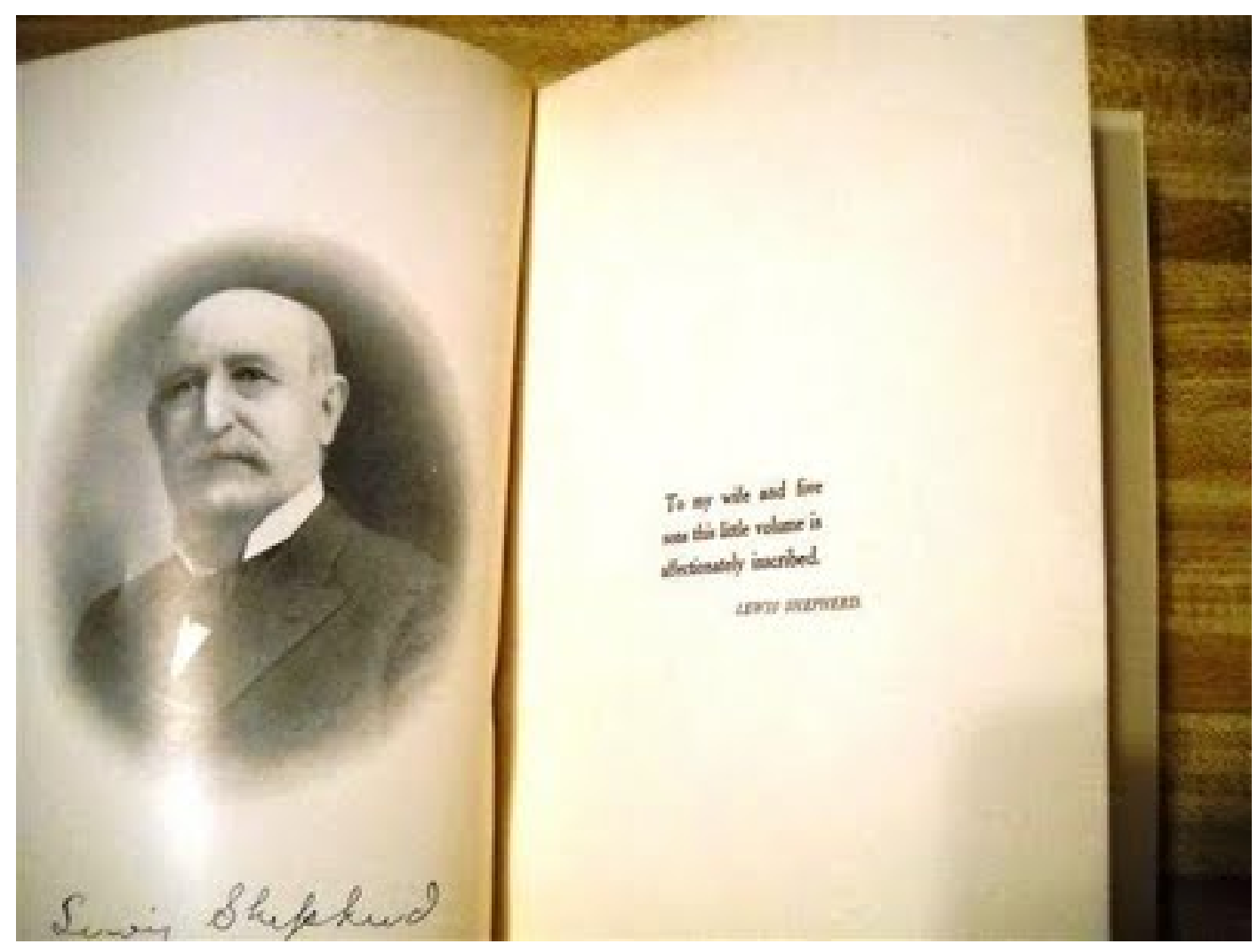

2.6 Lewis Shepherd’s Memoirs 
While the first part of the trial seemed Dickensian in nature, what followed in determining the girl's right to her father's estate is straight out of Shakespeare. The prosecution brought in African American defendants to swear to the kinked hair and dark skin of the young defendant and her whole family. It became apparent to all present that these allegations were fabricated when the girl pulled the hairpin from off of her head and let her thick, straight, black hair, some four feet in length, hang well past her waist. She was even asked to cut a piece off and attach it to her deposition, like some pound of flesh, as proof that the prosecution's main argument was a lie.

Shepherd went on to offer her Carthaginian and Phoenician ancestry as an explanation for the girl's dark complexion, even describing the women who gave their long black hair as material for the ropes that tethered war ships to the port. In his recounting, a great number of these Carthaginian/ Phoenician ancestors migrated to the coast of Carolina during the Revolutionary War period, where they were systematically oppressed and deemed free Negroes. This explanation, along with the fact that the girl's father had voted in elections, testified in court, and served as a soldier in the War of 1812 -- all actions prohibited to blacks during that time - served as the final support necessary for a winning verdict on the part of the defense. The fairy tale ending to this case acknowledged the girl as the heir apparent to her father's estate, awarded her funding for her education, and also gave the lawyer an unheard of $\$ 5,000$ for his hard won verdict. 


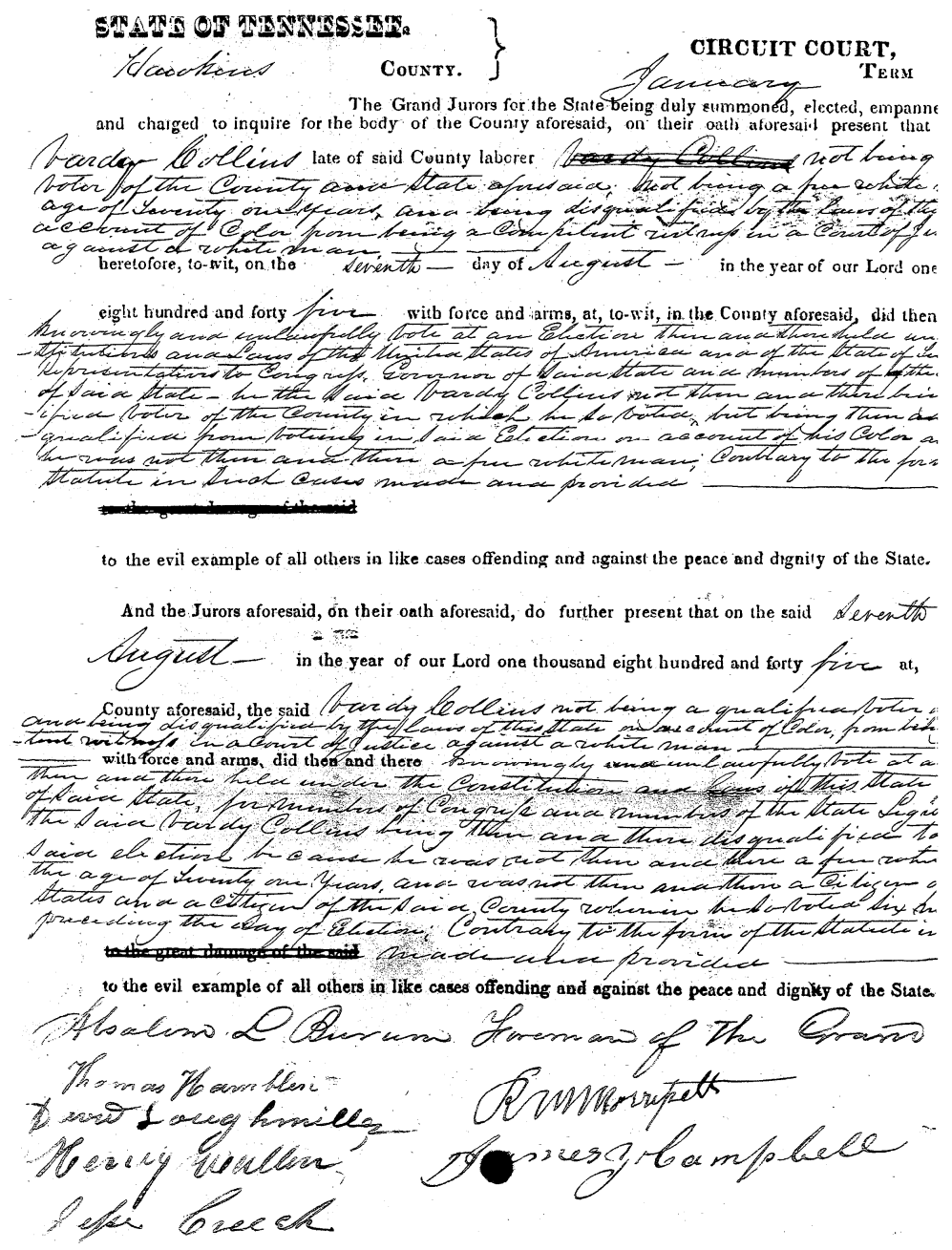

2.7 A sample document from Tennessee’s court system stripping legal rights from a Melungeon

\section{The Loss of Rights}

While the Shepherd case represented a major step towards equality for the

Melungeons, the group would face many more challenges in the struggle for their

rights. One such hurdle came in the early 1930’s when Walter Plecker, president of

Virginia’s Bureau of Vital Statistics, warned: “There is a danger of the ultimate

disappearance of the white race in Virginia, and the country, and the substitution 
therefore of another brown skin, as has occurred in every other country where the two races have lived together.”

Using the Virginia Racial Integrity Act of 1924 to classify Indians and Melungeons as "colored," he was able to deny these people their most basic civil rights through his state's system of segregation. In his letter to the Lee County Public Schools in 1930, Mr. Plecker adds:

Our office has had a great deal of trouble in reference to the persistence of a group of people living in that section known as "Melungeons," whose families came from Newman's Ridge, Tennessee. They are evidently of negro origin and are so recognized in Tennessee, but when they have come over into Virginia they have been trying to pass as white ...If we can get a statement that the School Board refused them admittance into the white schools, we can use that as one of the grounds upon which we would refuse to classify them as white.

Throughout the $19^{\text {th }}$ and $20^{\text {th }}$ centuries, Melungeons had their land, their social status, their civil liberties, and their dignity stripped away from them. An excerpt from the 1889 American Anthropologist article by Dr. Swan Burnett sums up the general feeling about Melungeons in the late $19^{\text {th }}$ century:

Legends of the Melungeons I first heard at my father's knee as a child in the mountains of Eastern Tennessee, and the name had such a ponderous and inhuman sound as to associate them in my mind with the giants and ogres of the wonder tales...I shrank under the bedclothes trembling with a fear that was almost an expectation that one of these huge creatures would come down the chimney with a rush, seize me with his dragon-like arms, and carry me off to his cave in the mountains, there to devour me piecemeal.

It is no wonder that descendants of Melungeon heritage sought to hide their lineage. Many families changed their surnames to disassociate themselves with the 
common Melungeon monikers of Collins, Mullins, Goins, etc. Mothers kept their daughters in long sleeves for the whole summer, away from the sun that threatened to darken their already olive complexions. Some Melungeon families even stopped recording births in the household Bible in an attempt to disconnect themselves from their true roots. According to Burnett,

The current belief was that they were a mixture of white, Indian, and Negro. As a rule, they do not stand very high in the community, and their reputation for honesty and truthfulness is not to be envied. In this, however, there are said to be individual exceptions...It is perhaps characteristic of them that, since a revenue tax has been placed by the Government on the manufacture of spirituous liquors, these people have been engaged largely in illicit distilling.

\section{Early Writings on the Melungeons}

Will Allen Dromgoole penned some of the earliest known writings about Melungeons at the turn of the $19^{\text {th }}$ Century. Although she was an outsider from the North, she claimed to have lived amongst the Melungeons of Newman's Ridge for several months documenting their way of life. The findings from her field research were published in a series of articles, and they consisted of jumbled half-truths and unsubstantiated theories. She helped to further stigmatize the already outcast Melungeons. In her article, "Land of the Malungeons," which first appeared in the Nashville Sunday American, August 31, 1890, she wrote the following description:

They are exceedingly lazy. They live from hand to mouth and in hovels too filthy for any human being. They do not cultivate the soil at all. A tobacco patch and an orchard is the end and aim of their aspirations. I never saw such orchards, apples and apples and apples, peaches and peaches and peaches, and soon it will be brandy and brandy and brandy. They all drink, men, women and children, and they are all distillers; that is, the work of distilling is not confined to the men. Indeed, the women are the burden- 
bearers in every sense. They cook, wash, dig, hoe, cut wood, gather the fruit, strip the tobacco and help with the stills. There is not so much distilling now among them as there was a few years back. Uncle Sam set his hounds upon their trail, and now they are more careful of the requirement of the federal law at all events, as their miserable little doggeries, dotted here and there, go to prove.

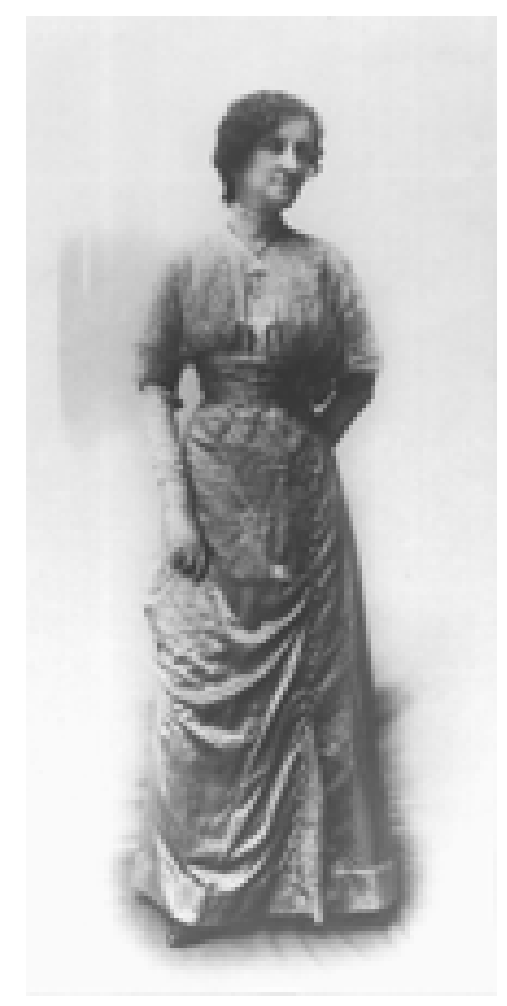

2.8 Will Allen Dromgoole circa 1890

For the better part of the $20^{\text {th }}$ Century, Melungeons remained as mysterious and misunderstood to the world at large as they were to Miss Dromgoole in 1890. They kept to themselves in less populated mountainous regions of Southwest Virginia and Eastern Tennessee. They guarded their privacy, held their secrets close to their chest, and at times even denied their Melungeon heritage in order to fit into society that had subjugated and maligned them for so many years. 
As people of Melungeon descent continued to be systematically persecuted, they began to operate outside of society's confines. They began to feel more comfortable as fringe dwellers: counterfeiters and bootleggers. Tales of Melungeons like Brandy Jack Mullins and Mahala Mullins have been told and retold so many times over the years that they have evolved to a mythical status. 


\section{My Melungeon Roots}

\section{My Initial Interest in Melungeons}

The first time I ever recall discussing the Melungeons was during a cookout at my Aunt Iva and Uncle Harold's house in Powhatan, Virginia. It was the summer of 1992, and I was about to graduate from James Madison University with a Bachelor's Degree in English and Anthropology. As always at our family gatherings, after everyone’s belly was filled with southern cooking and the light began to fade to dusk, it was time to sit back and tell stories, both old and new. My parents were there with my grandmother and various aunts and uncles, along with a cousin from Wise, Virginia, Richard Kennedy.

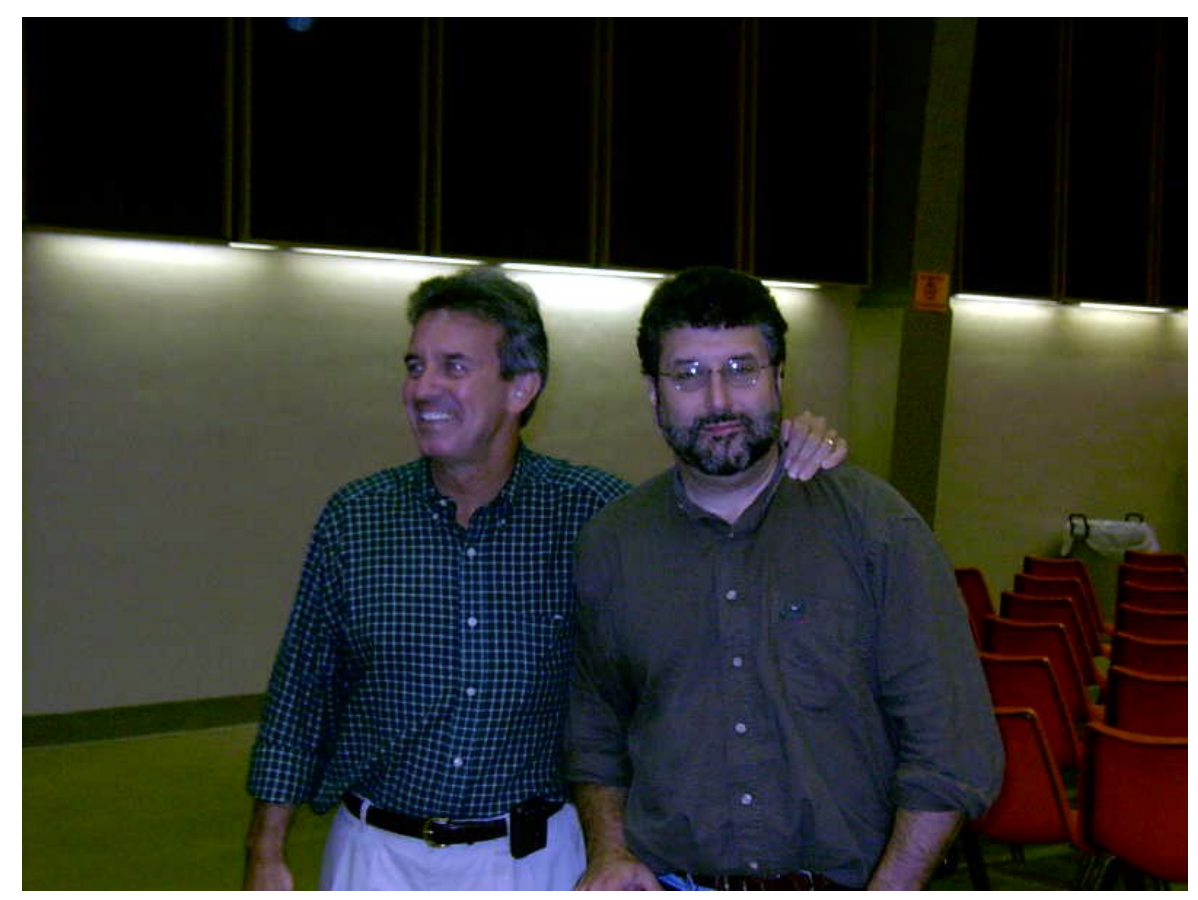

3.1 Brent and Richard Kennedy 
The last time I had seen Richie was more than a decade earlier, and even then it had been a brief meeting at N.B. Kennedy’s house in Wise. I remembered him climbing a tree and telling jokes and that was about it. We sat around the grill after dinner to tell stories, just as storytellers have done for countless centuries around fire pits. We talked about our various lives and plans, but it took a distinct twist when the topic of conversation shifted to Richie’s brother Brent, commonly referred to as Winky by our family. A few years earlier, Brent had been diagnosed with a rare blood disease (Erythema Nodosum Sarcoidosis) primarily found in people of Middle-Eastern or Mediterranean descent. While this disease can result in debilitation, paralysis, blindness, and even death, Brent's case of Sarcoidosis went into remission after six months, and he made a rapid recovery from the illness.

At this time, Brent was in the process of writing a series of articles on his near death experience, which would later be compiled into his book The Melungeons: The Resurrection of a Proud People. As a fledgling writer and anthropologist, I was captivated by the idea of historical research stemming from such a deeply personal experience as an illness. Another aspect of Brent's Melungeon research that piqued my interest was his discovery that our ancestors were not the Germanic/ Scotch-Irish settlers I had always thought them to be, since I assumed with names like Kennedy and Kiser that my family was of European descent.

Speaking of Napolean Bonaparte Kennedy, Brent says, “[N.B.] was himself half Melungeon. A short, powerfully built man with black hair, dark brown eyes, 
and an olive complexion. He had been on his own since he was eleven, having had a terrible falling out with his stepmother... For a while in his teens he did motorcycle stunts and other unsavory tasks for county fairs to earn his meals...By hook or crook, N.B. Kennedy amassed what was a fortune for his time... People were afraid of him, and probably with good reason. He once paid a fine - in advance - for beating up a man who had offended him. He had henchmen, hired thugs, who would look after his interests and he despised anyone that he felt looked down on him.”

While N.B. wasn’t your typical Melungeon, pushed back into the hills and ostracized, he still operated outside of the law in both his family relations and business affairs. He owned race horses and ran a lucrative business servicing jukeboxes and pinball machines in roadhouse bars and filling stations. His entire life was shrouded by a veil of secrecy, some for the purpose of his illegal business dealings with gambling and loan sharking, but much of the mystery surrounding his past stemmed from the greatest secret of all: his Melungeon heritage.

\section{Reconnecting with the Past}

Although I had passed through Wise, Virginia on my way to Kentucky in 1991, I didn’t really explore the town again for another five years. This next visit served as a pilgrimage of sorts to rediscover my roots and begin to gather the voices and stories that had been beckoning to me for so long. During the summer of 1997, I was working as a raft guide in the New River Gorge of West Virginia. My daily trip down the river led me past more than a dozen abandoned coal mines, 
once thriving little cities, now ghost towns. I knew that my relatives had been miners; one had even died in a coal mine attempting to rescue a co-worker. I began researching the history of mining, and my search brought me back to the trail of the Melungeons, many of whom worked in or owned mines, both coal and silver.

Since the New River Gorge was only an hour or so away from Wise, I decided to reconnect with the people and places that I hadn’t truly seen since my childhood. I dropped in unannounced to my Uncle Brent Sr's service station. I smoked cigars and ate lunch with a man I had not seen in over twenty years. This incident alone made me realize the strength of shared blood and memory, especially among southern mountain folk. I went back to the house that my great grandfather had lived in, the one where I remembered recording stories as a child, and even though it was inhabited by strangers now, they let me tour this monument from my past that seemed so incredibly huge when I was young. It is amazing what perspective, be it time, age, or point of view, can do to a memory, an image from the past.

My final stop on this homecoming of sorts was at my Grandfather's grave, the last place I remembered visiting for his funeral twenty years earlier. I remembered walking around the tall grass and towering grey stones wondering how I was supposed to react to the sadness that surrounded me. When no one was looking, I crouched at the side of his grave and dug with my tiny hands in the dirt where stone met earth. I pulled a 1776-1976 Quarter out of my pocket and slid it down in the cold ground. To this day, I'm still not sure why. 


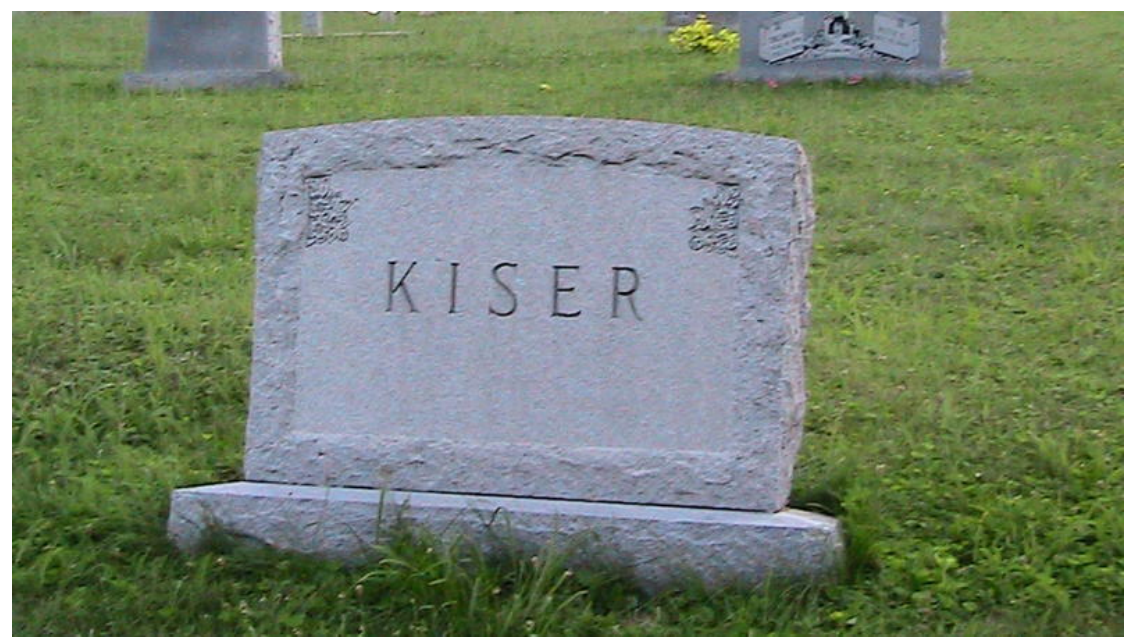

3.2 William Jennings Kiser’s Headstone

Revisiting these iconic places from my past rekindled a desire to explore the voices and stories of my relatives. Even though I was only a child when I heard them for the first time, so much of the family’s history loomed large in my life, as if I had my own personal folklore or mythology. During this visit I got a copy of Brent's newly published book. It not only included family tales that were familiar to me, but it also gave detailed background on the real lives of the people who, up until this point, were merely two-dimensional characters in the recesses of my memory.

\section{Fact Inspires Fiction}

As I sit in my office typing these words, family history surrounds me. My great grandfather with white fedora stands beside his prize thoroughbred Corktown at the Riverdowns. News clips with words of mining disasters and wartime valor line the wall. To my right stretch the branches of relatives like Andrew Jackson 
Mullins, Abednego Kiser, Lucinda 'Sin” Mullins, and other names larger than time itself. The 1997 publication of Brent's book brought to my attention a connection between my family and several famous underground figures in Appalachian folklore and history such as Brandy Jack Mullins the counterfeiter and Mahala Mullins the bootlegger. Using his family tree from the book, I can trace my roots back as follows:

$$
\begin{aligned}
& \text { Andrew Jackson "Brandy Jack" Mullins + }+ \text { Polly Anna Mullins } \\
& \text { (1824-1917) } \\
& \text { W.S. Powers } \\
& \text { (?) } \\
& +\quad \text { Lucinda “Sin” Mullins } \\
& \text { (1838-1864) } \\
& \text { David Kennedy } \\
& \text { (1880-1859) } \\
& +\quad \text { Ida Powers } \\
& \text { (1884-1903) } \\
& \text { Napolean Bonaparte Kennedy } \\
& \text { (1903-1986)1. } \\
& +\quad \text { Tessie Colley } \\
& \text { (1899-1988) } \\
& \text { William Jennings Kiser } \\
& +\quad \text { Ruby Claire Kennedy } \\
& \text { (1927- 1977) } \\
& \text { (1929- ) ) } \\
& \left.\begin{array}{ccc}
\text { Ronald Everett Horton } & + & \text { Sandra Joyce Kiser } \\
(1947-\quad) & (1950-
\end{array}\right) \\
& \text { (1970- ) }
\end{aligned}
$$

\subsection{Brandy Jack Mullins Family Tree}

While this newfound information set me off on the trail of stories, both historical and mythological, it also motivated my father to begin compiling family trees and timelines, one of which is staring back at me now from the wall of my office. Through my father's research on the Kennedy family's history, I can trace 
my ancestors back over the course of time to the early 1700's. Our heritage can be followed through towns like Wise and Caney Ridge, Virginia, Sneedville and Newman's Ridge, Tennessee. Our relatives made their homes in the ridges, hills, and hollers on the outskirts of small southern, mountain communities. One fact that remains true in the gathering of a family story is this: there are no single truths but rather a variety of different interpretations that form a collective version of what occurred. 
Brandy Jack Mullins

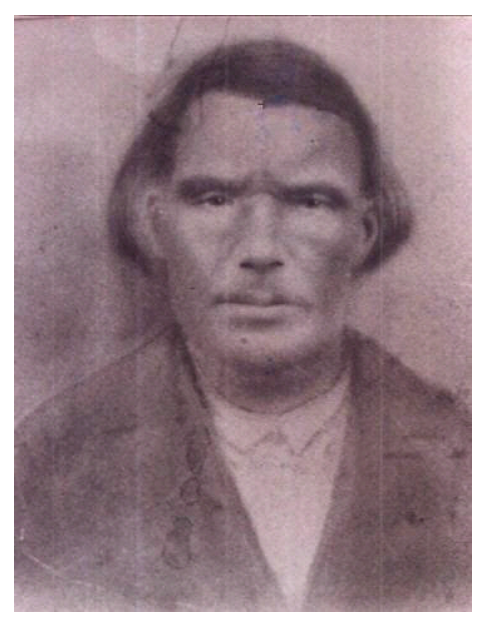

4.1 Brandy Jack Mullins

Back in the early days, names had meaning. Words held more weight in those days; they said something about the speaker, the subject. And it is said that Brandy Jack got his name from the liquor that he made from a local Reverend's fallen ground apples. Although the man would chase him off during the daytime, he would sweep the orchard clean under cover of the night.

Several Mullins family descendants formed a group dedicated to preserving the history of their ancestors called The Order of the Silver Apple. They printed a book dedicated to him entitled Brandy Jack and Beyond: A Mullins Family History. This remarkably detailed publication includes an abundance of stories related to their most famous relative. In later years, he acquired his own apple orchard that he would use to make liquor in his still on the same land. His granddaughter Phoebe Mullins Ely tells how, upon visiting his still on two separate occasions and finding 
his mash stolen, he searched the area and found not human footprints but bear tracks. Picking up an axe, he followed the animal's prints into the woods. "He hadn’t gone very far until he saw the tracks weaving from side to side, staggering around... He found the bear lying on his back with a stick throwing it up and catching it: playing and having a good time. When he went up to it, it was so drunk that it couldn’t get up and fight and he killed it with his ax.”

Maybe this is all a lie. I read different versions of the same story, each with its own personal bent. I can trace Brandy Jack’s name on a series of lines, handwritten ink on paper that hangs on my office wall. Sometimes I think of the hand that wrote them, and I want to cry for fear of things to come. I picture my father, sitting alone at the kitchen table writing names on a family tree pausing from time to time. I can lose myself in these thoughts of this man, whom I love but don’t really know, moving his hand steadily over the paper, writing words that mean so much and nothing at all. I think of the blessings and curses that he has passed to me. I think and think to a point beyond clarity. I could cripple myself this way, with empathy and indifference.

Brandy Jack Mullins didn't trouble himself with thinking too much. Even if he did tend towards reflection from time to time, he bore that curse like a good southerner, with silence and a certain dignity. Born February 28, 1824 in Kentucky, Andrew Jackson Mullins would walk this earth for close to a century. Times were surely harder in those days, and the average life span was shorter, yet 
this great, great, great, great, distant relative of mine would see the turning of a century and then some.

Looking at the picture in a book of family history that bears his name, I can read stories in the lines on his face. The picture, a grainy cross between a mug shot and a family portrait, tells its own tale. Dark, weathered skin, high cheekbones, fixed stare behind dark eyes... his hair, pushed back behind the ears, reaches neck length; it frames his hardened face from upper lip to furrowed brow. In this picture, he can’t be much older than I am now, but already he has lived a lifetime. I search for some familiarity, binding me to this man whose blood flows through my veins. But I come up feeling unworthy. In the face of history, I see myself as the weakest link at times, destined to record the stories of greatness and excess from my own comfortable place in the here and now.

\section{Family Life}

Over the course of his 93 years of life, Brandy Jack was married four times and he had twenty children, the last of whom lived until 1989, the year I left for college. In 1864, his first wife, Mary Pollyanna Mullins, died in childbirth at the age of 41. He married Phoebe Vance a year later, and she lived until 1884, dying from scrofula or tuberculosis of the neck. He married his next wife, Sarah Mullins, in 1887, but the union had lasted only three years when, in 1890, she also died of tuberculosis at the age of 27.

What did people think back then of one wife dying and another taking her place so soon? Nothing records these feelings, just names and dates based on 
written facts and public record. His fourth and final marriage outlasted Brandy Jack. He died in 1917 of old age in his $94^{\text {th }}$ year. He had children whose names tell their own dark tales, Servillas and Lucindas -- called "Sin" for short -- Sampsons and Noahs with all the hope of history behind them. Each finely written name is on a line to the right of a line delineating time in the form of a tree. Trees grow, leaves fall, family names like roots, like branches, bleed sap, sticking the sins and salvations of past to now.

\section{Brandy Jack the Counterfeiter}

Much lore surrounds the very name Brandy Jack. Even the connotation of Brandy at the time was synonymous with illicit activity. His was not a name associated with mere whiskey, but the more sophisticated and coveted brandy. The area of Caney Ridge, Virginia was a perfect setting for his exploits. The region was isolated, located miles away from town in the winding hills and hollows of the Blue Ridge Mountains. Many Melungeon families lived on Caney Ridge, some by choice and others because it was well known that their kind was unwelcome in town. This area's remote geography set it apart from the prying eyes of town, and the area's inhabitants were in no hurry to provide information about their tight knit community. Melungeons, already maligned by the general populace, were mistrustful of lawmen with their false accusations and legislators with their unjust laws. It also didn't help that the idea of mountain justice during these times often ended in a verdict at the barrel end of a shotgun. 
Named Andrew Jackson at birth, Brandy Jack soon adopted his father Sol Mullin's art of counterfeiting and metallurgy. The history behind Brandy Jack's work as a counterfeiter is one of mystery and contradiction. Some of the more detailed stories come from family members recounting generations of oral tradition.

Southwest Virginia historian Dr. Curtis Kennedy gives one more factual account of both Sol and Brandy Jack’s work as counterfeiters and dispels some myths about the origin of their materials. Sol made coins of lesser quality than Brandy Jack went on to create, as he took one coin, melted it down, and then turned it into two or three coins, thus adulterating or diluting the quality of the coin. When Brandy Jack apprenticed under Sol to learn the family business, he introduced Bakers Metal, a silver substitute, as a cheap way to make the coins appear of higher quality. Kennedy describes Brandy Jack’s coins as containing no silver. His successor Paw John Kennedy called it “...the worst queer [currency] I ever saw.” This academic account directly contrasts other oral stories which read like myth or tall tale.

Depending on the family member relaying the story, details change. The nature of his livelihood made stories about him fit for certain audiences only, as information in the wrong hands could lead to trouble. One of his grandchildren, Frankie Salyer Mullins, spoke about his grandfather as "smart enough to make the molds for those beautiful and perfect silver dollars... He was found out... and sent off but they wanted the molds to see what they looked like. His was better than the 
governments and had more silver in it. They got him for defrauding the government.”

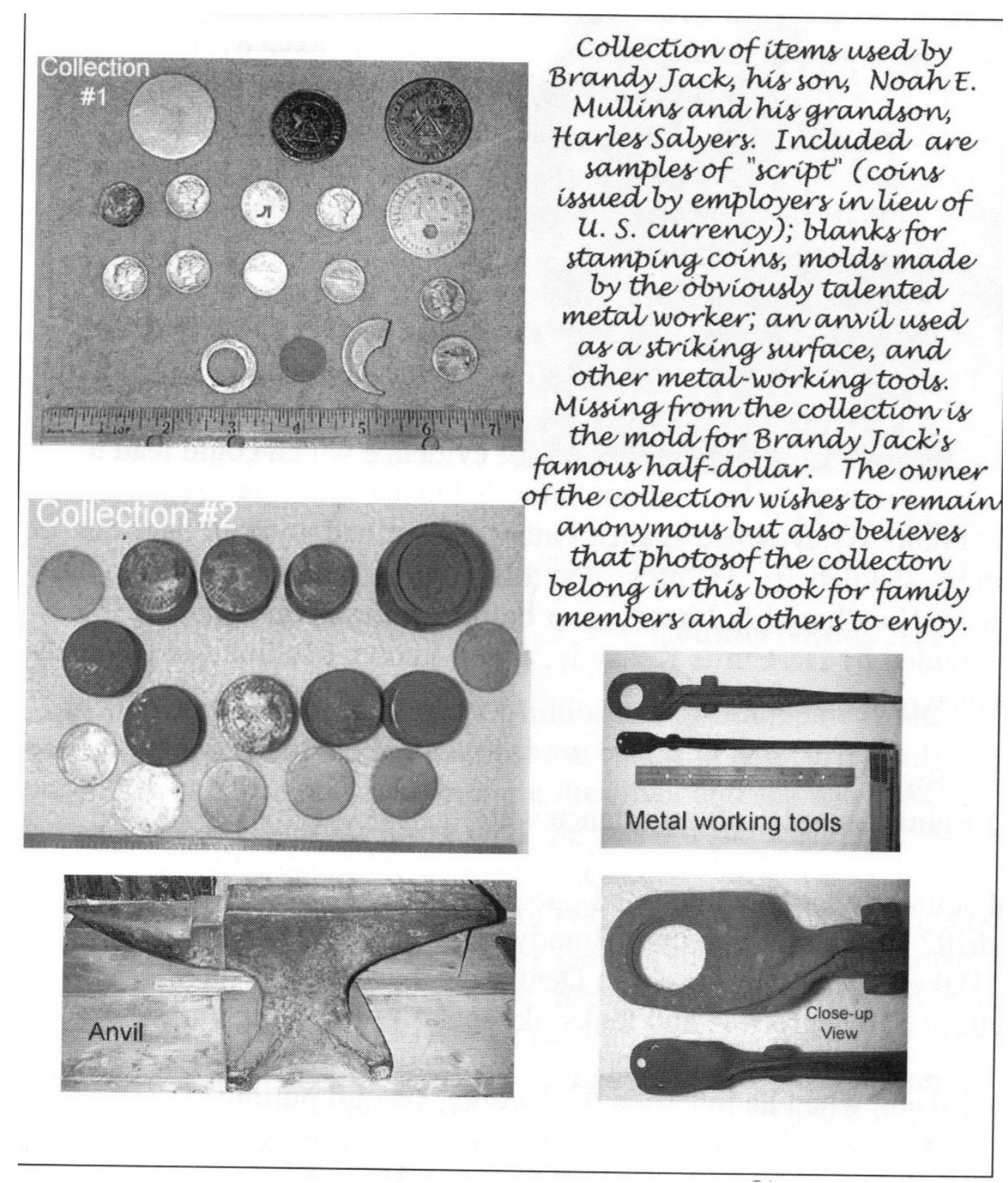

4.2 Samples of Brandy Jack’s counterfeiting tools and coins that he made 
Rumor has it that Brandy Jack had discovered his own silver mine where he harvested the metal necessary to ply his art. Another story tells of an old woman -- or man masquerading as a woman -- all dressed in black, riding the metal in on a mule from Kentucky. The fabled mine remains hidden to this day.

Son Scott Mullins shares a sparse story of his father’s arrest. A vagrant named Joe Sire Hill who was staying at the house betrayed Brandy Jack by filling his flint-lock rifle's muzzle with clay so that he couldn't defend himself. Later that evening, a knock came at the door with news of a man with a broken leg who needed a place to rest while his friend went to a nearby town to fetch a doctor. When Brandy Jack opened his door to the stranger's request, he was ambushed by U.S. Marshal Lark Selsor, five of his deputized men, and Hill himself. Although he put up a respectable fight, Brandy Jack was eventually cuffed and taken away to jail in Abington, VA.

After sentencing, Brandy Jack served six years and nine months of a supposed six year sentence, adding to the family’s general feeling that he was wrongly imprisoned. His unfair arrest, his mistreatment in prison, and the death of his brother, Andy Mullins, who was also incarcerated on the same charge, weighed heavy on Brandy Jack. He spoke about them a great deal in his later years.

\section{Related Myths and Tall Tales}

Relative Jarvie Mullins tells the story of Lark Selsor, the U.S. marshal who arrested Brandy Jack, from the first-hand account of a local ginseng hunter, Daniel Ramey. Allegedly, Ramey found Selsor's dead horse in an area called the 
Flatwoods, roughly four miles southeast of Coeburn, VA. As he was trying to knock off the horse's shoes, Daniel heard a voice that spoke to him. Here the details are ill-defined, but the voice said something to Daniel that set him running towards his home in Coeburn. When he arrived home and told people about the dead horse and the mysterious voice he had heard, they asked him how he crossed the Clinch River on foot. Daniel said that when he reached the Clinch River, “There warn’t no river there.”

After the story of the dead horse, a search was conducted for Lark Selsor, and his body was found buried in a hollow log not far from the horse. Brandy Jack was still in prison at this time. When told of the marshal's death, he swore to knowing nothing of the matter, but oral history tells a different tale. After his death, rumors surfaced of the marshal's cruelty. One famous story has him giving a silver dollar to the daughter of a man whose house he visited and stayed at on his travels. Supposedly he took the dollar back the next day and arrested the man for counterfeiting. It's also rumored that before he left home the last time before his death, his wife's final ironic words were, "I wished the buzzards would pick his eyes out before he returned.”

\section{Sorting Fact From Fiction}

A formal investigation was launched into the Marshal's death, but the tightknit community of Caney Ridge protects its own, so eventually the search for the man's killer or killers was disbanded. No one will truly know the facts surrounding the death of Lark Selsor. Rumor becomes oral history though, and once recorded, 
it is almost as good as fact. Landmarks are associated with the death of the marshal; one has since been deemed Selsor Rock. Supposedly when Lark was shot in the head, he fell from his horse striking his head on a rock beside the road, leaving a blood streak and a lock of his black hair. This folk tale leads one to wonder just how many landmarks defined by a surname have such sinister origins.

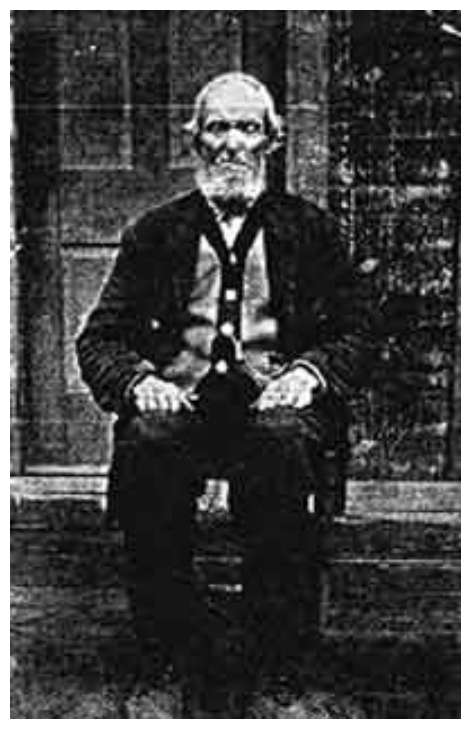

4.3 An elderly Brandy Jack

Scott Mullins, a relative of Brandy Jack, wrote of his search in 1952 for the rock in the Flatwoods near Jaybird Branch some four miles outside of Coeburn. Scott Mullins located the rock with the help of Mr. Stidham who lived about 150 yards from the spot. They then carved the date of the man's death in his rock before leaving. But anyone present at the scene is long dead, and by now, even the oral traditions surrounding his demise have become diluted by countless years of retelling. 
Regardless of the fact that he was in prison at the time, Brandy Jack Mullins has always been held responsible for the man's death. Whether it was his relatives, accomplices, or other unknown persons sympathetic to the counterfeiter's imprisonment, the lawman’s death remains another notch in Brandy Jack’s belt. After his release from prison in 1882, he moved to Caney Ridge with his second wife, Phoebe Vance Mullins. He stayed there either living a straight and narrow existence or at least staying one step ahead of the law until his death on April 9, 1917. His molds, tools, and stock of silver were never found. 


\section{Tracing the Path of Brandy Jack}

\section{A Trip to Caney Ridge}

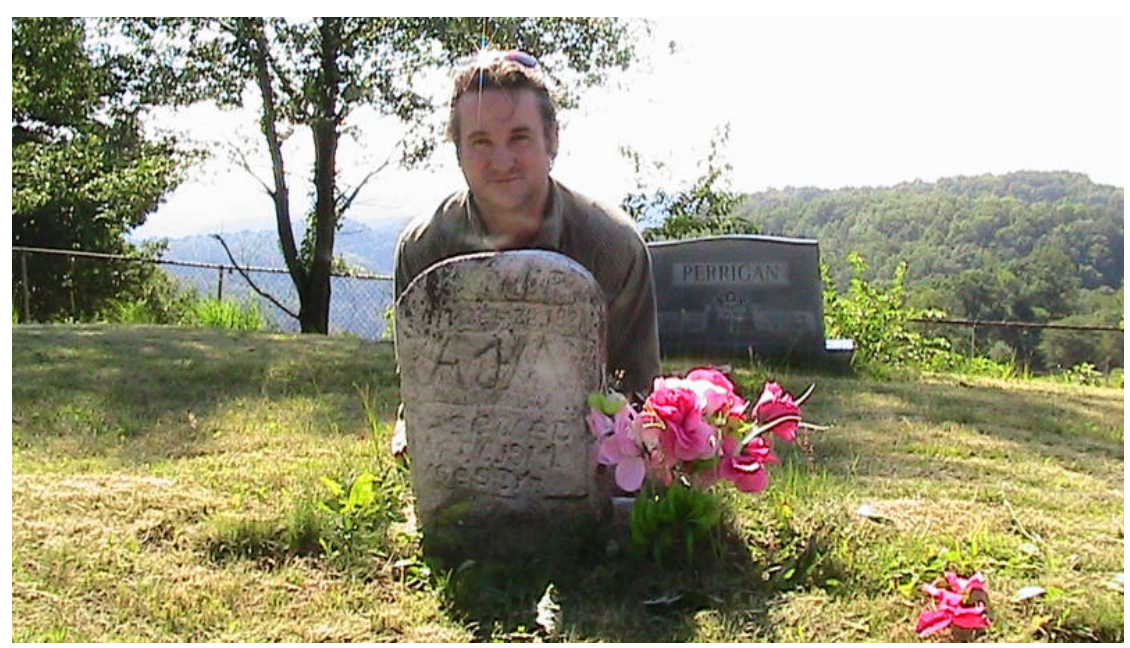

5.1 The author standing in the shadow of Brandy Jack’s grave

In the summer of 2009, I drove across the country to my parents' house in

Jonas Ridge, North Carolina to trace my family’s Melungeon history firsthand by visiting some of the areas that I had been researching. Since Brandy Jack had spent the majority of his life on Caney Ridge, a small mountain community just outside of Pound, Virginia, I chose this area as one of my main destinations to gain an understanding of Melungeon life during his era.

My mother and I started our journey to Caney Ridge early one June morning; we navigated our way on back roads through Kingsport, Tennessee to the town of Wise, her early childhood home. There at my Uncle Brent's service station we met up with my cousin, Karen Kennedy, a stout, salt and peppered mountain 
woman. She is the daughter of Kenneth Kennedy, my Great Grandfather N.B. Kennedy's oldest son who died in a coal mining accident when Karen was just a small child. Her resemblance to my Aunt Iva was eerie, as Iva had recently passed away; I felt as if I knew Karen even though we had never formally met before.

At Brent's station, we sat in the office getting re-acquainted with one another. This was the third time that I can remember ever meeting the man, though I know I must have spent time around him as a kid. I visited Brent before on my first trip back to Wise in 1997, and then again in 2006 with my mother. On that second trip, he took us to an area just a few miles outside of Wise called “The Hurricane,” with a similar history to Caney Ridge: mountainous land on the outskirts of town where people of Melungeon heritage settled in the late 1700's to early 1800’s. Even the names of these places paint a vivid image in the listener's mind; they sound distant, exotic, and somewhat dangerous.

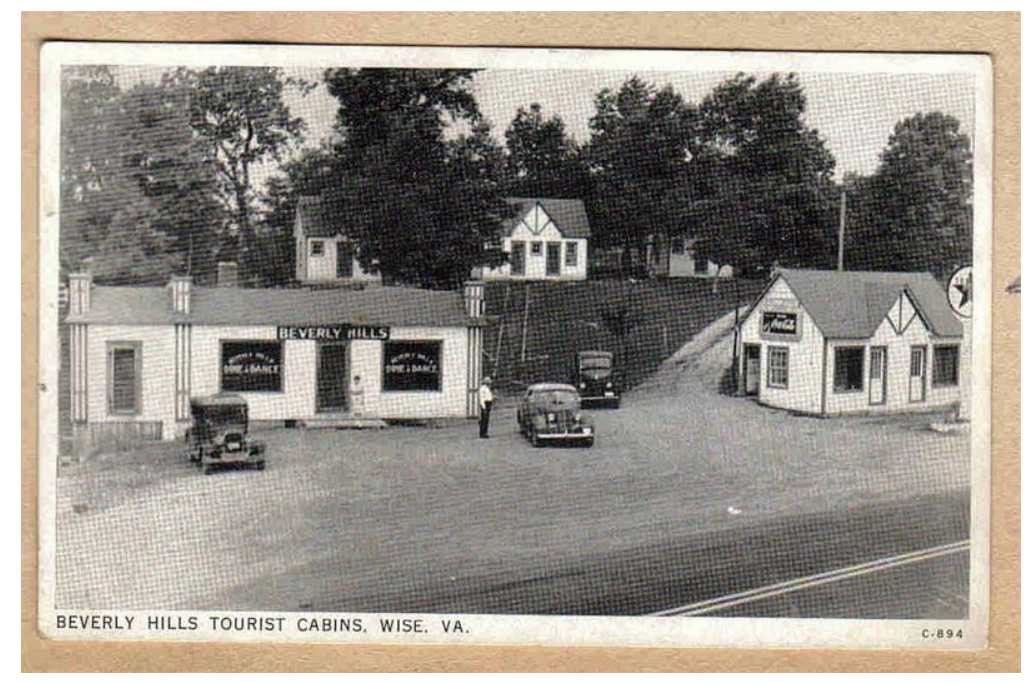

5.2 Site of Brent Kennedy Sr’s service station, formerly Beverly Hills Tourist Cabins 
Karen was our ticket onto Caney Ridge, which is not the kind of place you visit without an invitation. In her slow, southern drawl, she warned us about the area’s reputation. "You don't come here unless you have somebody to welcome you. They take care of their own up here and don’t take kindly to strangers poking around.” This ridge is a sanctuary for Karen, a place where she has lived much of her life and plans to spend eternity. She already has a headstone at the family cemetery right next to her first dog. While Karen dwells in the world of people and even has children of her own, she seems more comfortable with the utter honesty and unconditional love of dogs and cats.

5.3 Brent Kennedy Sr., Sandy Kiser, and Karen Kennedy in front of Kennedy Auto Sales

My mother hopped in Karen's well-used mini-van filled with aging animals, steadily panting against the early summer heat. Early on, I witnessed Karen’s even-tempered mix of wild eccentricity and big-heartedness as she doused the 
nearly unresponsive animals with cold water and ice to fend off the impending heat of mid-day.

Wheeling out of Kennedy Auto Sales and onto the main street of Wise, I have to push the pedal to the floor in a vain attempt to keep up with my mother and cousin Karen on our ascent of Caney Ridge. The early summer breeze flows warm through my car window; this land, so familiar and foreign, cradles me in its lush, green, tattered arms. Though I have only been here sporadically over the past few decades, I somehow always feel closer to home when I see those Blue Ridge Mountains of Virginia.

In two days I will be thirty-nine years old, and I've been winding these back roads in some form or another for my entire life. On family trips I always knew that we were getting close to Wise when we crossed the Cumberland Gap and reached an overlook known as Gooseneck Bend, named for the tight turn in the road atop a high hill. It was always a landmark to me, a hint of something higher, greater, and wider. This vast black expanse of void with scattered lights below seemed infinite. My current drive up Caney Ridge, with its twists and hairpin turns, reminds me of that same feeling I got looking over the edge of Gooseneck Bend so many years ago.

Winding down these back mountain roads through towns with names like Coeburn and Pound, I press record on my video camera, place it precariously on the dashboard of my Subaru, point the lens out on the country road as it winds through hills and hollers. My narration starts sporadically, a mixture of directions 
and descriptions of landmarks and names. I think about the people who walked this earth before my time, wonder if their spirits still roam these hills.

This place that I am traveling towards is familiar to me only by name. I have never set foot on Caney Ridge before, but it is still a home to me. This hilly land is filled with the history of people who share my name, my blood, and my heritage. I have been driving and filming for at least fifteen minutes, navigating the countryside some ten miles outside of Wise. I think back to a time before paved roads and cars when people traveled on foot or by horse if they were lucky. From the top of this ridge, it would have taken even the fittest person the better part of half a day to reach Pound alone, and Wise would have been a few flat miles further. This remote, hilly terrain is the area where Brandy Jack Mullins chose to live the majority of his life.

\section{Meeting Ginger Senter: Caney Ridge Historian}

Our destination, after winding up the steep, paved switchbacks for what seemed like an eternity, is the home of Ginger Rose Senter. Like her relative Brandy Jack Mullins, Ginger has lived on Caney Ridge most of her life. She is also one of the main contributors of genealogical information and historical research for the Kennedy and Mullins families in Brandy Jack and Beyond: A Mullins Family History. Her knowledge of the people, places, and events surrounding Caney Ridge, Virginia is unsurpassed.

We meet Ginger on her sun porch to discuss our mutual relatives, her home, and how the two relate to the memoir I am writing. Like any good southern host, 
she has sugar cookies and sweet tea waiting for us when we arrive. Although she is several years older than my parents, Ginger’s vibrant smile and energetic nature give her an eternally youthful demeanor. The conversation is a bit forced to begin with, but soon the formality of strangers getting acquainted dissipates, and it feels as if we have known each other for years. Living far from home in a western city, I forget how hospitable and willing to help southerners can be. This is also my mother's first time on Caney Ridge, even though she spent part of her childhood in Wise. Karen stays behind at the house while Ginger drives my mother and me around the ridge.

Our first stop, right at the end of Ginger's driveway, is a one-room cabin that originally belonged to Brandy Jack’s second wife Phoebe Vance’s father, David. David Vance moved to the area in 1836, purchasing 1,100 acres atop Caney Ridge for the fabled price of one hog rifle. The entire house is scarcely larger than my living room. Generations of my distant family members were raised in the tiny confines of these four sturdy log walls. Although the cabin still consists of the original timber, it was moved in 1995 to its present spot from Ray Kennedy’s land roughly a mile away. The only condition imposed on Ginger and her husband James in moving the cabin from its original site was that it be kept intact for future generations to visit. While Brandy Jack never lived in the cabin himself, he and Phoebe did live some four miles away on Allen Creek.

We pull out of the driveway with Ginger at the wheel of her forest green Ford Explorer. I begin filming in the car as our local guide talks about the history 
of this place. She grew up here and has lived most of her life on the mountain top that her relatives settled close to two centuries earlier. Our next stop is a little Victorian house from the 1890s just a stone's throw down the road. Ginger tells us, “ This is where my brother lived up until he died.” She pauses for a moment. I can tell that she doesn't want to talk about her brother's death, at least not yet. She continues, “But a long time before that, this here was N.B. Kennedy’s Grandaddy’s house, that would be Forrest Kennedy." It is hard to imagine that the structure is even that old, as it has seen several renovations over the years. Like so many houses in these small southeastern mining towns, it most likely came from a Sears’ catalogue or the like, shipped on a train powered by the very coal that once filled these hills.

To the casual onlooker or visitor to Caney Ridge, the rich history of this area is all but invisible. Even as I search for clues of Brandy Jack's presence here, without Ginger’s regional knowledge and dedication to preserving her distant relative’s legacy, I would find myself virtually empty-handed. As I am walking back to her car, she points at an old millstone leaning against the side of the house, casually remarking, "Oh that right there, the old stone with a hole in the middle, they say that's an artifact from Brandy Jack’s day.” I wonder how many other items he had touched would remain hidden in plain sight were it not for Ginger’s historical commentary.

The next place we visit is the house N.B. Kennedy and his first wife, Tessie Colley, lived in before he moved to Wise. Like the Vance Cabin and Forrest 
Kennedy’s Victorian house, Ginger owns this place too. After N.B. left for Wise, Papaw Kennedy lived here as well. Although I remember a mamaw and papaw from childhood, they were great-grandparents on my Grandfather Kiser’s side, and they lived in the Hurricane on the other side of Wise. These names, mamaw for grandmother and papaw for grandfather, are regional anomalies used in rural Appalachia.

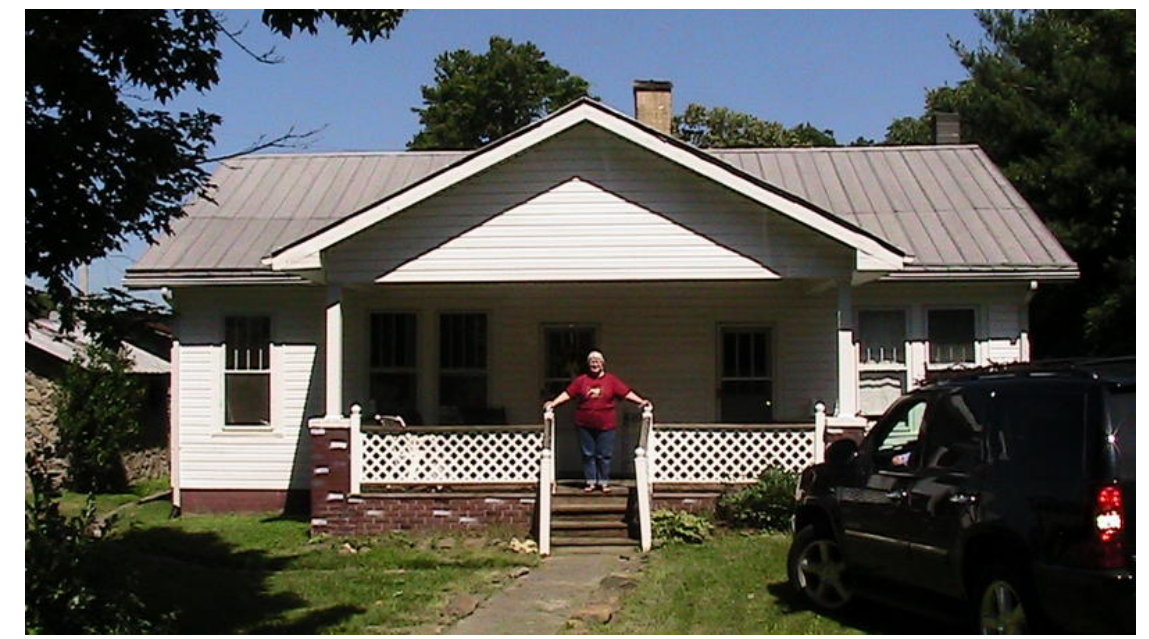

5.4 Sandy Horton on the porch of N.B. Kennedy and Tessie Colley's original house

This structure is more farmhouse than Victorian, and it was built in 1904.

A small dairy out back used to house a Delco Battery, making this the only house on Caney Ridge that had electricity at the time. Ginger uses the place now as a guesthouse, and she invites us to come and stay anytime. Standing at the little stone dairy building with my mom, I feel a chill run down my spine, like the proverbial walking over of one's own grave. Returning to Ginger's vehicle, I pause momentarily under an immense, shady oak in the front yard. This tree has been here since the earliest days of Mullins and Kennedy settlement of this mountain; if 
only it could speak of the different hands that climbed its limbs or sought shade from the sweltering, southern sun in the cool recesses of its shade. Standing in this spot that my family once owned and are now buying back acre by acre may be the closest that I get in my lifetime to the elusive spirit of Brandy Jack.

\section{N.B. Kennedy's Life on Caney Ridge}

N.B. Kennedy left Caney Ridge in the early 1920's, and then his dad D.F. moved into his house. Ginger tells us that the structure is virtually unchanged from the time that both men lived here. The land that Ginger owns, including this property, is a part of the original 200 acre homestead that N.B. had atop Caney Ridge. When he went bankrupt, N.B. sold it all to his dad. He did this as well to protect his assets from Tessie Colley when they were getting divorced.

There are rumors, both in print and passed along by word of mouth, that N.B. used his father's influence as a lawyer and a good deal of his assets to ensure that he received sole custody of his children. To hear my grandmother, Ruby Kiser, tell of it, Tessie named a price, and N.B. purchased each child from his first wife in that manner. It is no wonder that Grandmother Ruby doesn't speak much of her birth mother, that and the fact that she was barely old enough to remember her when the two divorced. 


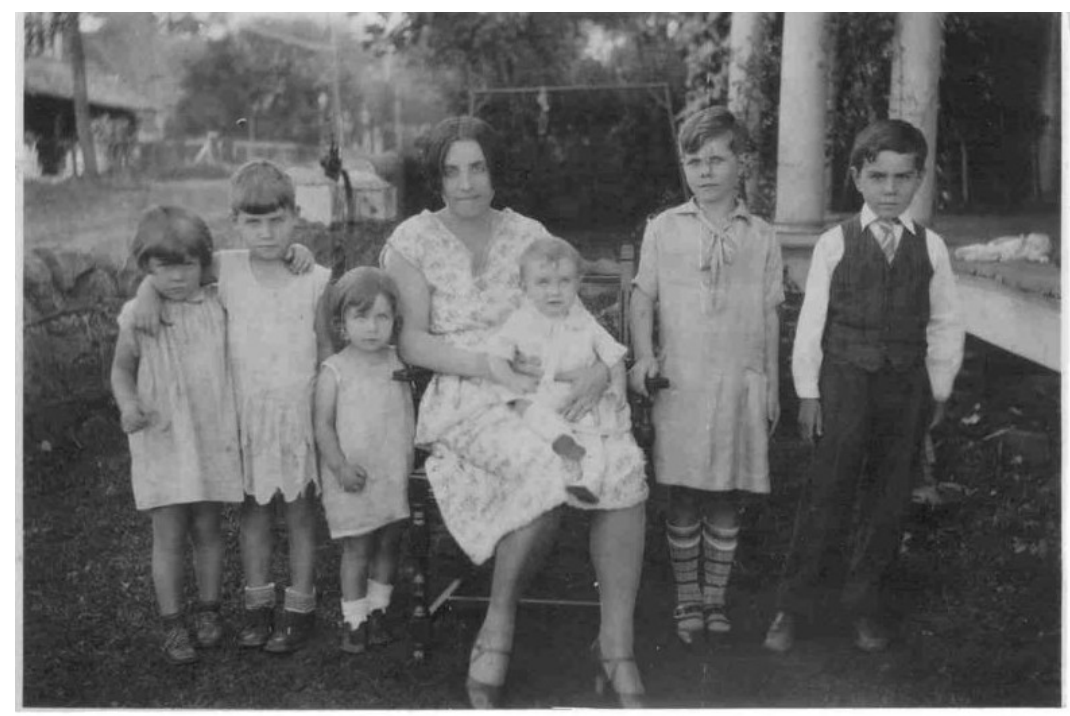

5.5 Tessie Colley with the Kennedy children on her last day with them

Much like my desire to know more about Kenneth Kennedy’s short life and tragic death, this mysterious story from childhood has haunted my mother for much of her life. She explains in an e-mail on her recollections of that day:

I had come for the story of Tessie Colley Kennedy, my birth grandmother who had died in1986... My mother had shared with me her only encounter with her birth mother when she was 20 years old. My mother's brother Kenneth had died in a mining accident. Tessie approached my mother at the funeral and touched my mother’s elbow. She said, "I am your mother." My mother turned and coldly replied, "You are mistaken. You are not my mother.” That was it. The relationship didn’t exist in her mind.

Tessie received $\$ 3000$ for each child and remained behind on Caney Ridge with the agreement that she would not contact them. I remembered the last picture my mother had taken with Tessie on the day she lost the children. My mother clung to her side as Tessie held her baby, Napoleon Brent in her arms. The sadness would shadow my mother's entire life.

As we drive away from Ginger's property towards one of the family cemeteries on Caney Ridge, I see several horses in a field and remember that NB used to raise racehorses. "Horses are in the blood," says Ginger. "We still have 
some of his original horses' babies on the farm. When N.B. went bankrupt, he still had money invested in either Ford or GM Motor Company, and he had money tied up in horses. At one point, he cut their tails and manes to make them look like common, work animals when the bank came around to assess his worth before the bankruptcy and divorce.” Despite the bad name that Tessie Colley has been given by the oral historians of our family, she stayed atop Caney Ridge and continued to live in the house for a time and raise horses on the land. Ironically, one of her horses went on to race in the Kentucky Derby, a feat that N.B. could never boast.

On our way to the family cemetery, we pass by Rachel's Chapel Road several times. Ginger tells me that it is a loop that circumnavigates the top of Caney Ridge. Rachel's Chapel is the name of the Freewill Baptist Church that Pleasant Kennedy founded with his three sons, naming it after his wife Rachel Jane Powers. When we reach the Kennedy cemetery, I ask Ginger why N.B. isn’t buried up here with his father and grandfather -- his eternal resting place is off the mountain between Wise and Coeburn next to his son Kenneth - and I remark to Ginger that my great grandfather never would talk about the death of his son, although it was a story that haunted my childhood.

She says one time N.B. broke his usual silence on this topic: "There was a picnic that Karen put together at the graveyard in Coeburn where her daddy is buried. Everybody knew it would be hard on N.B. to go there, and some said he wouldn’t even show up. But he surprised them all. He didn’t say much, but it was 
more than we ever got out of him. He said that day changed his life forever. When Kenneth died, a part of N.B. died with him.”

Ginger's parents are buried here too, which makes me realize that although from my perspective, the names on these stones are historical, they are also the parents, children, and life long loves of those who still reside on this mountaintop. Four of Ginger's siblings are buried here. Ginger was the first of five children to live through infancy. Like N.B., she holds her emotions close to her chest. Pointing at one of the small stones, she says: "This one here died from a prolapsed heart valve. Today they treat that with Tylenol.” Nodding her head, she keeps walking over these grey stones.

I am still so amazed with Ginger's knowledge of Caney Ridge; she holds the history of this place in her heart and mind. She knows every gravestone that I point to and the story behind it. That is one thing consistent about southerners; they love to tell a tale, pass on history in the oral tradition. Much like me, Ginger has been there to listen, to record the stories that surround her before they vanish in the air.

\section{Historical Mythology}

In writing a personal memoir on my extended family, I find myself straddling the wire between historical reality, facts that can be proven and documented, and family mythology, stories that have been retold but cannot be 
confirmed. Since I did not live through the events, and oftentimes, even the teller of these stories wasn't present or alive when they occurred, no one will ever truly know what happened, whether they are real or not. Still, people hear the stories told and retold; they are left to interpret these tales through their own perspective.

As we continue our drive around Caney Ridge, Ginger points out a wooded ravine called Dead Man's Hollow. The spot is named after a Civil War soldier who was wounded there. Several residents of the area found the man, bloody and unconscious, and carried him to a local cabin where his injuries eventually killed him. No one ever got so much as the man's name, so he is the unknown soldier of Caney Ridge. He is buried somewhere on that hillside just beyond the ravine.

At one point the Kennedys owned this whole hilltop, even the grave of this unknown man. Pleasant Kennedy and his brother squatted on this mountaintop for years. Eventually some lumber company tried to take it from them, but they ended up with a clear title. The Mullins Cemetery where Brandy Jack Mullins is buried is located on this bald hillside next to Old Lebanon Church. From these high open fields and clearings you can see clear to the other side of Wise, all the way over to the Hurricane, another high ridged hillside where people of Melungeon descent chose to make their home. 


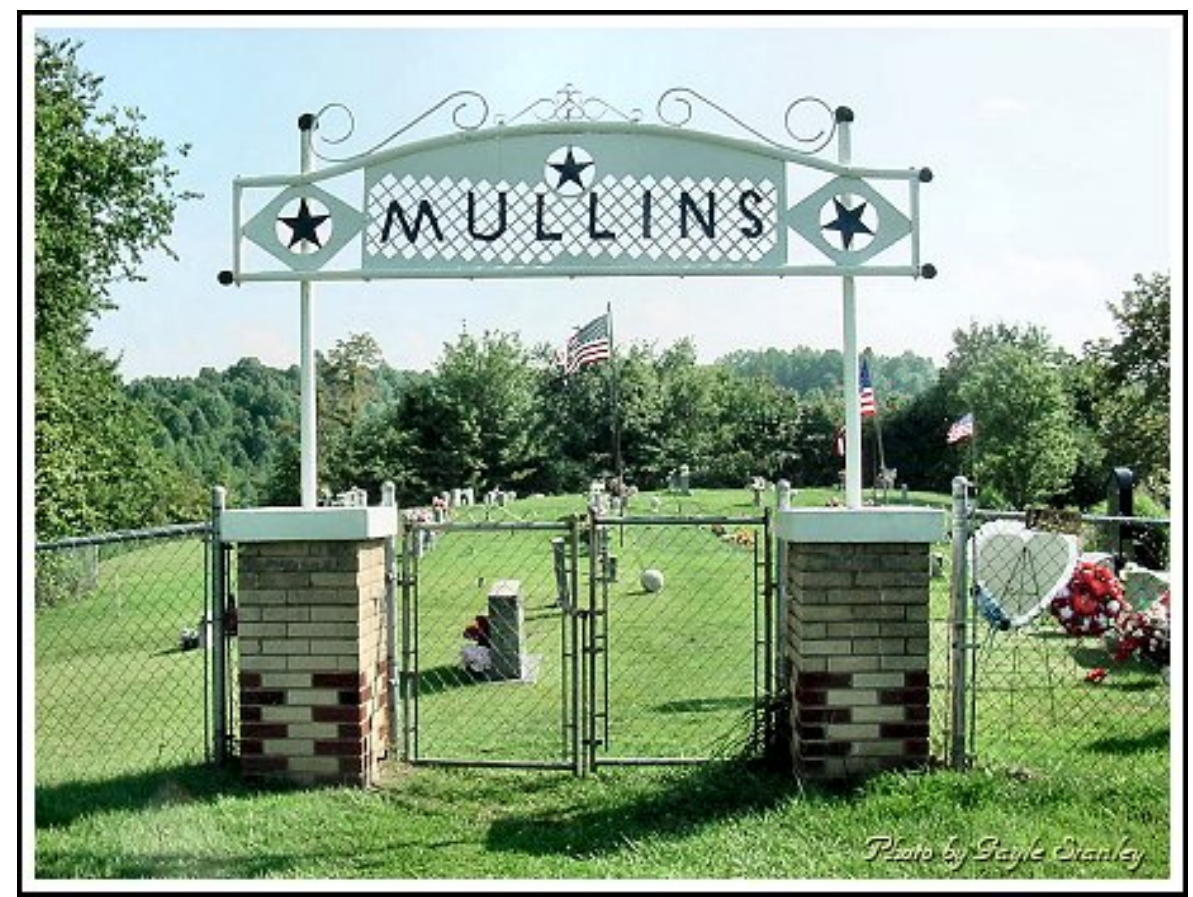

5.6 Mullins Family Graveyard at Lebanon Church with fine hand-wrought metal sign

We enter the cemetery through a hand-wrought metal gate. Bold black letters spell out the name Mullins, flanked by two eye-shaped ovals with stars where the pupils should be. The sign is a testament to the Mullins family's affinity for metalwork. The sign, which was crafted just after World War I, was made by one of the descendents of the master counterfeiter who was still plying the family trade at the time of its creation. The cold metal eyes with their star pupils stare out across the neighboring hills towards the Hurricane and further still towards Kingsport, Tennessee, another Mullins family stronghold.

While this is not the oldest cemetery on Caney Ridge, it is the most famous, as the final resting place of Andrew Jackson Mullins. We search the graveyard, 
combing through row upon row of Mullins stones, each one a tiny breath from the past, gasping for air on a granite sea of dates and names: Elbert Powers, Ida Mae Powers, Lucinda “Sin” Mullins Powers. Ginger raises the back of her hand to her lips and half-whispers, "They said she was as mean as homemade sin.”

Some names are fully faded. Others are bold and clear. I read the names aloud to Ginger who is searching on the next row, and she gives me a quick fact about the person. I come across an older stone adorned with a man’s picture that bears an uncanny resemblance to John Brown of West Virginia, abolitionist fame. When I give the name, W.J. Clay, Ginger responds, “Old W.J. married my grandma, not the first time, but the second time around.” Without a break in stride, we continue our search. Where is Brandy Jack?

Ginger isn’t sure, but he very well may have been the first one buried here. Is it possible that he simply vanished, up and moved, headed back out in search of that lost Swift Silver Mine that some say he found and others claim never existed at all? It is certainly humbling coming up empty handed while searching for a dead man on a hill. Some stones look new in stark contrast to the old; others have names that have been painted over older stones, giving them an awkward, surreal appearance. Amongst these, I find the original stone, small and bleached bright white by the sun and elements with the simple letters, AJM. I cannot help but think that this stone is too tiny for the sizable, storied life behind it. 


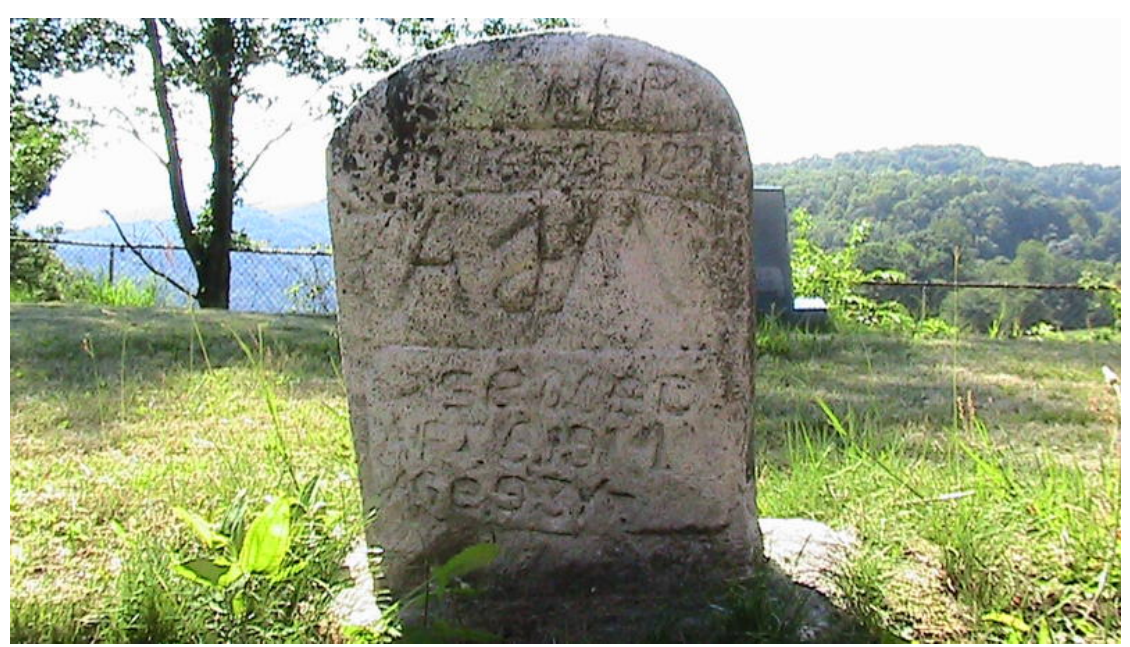

5.7 Original Brandy Jack gravestone with valley view in background

As if she could read my mind, Ginger locates Brandy Jack’s grave on a different row. This stone is much larger and obviously newer. There are two different stones for the same man, yet another testament to his larger than life persona: Brandy Jack Mullins - too big for one grave. Even the dates on this second gravestone add to the man's mystique. They read February 22, 1813-April 9, 1917, making him more than a century large in legend. His actual birth date is 1824, but this newly etched, cold granite lies quite well.

As I gaze out across these ancient mountains, fading dark bluish, purple hues against the late afternoon sun. The view from here is stunning. Like some fabled center of the universe. I shift my gaze to Ginger on her walk back to the car. I think of her as some sort of ancient prophet, resurrecting the lives and stories of her foremothers and fathers simply by walking across their graves. 


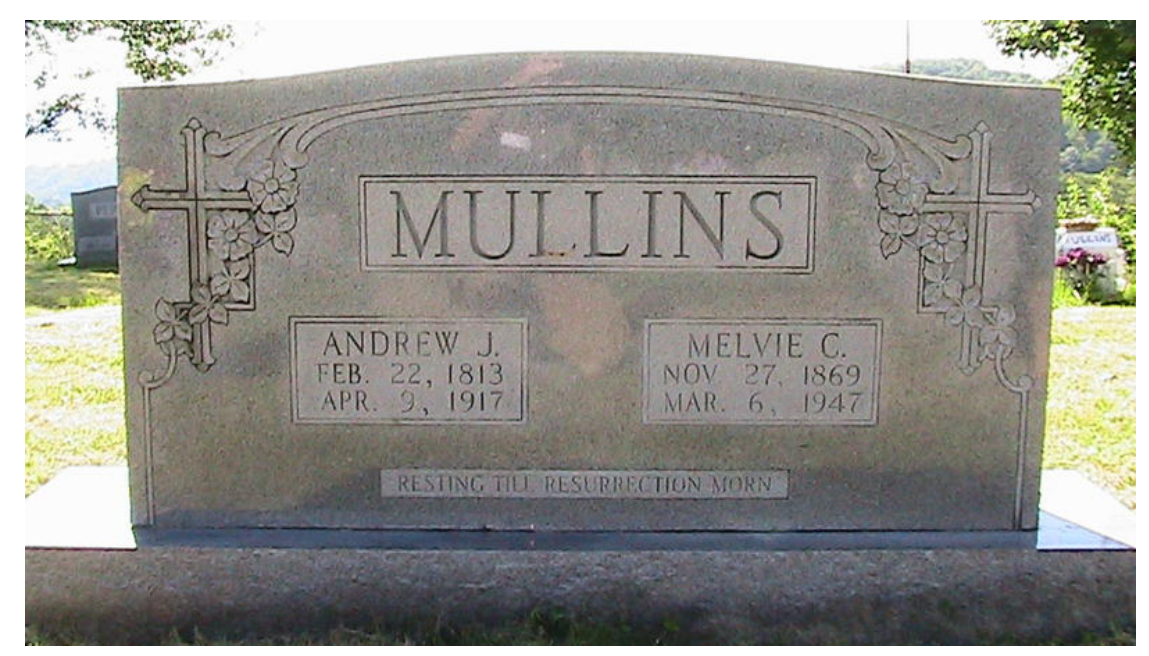

5.8 Newer Brandy Jack stone with wrong date, making him 103 at his death

We completed the loop around Rachel's Chapel Road back to Ginger's house to meet up with Karen and refuel with cookies and sweet tea. While our time on Caney Ridge has in some ways left my mother and me with more questions than when we arrived, it has also reconnected us with a side of the family that, until now, was just a list of anonymous names on a lifeless tree. Our visit to Ginger's home has ensured the fact that the stories will stay alive for at least another generation or two.

My mother and I depart Ginger and Karen’s company with a flurry of hugs and promises to stay in touch, and we make our way down the windy mountain road, through Pound, then Wise, and on to the Hurricane. Unlike Caney Ridge, my mother has spent a considerable amount of time in this area, from her days in Wise as a child up until Mamaw Kiser's funeral in 1972. One of my earliest recollections in life, a half-memory muddled by countless retellings, occurred here. I recall sitting on my mother's lap in our green MG convertible at the outskirts of a 
somber gathering. All faces in the crowd were strangely sad and formal in contrast to the normal feelings of warmth I associated with my mountain kinfolk. We sat in silence as my father played reluctant pall-bearer, toiling his way up the muddy hillside, carrying Mamaw.

How strange it is to be here once again at my mother's side nearly forty years later. The air is warm, and the ground is dry. We are the only people around. So many of the original attendees of Mamaw Kiser's funeral are now dead and buried alongside her. As we pay our respects, I realize that there is so much I don't even know about my own mother, her life as a child in Wise, her hopes and dreams, the person she was and wanted to become before I was born. I know that one day I will visit this place without her; sadder still, one day I will perform this same ritual at her graveside, keep her story alive for my children's children to hear. We are family; this is what we were put on this earth to do for one another.

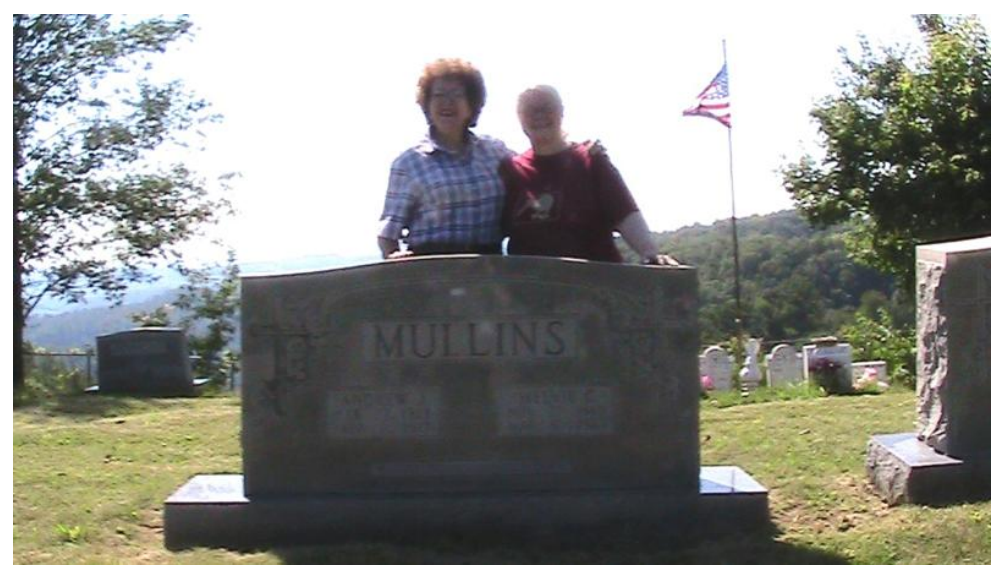

5.9 Ginger Senter and Sandy Horton at one of Brandy Jack’s gravestones 


\section{VI}

\section{Mahala Mullins}

"Brandy Jack" was not the only member of the Mullins clan to gain notoriety. Being Melungeon, members of the Mullins family had no place in mainstream society. To the southwest of Caney Ridge, just over the Tennessee state line, lies Newman’s Ridge, another Melungeon community populated by a different branch of the Mullins/ Collins family tree. This remote mountain community is more publicized than its Virginia counterpart, as it was home to Mahala “Big Haley” Mullins, the Queen of Moonshine.

Mahala Mullins was as big a woman as her story is large. She was born Mahala Collins in 1824, the first child of Solomon D. Collins and wife Gincie Gwinn (Goins) Collins. At a young age, she married Johnnie ‘Skinney’ Mullins, becoming Mahala Collins Mullins, but she was commonly referred to as "Big Haley” by those who knew her. Her husband John was the son of "Irish Jim” or “Hare-lipped Jim” Mullins.

Mahala lived her whole life in a cabin in the steep hills of Newman’s Ridge. She remains one of the most famous Melungeons not only for her high quality bootleg whiskey, but also for her immense size. She was infected by wucheria bancrofti, a parasite that led to her contracting Elephantitis in the later years of her

life. Although she was a large framed woman by nature, weighing in at almost 300 pounds before the Elephantitis ravaged her body, she likely reached a weight of over 500 pounds during her lifetime, though common lore puts her upwards of 800 . 


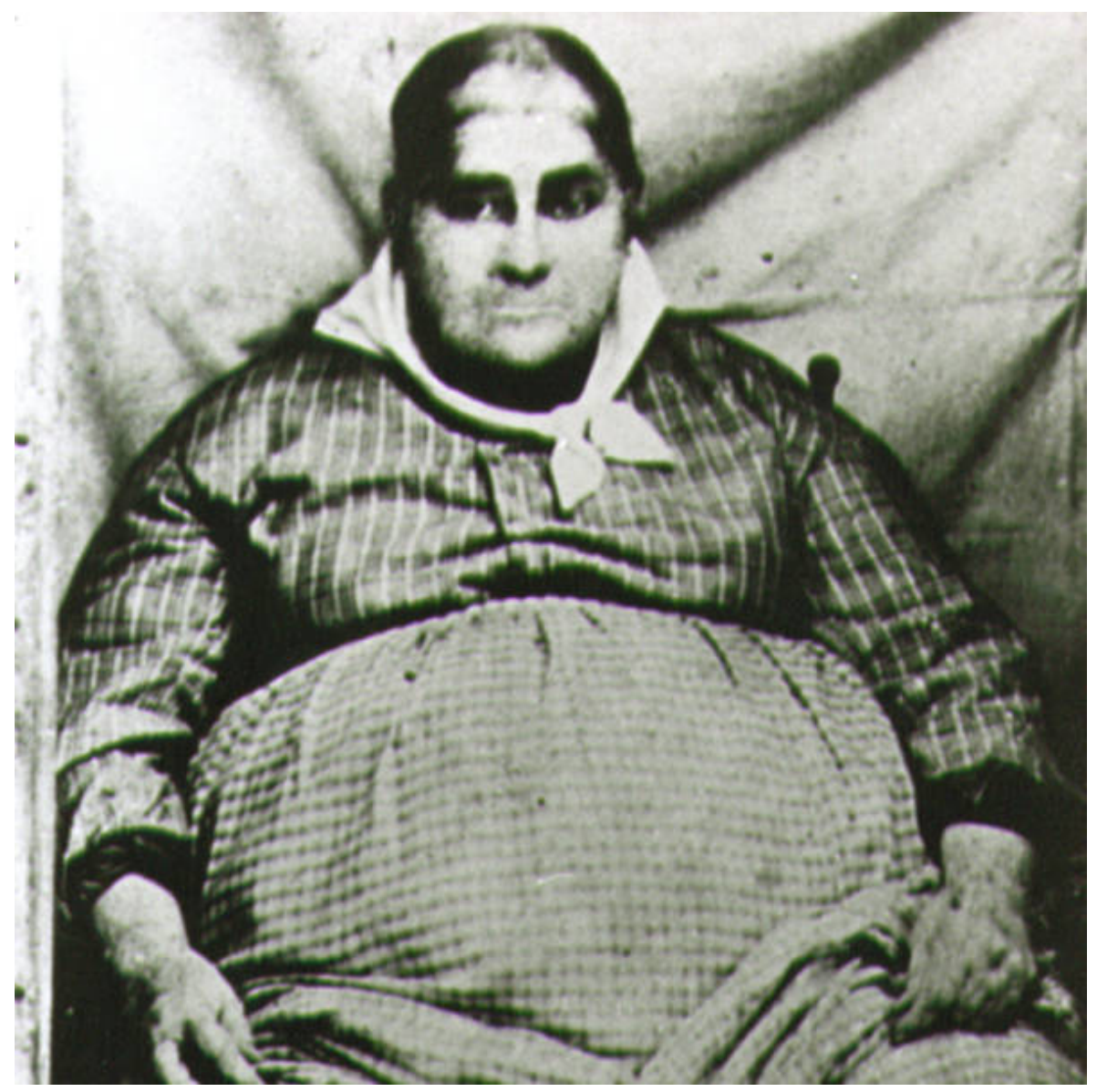

6.1 Mahala Mullins, suffering from Elaphantitis, weighed over 500 pounds

\section{History}

In her childhood, Mahala’s family thrived in the area surrounding the small town of Sneedville, Tennessee, but this prosperous way of life was short lived. As more light skinned pioneers began settling in the area, life became harder for Melungeons as they had no legal rights to the land that they had lived on and worked for generations. Tennessee law changed in 1834 making it harder for Free 
People of Color, a category in which the Melungeons were often placed, to get an education, vote, or own land. Melungeon families were pushed off of their land and into the hills and hollers on the outskirts of town to the less bountiful Newman's Ridge area. The animosity towards townsfolk and frustration at their lack of options led to violent reactions from Melungeons in many cases, especially during the Civil War when they raided and looted the very same land and houses that used to belong to them. These instances did little to legitimize the Melungeon name, creating a mixture of fear and hatred for these darker neighbors.

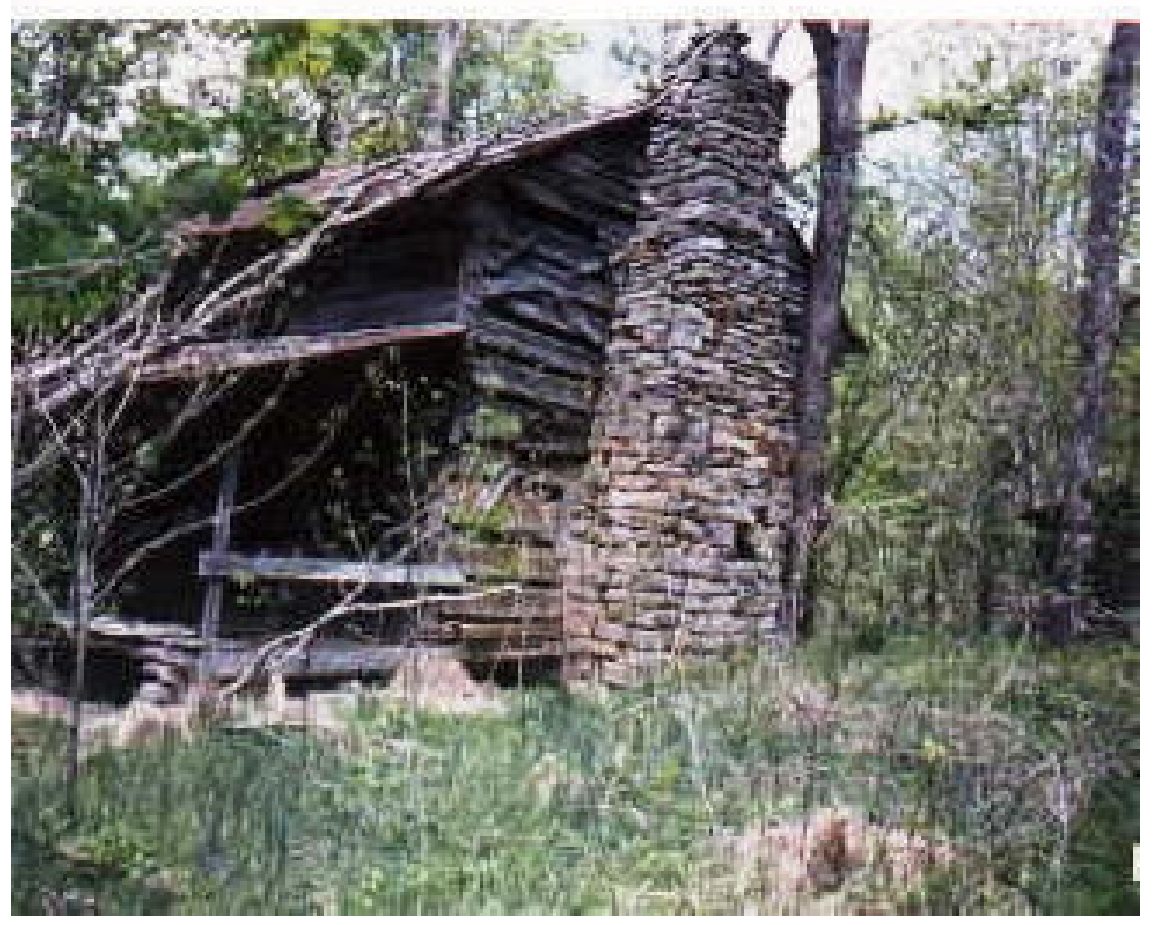

6.2 The Mahala Mullins Cabin fell into disrepair in its original location on Newman's Ridge

Despite being pushed into the hills, Mahala and her family managed not only to survive, but also to thrive in their relative isolation on the outskirts of town. No one knows how many children Mahala Mullins actually had over the course of 61 
her lifetime, but it was likely somewhere around 20, with 15 living past infancy. She gave birth to these children over a nineteen-year period. The first one, was born in 1841 when Mahala was just seventeen years old. Her youngest son Calvin was born in 1860, and Mahala also adopted a boy named Burton, born in 1846, in the later years of her life.

\section{Illicit Activity and Violence}

But it wasn't motherhood that made Mahala Mullins famous. Mahala is one of the most well known Melungeons because she produced high quality moonshine. Making alcohol had always been a more lucrative use of grain than selling the crops to be milled. Although she lived some half a century before the Volstead Act of the 1920's that launched the era of prohibition, Mahala's trade was still deemed illegal by lawmakers and lawmen alike.

Individual states passed laws on the manufacture and distillation of grain into alcohol, and by the 1850's many states moved to total prohibition of the practice, deeming private manufacture of alcohol illegal. Distilling moonshine brought fines of ten to several hundred dollars or incarceration in prison. Mahala's home on Newman's Ridge was isolated enough that she was able to ply her trade for quite some time with minimal interference from the law. When the law did intervene, the most they ever did to Mahala was destroy her equipment and fine her for the trouble of having to travel up the ridge.

Alcohol, apart from being illegal, also caused other problems for the inhabitants of Newman's Ridge, Mahala's family in particular. Several of 
Mahala's children ran afoul of the law and a few lost their lives plying their trade as illegal moonshine bootleggers. Her sons were heavy drinkers, and their bouts with moonshine often made them violent toward others as well as themselves. Richard died when his gun misfired in a brawl. The attacker slit his throat and threw him in a well. Another brother, Ollie, was shot to death in downtown Sneedville during a shootout with Sheriff Grant Jarvis.

Other instances of violence that involved Mahala's family were related to their choice of sides during the Civil War. While Tennessee was the $13^{\text {th }}$ state to join the south in seceding from the Union, a great number of residents, particularly inhabitants of the Eastern portion of the state, joined the North in an attempt to save the Union. It makes sense that Melungeons -- being of darker color, having lost rights, and commonly referred to as Free People of Color -- would side with the North in an attempt to abolish slavery and hopefully restore some of the rights that they lost along the way.

Larkin, Jim, and son-in-law Howard Collins were home on leave from the Union army when Confederate raiders came looking for them at the Mullins property. Mahala's house was no stranger to Confederate raids. Soldiers knew which side her sons were on, and her illicit liquor trade meant that she had cash and other bartered goods to loot. Alerted by his wife Jane Mullins, Howard and the two Mullins boys took a few shots at the approaching Confederates before escaping down a ravine. According to different accounts, Howard broke a finger or maybe a 
leg during the escape. Although the three Union soldiers escaped with their lives, the raiders looted and burned the house to the ground.

Shootouts with the local lawman and run-ins with Confederate raiders were not the worst things that could happen; sometimes the violence turned on itself in the form of a family feud. In 1895, Mahala's youngest son Calvin got into a fight with his cousin Willie, accusing the crippled man of having slept with his wife, Coose. Both men were known for their run-ins with the law. Calvin had multiple revenue and firearms violations, and Willie was a known pyromaniac. He lit a neighbor's mule on fire in an effort to delouse it, and he set a man's bed ablaze while he was in it. Calvin chased Willie with a shotgun, and eventually hit him so hard in the head with the butt of the rifle that he knocked Willie's eye out of its socket. The half-blinded Willie then drew a .38 caliber pistol from his waist and shot Calvin dead.

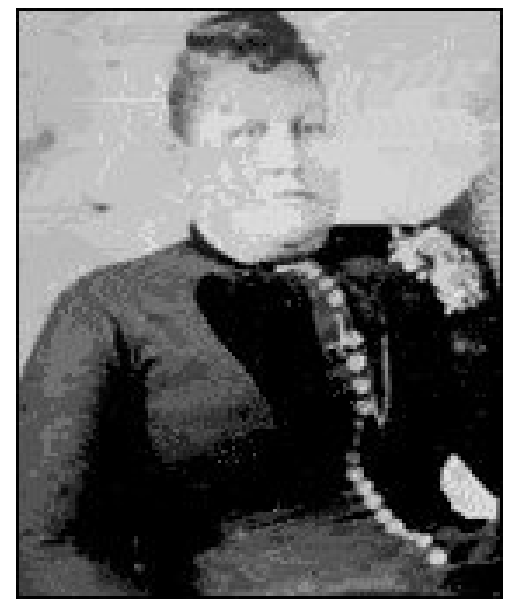

6.3 Mahala Mullins in earlier years 


\section{Myths and Tall Tales}

As with Brandy Jack Mullins, stories surround Big Haley Mullins, most of them related to her rough and rowdy ways, illegal bootlegging, and brushes with the law. Even myth surrounds the most tragic events of her relatively long life. Supposedly, after witnessing her youngest son Calvin’s senseless, brutal murder, Mahala said, "I can’t let this good shine go to waste, I’ll just drink it myself." When the family home was burned by Confederate raiders, it is said that her husband, John Mullins, in his anger, overloaded the muzzle of his gun and left the ramrod in when he took a shot at the fleeing raiders. The rod supposedly shot clear across the valley and stuck into a post near the Hurley household west of Vardy Church. Whether these incidents actually occurred or are just hearsay, the stories elevated the Mullins clan to the level of myth.

While most of these stories are simply folk tales or "fakelore," they are worth mentioning for the insight they provide into popular culture's fascination with the self proclaimed "Queen of the Moonshiners." According to one obvious tall tale, Mahala at seventeen, entered and won a wrestling competition for men at a politician's picnic. After beating all the contestants, some two and three at a time, she then proceeded to sell them all liquor in tiny gourds provided by her seven husbands. When the judge declared her a bigamist, she retorted that she was looking for a couple more good men to marry. In other stories, large groups of men scale the high ridge to Mahala’s home in order to arrest her for illegal bootlegging. It was even said that her house sat directly on a county line, so when the sheriff 
came to arrest her, she could simply move to the other side of the house to evade capture. This myth persists, despite the fact that maps and census records prove Mahala lived some four miles from the Virginia border for her entire life.

Another famous story about Mahala Mullins and the law involves a young deputy trying to make a name for himself by apprehending the woman once and for all. When he got to her house, he found Mahala inside -- but because she was so fat, he couldn't get her out through the narrow doorway. Upon returning to town, the disappointed lawman was forced to admit to the judge that, "she’s ketchable, but not fetchable.” Legend has it that when this physically and metaphorically large woman died in 1902, her more than thirty husbands and a dozen or so cousins laid her out on the bed and built a makeshift coffin around it to fit her. Since she was too big to pass through any doorway, they tore down the chimney, the only part of the original house that had withstood the Confederate raiders of years past, in order to take Mahala to her final resting place. She was buried on the family land alongside her sons Calvin, Richard, Ollie, and all of the other children who died in infancy over the long, hard years.

\section{The Queen of Moonshine}

Mahala Mullins remains the most famous Melungeon in history. Even late into the twentieth century, men would boast that they had purchased 'shine from her, despite the fact that they were scarcely born before she died. Although she saw the turning of the century, the "Queen of Moonshine" was long buried by the time mass prohibition hit the United States in 1920. 
There are also many fictional accounts of Mahala. Author Jesse Stuart portrays her as Sylvania in his novel Daughter of the Legend. The novel takes place in the fictional setting of Sanctuary Mountain which is modeled after Newman’s Ridge. The narrator informs us, “There never was a better woman than Sylvania. When she sold you a gallon of moonshine, you got a gallon of unadulterated moonshine and not two quarts of moonshine with a quart of water and a quart of carbide all stirred up well and shook before drinking.”

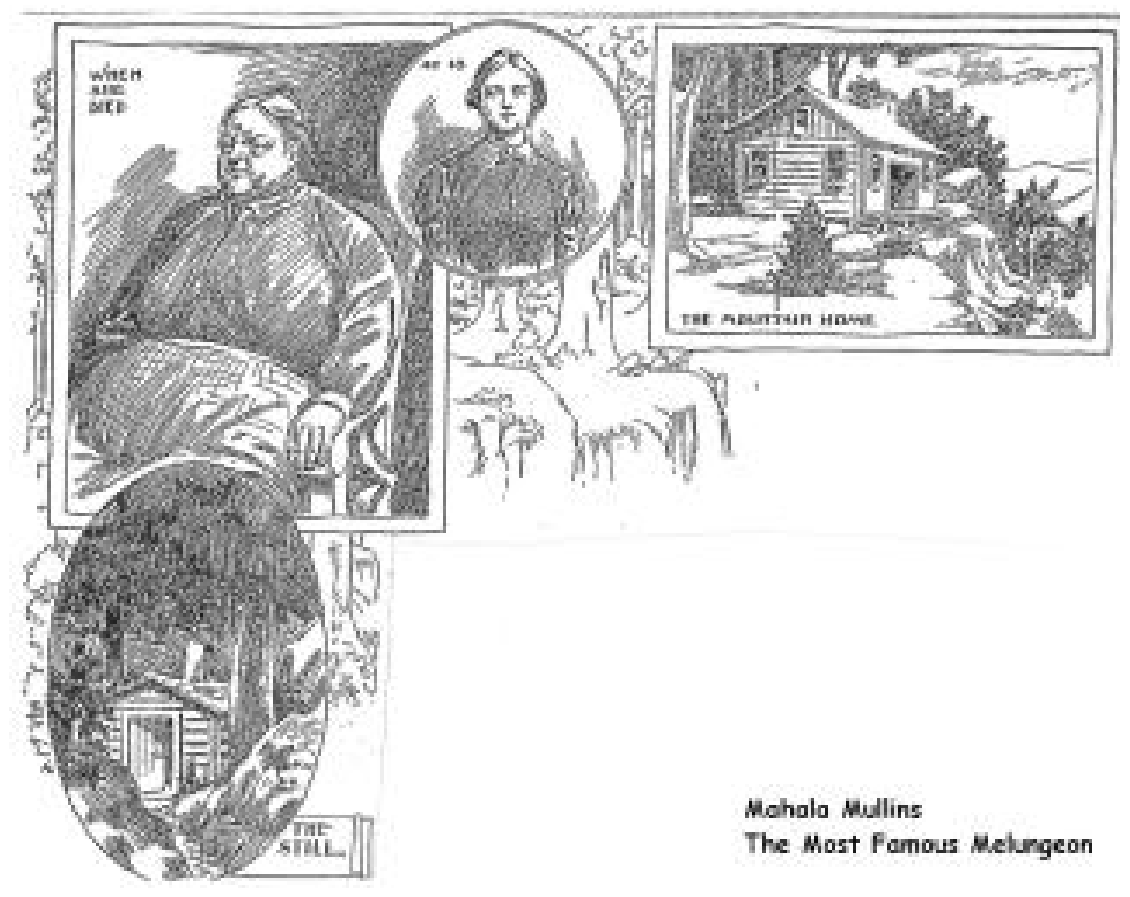

6.4 A magazine dramatization of Mahala's life as a Moonshiner 
In 1937, James Aswell wrote an article in the Nashville Banner entitled

“The Lost Tribes of Tennessee’s Mountains.” Although the piece was published in the news, it reads like pure myth, even giving the article's main character the name Betsy, though she was obviously based on Mahala Mullins. An excerpt from his article describes the woman:

At the Beginning of her career, Betsy is said to have tipped the scales to a neat 600 pounds. Some versions of the story state, in addition, that she towered seven and a half feet into the thin mountain air and that she could 'heft' a yearling bull over her head with ease. When she sat down to a light meal, she commonly downed a whole pig, hide, hoofs, and all. She could tear a firm-rooted pine from the earth with one hand and could splinter a two inch oaken plank with her bare fist. Around her arm, she could bend a forged iron crowbar as an ordinary woman might wrap a length of silk ribbon. In a word, Betsy Mullins would have been a fitting match for the Heracles of American lumber camps, Paul Bunyan.

His misquoting of Mahala's name leads the reader to believe that he was more of an erroneous fact gatherer than a creative essayist. Mahala did have a sister in law named Betsy, which could have lead to Aswell's confusion of the name. But once a story gains momentum, as soon as a misconception reaches enough people through the sheer telling of it, then even an outright lie holds some sense of truth. 


\section{VII \\ Following the Trail of Mahala Mullins}

I've just spent two weeks in the mountains of North Carolina researching, writing, and visiting family. While fly-fishing a remote stream near my Blue Ridge Mountain home, I was bitten by an unidentified snake. There was no swelling or allergic reaction, just two tiny red marks evenly spaced on my right calf as a reminder of what could have been. Now, some twelve hours later, I am winding the backroads of Southwest Virginia into Tennessee, my father at my side.

As we approach the outskirts of Sneedville, Tennessee, I sense the growing anticipation in my stomach. Maybe it is the realization that our journey has begun, or it could be the thought that I will soon be standing on Mahala Mullins' front porch for the first time after reading so much about her life. Or maybe it is simply trace amounts of snake venom coursing through my veins.

\section{Touring Sneedville}

When we first enter Sneedville, I am a bit surprised by its size. In reading historical accounts of the town, I thought it like Knoxville or at least as big as Kingsport. But the city center consists of just two blocks: a courthouse, a jail, a few run down shops: nothing more. With a population just over 1,300, Sneedville is scarcely larger than the small towns surrounding my cabin in North Carolina; it

had less than half that population at the turn of the $19^{\text {th }}$ Century. It is mid-afternoon on a Wednesday, and we find the town abuzz with pre-holiday excitement. While 
people are walking on the sidewalks with cars passing to and fro against a backdrop of red, white, and blue banners that line the street, no one appears to have any fixed destination.

Nowhere is July $4^{\text {th }}$ more evident than in these economically depressed mountain towns. These small communities put even the biggest city's display of patriotism to shame with their belief and dedication to a system that has all but passed them by. It is as if they could only believe hard enough in the American Dream, it would swoop down and carry them off to a brighter tomorrow. Fireworks stands boast the newest in explosive devices, the courthouse is draped in patriotic banners, and the few small shops that line the main street advertise holiday sales and savings on every window.

The town is nestled in a flat bowl between two prominent ridges, and I know that one of these two hillsides has to be Newman's Ridge. Driving through the small main street of town, my question is answered for me as I pass Newman's Ridge Rd to my right. It is the larger of the two ridges, looming over the whole town, stretching as far as the eye can see. It was here, on this high rocky ground, that people of Melungeon descent were forced to live and eke out whatever existence they could manage.

Much like Caney Ridge near Pound, Va. and the Hurricane near Wise, Newman's Ridge is a mountainous region on the outskirts of town, more remote and less desirable for settlement. Newman's Ridge feels closer to Sneedville than 
its Virginia counterparts are to Wise or Pound, but the trip down to town on horse or foot still would have taken a good while back in Mahala Mullin's day.

Before heading up the ridge, I go to look for the historical society, located in a small annex in the alleyway behind the old jailhouse. We find the building easily enough. It is located on Jail Street in the heart of the town center. The original jail site is preserved as a landmark, and the historical society housed within actively preserves the rich heritage of the surrounding area. Unfortunately, at the moment, it is also closed, although it is still early afternoon on a weekday.

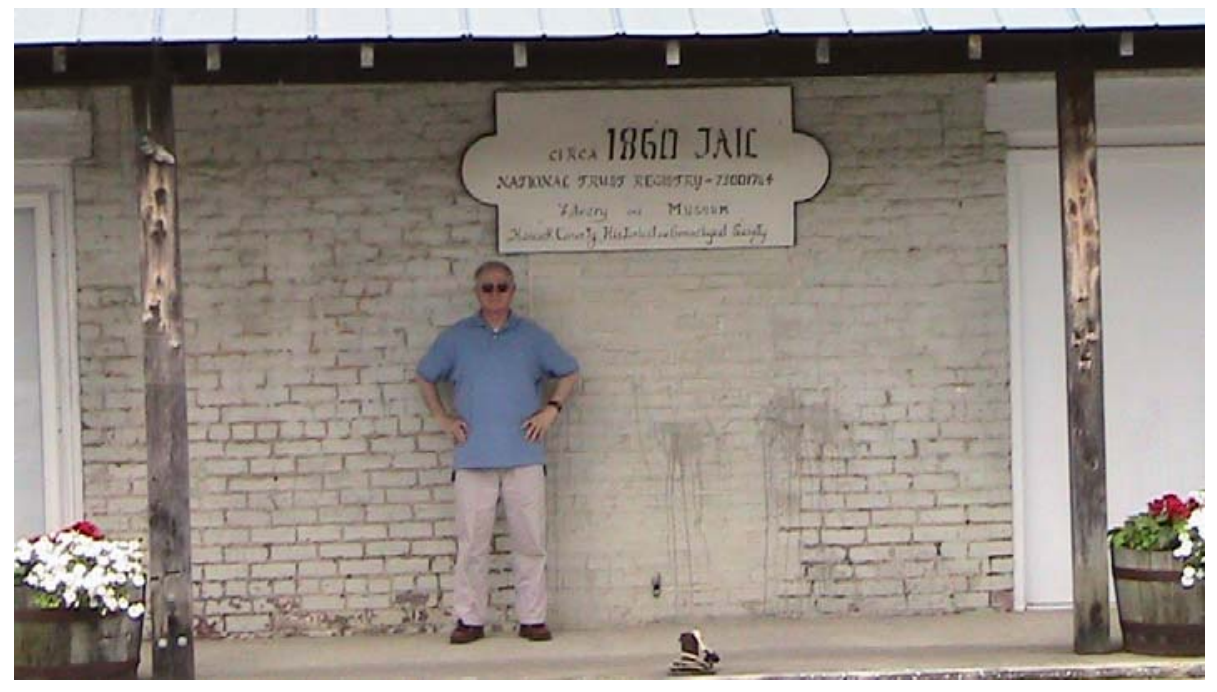

7.1 Ron Horton Sr. in front of the old Sneedville Jail

It seems like the entire town is already on vacation. Stopping at the courthouse in the hopes that someone there can answer my many questions or at least share some local stories about what life might have been like here during Mahala Mullin's time, I find the large, wooden double doors of justice are already locked to the public. 
A bearded man on the courthouse steps watches me try the doors in vain. He looks like a hung over mechanic or railway hobo with his grease stained hands, tattered work clothes, and sparse toothed grin. I assume he is waiting for a trial or debating whether to surrender himself to authorities after they finish their mid-day meal. As I turn towards the car, he nods at the front doors and comments, "Reckon your business 'ul have to wait a while. Best not to rush the long arm of the law.” I nod back in agreement and walk on missing what, in retrospect, would be my only opportunity for conversation the whole day. As I walk off leaving the nameless man to his legal fate, I can't help but wonder, is he a Melungeon? Are we related by blood or marriage?

As we drive aimlessly around Sneedville, I begin to feel more and more like a stranger. I sense the local inhabitants’ inherent mistrust of outsiders. Ironically enough, this communal aloofness is also mixed with a reluctant acknowledgement that visitors are a necessary evil in order for this depressed economy to survive. Unlike most areas in the southeast where Melungeons settled or were forced to relocate, Sneedville by all appearances accepts its Melungeon heritage and the importance of documenting the area’s history. When it comes to Melungeons, Sneedville is unique among other similar cities. With its active historical society, Vardy Museum, and the preservation of the Mullin's homestead, it is much more tolerant and accepting of its dark-skinned neighbors in the surrounding ridges and hollers. 
Part of the reason for Sneedville's ability to co-exist more peacefully with its Melungeon populace is that the group has a more organized community here. The town of Vardy, just a few miles over the ridgeline from the city's center, is a Melungeon stronghold that began as a family settlement in the late $18^{\text {th }}$ and early $19^{\text {th }}$ Centuries. Nestled between Newman's Ridge and Powell Mountain, Vardy began as a tiny mountain hamlet that provided an alternate town center for the educational, spiritual, and commercial needs of local mountain dwellers.

\section{Traveling to Vardy}

We turn onto Newman's Ridge Rd. and wind up the steep hill just north of town. We crest the ridge, and the road begins winding down into a valley below. My father shifts his gaze from one side to the other, and then glancing backwards notes, "looks like you can see both ways. These switchbacks show you where you're going and where you've been just the same. Kinda like it's uphill both ways.” As the road angles downward, I become a bit less certain of my ability to sense direction than I was just moments earlier, but it levels out into the valley flats, and I see a small green sign on the roadside that clearly states in white letters, Vardy/ Mahala Mullins Cabin. 


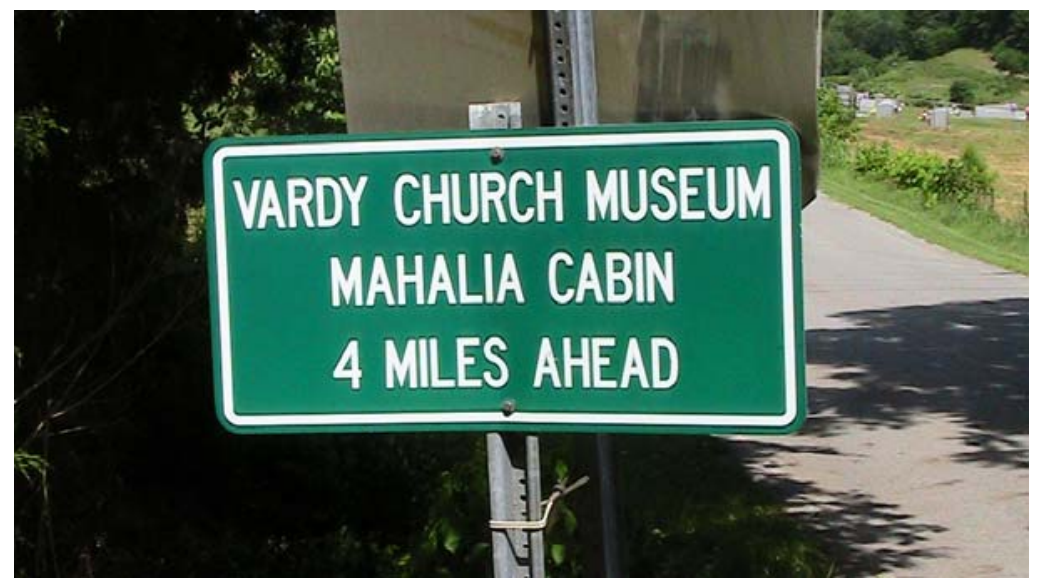

7.2 Sign to Vardy and Mahalia (spelling variation) Cabin

Following the signs, we turn onto Blackwater Rd. I begin videotaping the journey. We drive past small homes, farms, trailers and dilapidated barns. The road is relatively straight, with occasional slight rises as it traces Newman's Ridge to our right. Passing by an open barn that serves as a makeshift garage, my father spies an antique Cadillac, peppered with rust. "Look at that one, boy," he nearly shouts as he points out the window. I can't help but smile at his love of aging cars, a curse he unknowingly handed down to me. Passing another leaning barn, I reply half to my father and half to the air, "Some of the people around here are probably distant relatives of ours. These trailers and houses and barns and small family plots are indirectly linked to us, even if only by name.”

The road is narrow but relatively straight, and we can see an old man walking about a half mile in front of us -- a distant cousin of ours? Although the majority of people who settled this area were from the Mullins and Collins family, there are a dozen or so other families who made their home here and still reside in this valley and the surrounding ridges. I remember through my research that there 
were also some inhabitants of Vardy with the last name Horton. While the Horton name in my family comes from my father's side, and it is not a commonly recognized Melungeon surname, I wonder if there is a relation to these Hortons as well. With enough research, will my family trace itself back full circle, both sides linking somewhere in these ancient hills?

The valley is so lush, and it looks as if there is a creek running along the edge of it just before the ground slopes upward. We pass the Sulphur Springs Missionary Baptist Church, one of the early places of worship in the valley. As we drive along towards Vardy, my dad takes the video camera and films, so I begin narrating. "I wish we could just go up to one of these houses and knock on the door, but I don’t wanna get shot.” He nods and shifts the lens to the skyline along Newman's ridge.

“I’m sure some of these folks aren’t so happy about this whole historic preservation idea,” I continue. “They probably don’t want to feel like some animal in a zoo, with people coming by gawking and staring, snapping pictures. It's pretty ironic that in Mahala’s time, Melungeons were looked on as outcasts from normal society, cast into the hills to fend for themselves. Now folks like me go searching for them, and all they probably want is to be left alone.”

We reach the Vardy community, which was originally comprised of the Vardy Church and Vardy School. Back in the mid-1800's, much of the community operated on a barter system among the valley residents and ridge dwellers. There 
was a small store and an Inn at a local farmhouse for passersby, but Vardy itself operated for the most part independently of the neighboring Sneedville.

This area, already rich with Melungeon history, is now also the site of Mahala Mullins cabin. While the cabin was originally perched high atop Newman's Ridge, it has since been moved to Vardy in an attempt to preserve its heritage for future generations. The cabin now serves as a living history museum, a structural testament to the local "Queen of Moonshiners" Unlike Caney Ridge, where the story of Brandy Jack remains more of an underground mystery for family members and insiders only, Mahala's story is out in the open, on show for everyone.

\section{Visiting the Mahala Mullins Cabin}

Over the years, Mahala's cabin changed owners multiple times, eventually ending up vacant and falling into disrepair. In 2000, the Vardy Historical Society moved it from Newman's Ridge to its present spot across from Vardy Church. Looking at the hills behind it, I try to imagine what this cabin must have been like in its original location, nestled high on the hillside far away from the prying eyes of lawmen and laymen alike. Mahala would not have approved of the cabin's current location, out in the open for all to see. 


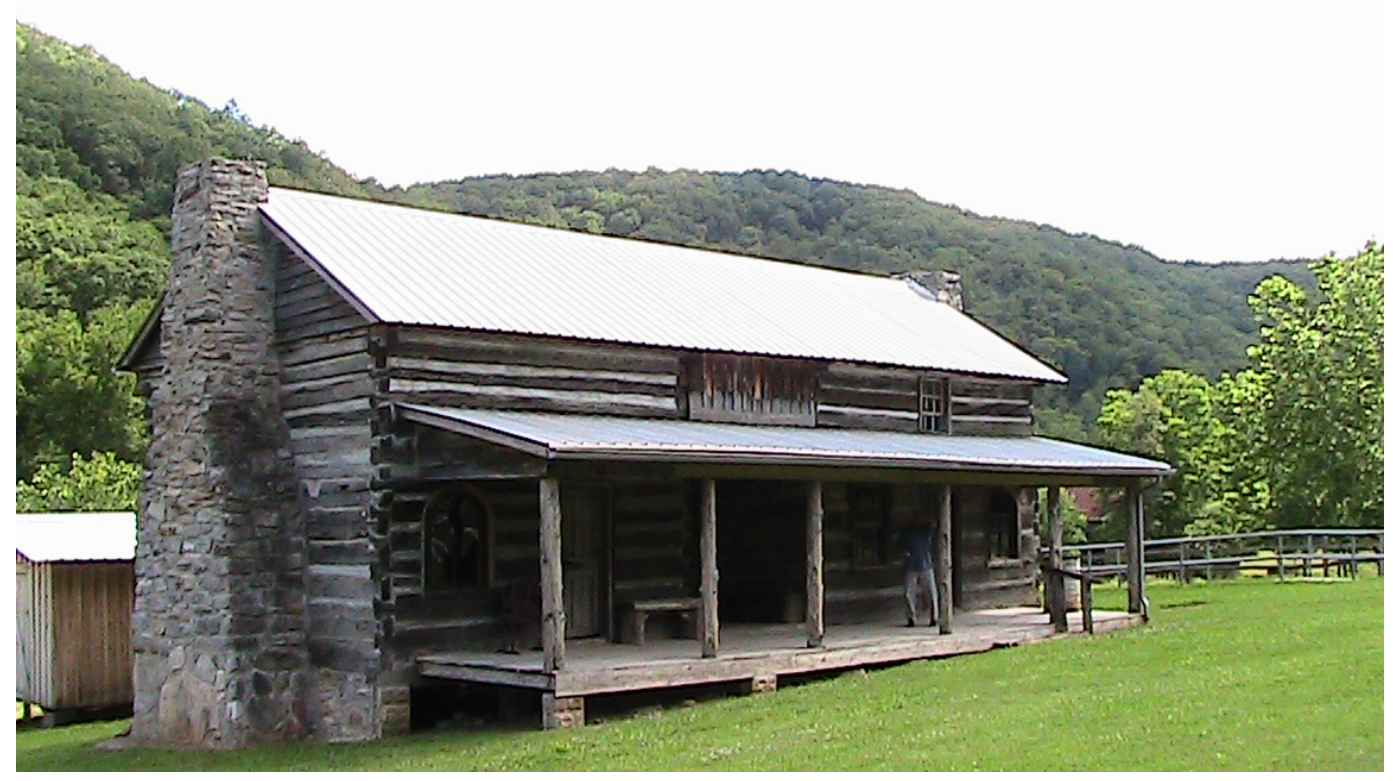

7.3 New Vardy location of Mahala Mullins Cabin with Newman’s Ridge in background

We pull up to the cabin where it sits, quite sturdy and intact, just off the main road on a vast, lush green lawn against the backdrop of Newman’s Ridge. Much like the Vance Cabin on Caney Ridge, this structure looks its age, fits the history that goes along with it. If the two were put side by side, this one must be at least four times as big, the Cadillac of cabins. It has a covered front porch with five hand cut timbers supporting a tin roof overhead. A corridor cuts through the center of the porch to the back with doors flanking on the left and right into two separate ground level rooms. Each side of this lower section is a single, open room with a hearth on the side wall. One was Mahala's bedroom, while the other served as a dining/ living room. There is a loft on the second floor that stretches the expanse of that level with one window to the upper right. Both sides of the cabin boast massive stone chimneys, each one an intricate example of handiwork towering several feet above the top level. 


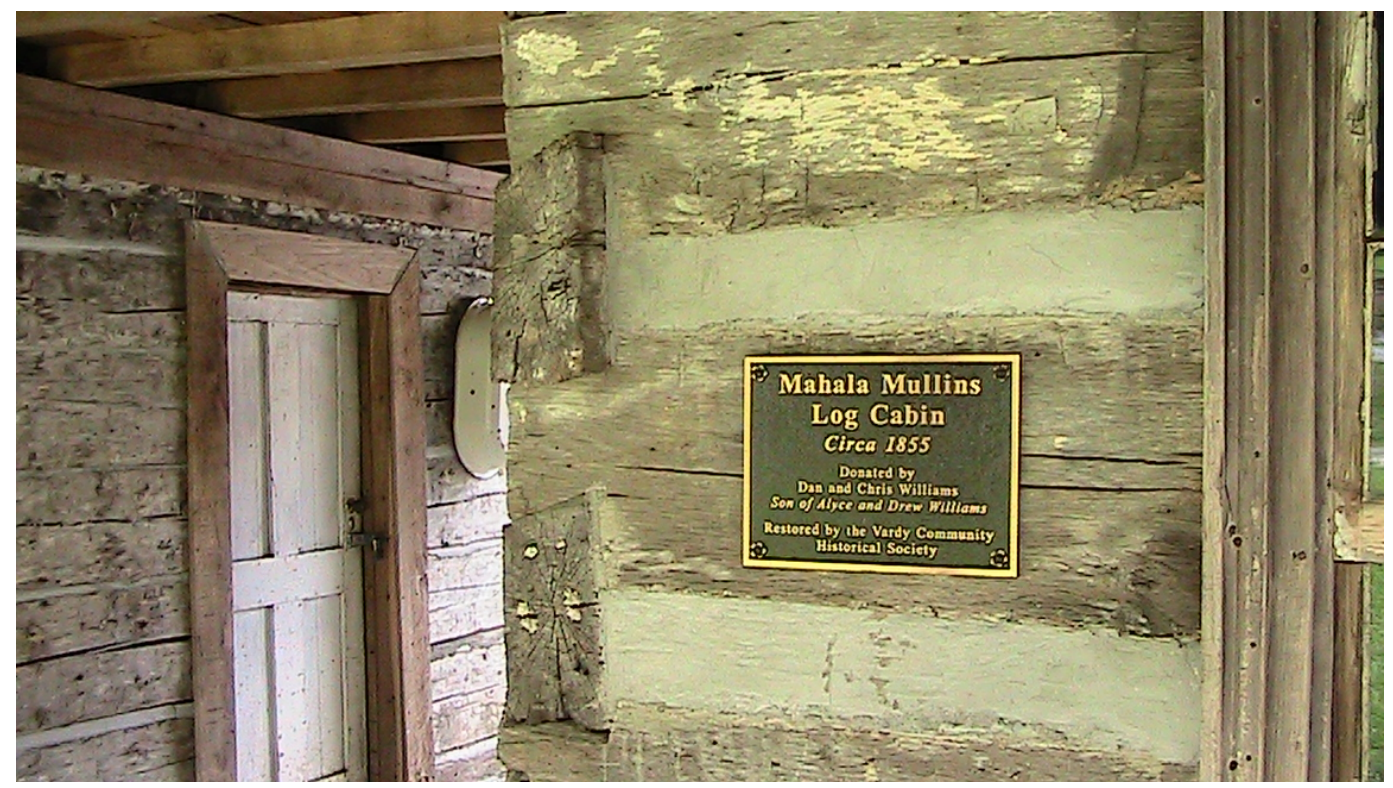

7.4 View from front porch with plaque and inner hallway door

Unlike most simple cabins of these rural southeastern hills, Mahala Mullin’s cabin has ornate woodwork around the doors and windows. The lower front windows have high arches, like some backwoods cathedral. While each lower room can't be more than 150 square feet, and the top level no more than 400 square feet more, the overall structure has a very sturdy, roomy appearance in contrast to most cabins of its era. It boasts an awkward mix of function and fashion. Think of the work it must have taken to move this whole structure, log by log and stone by stone, from its perch high atop Newman's Ridge. The fabled story of tearing down one of the chimneys to retrieve Mahala's corpse comes to life as I look at these immense, stone smokestacks. 


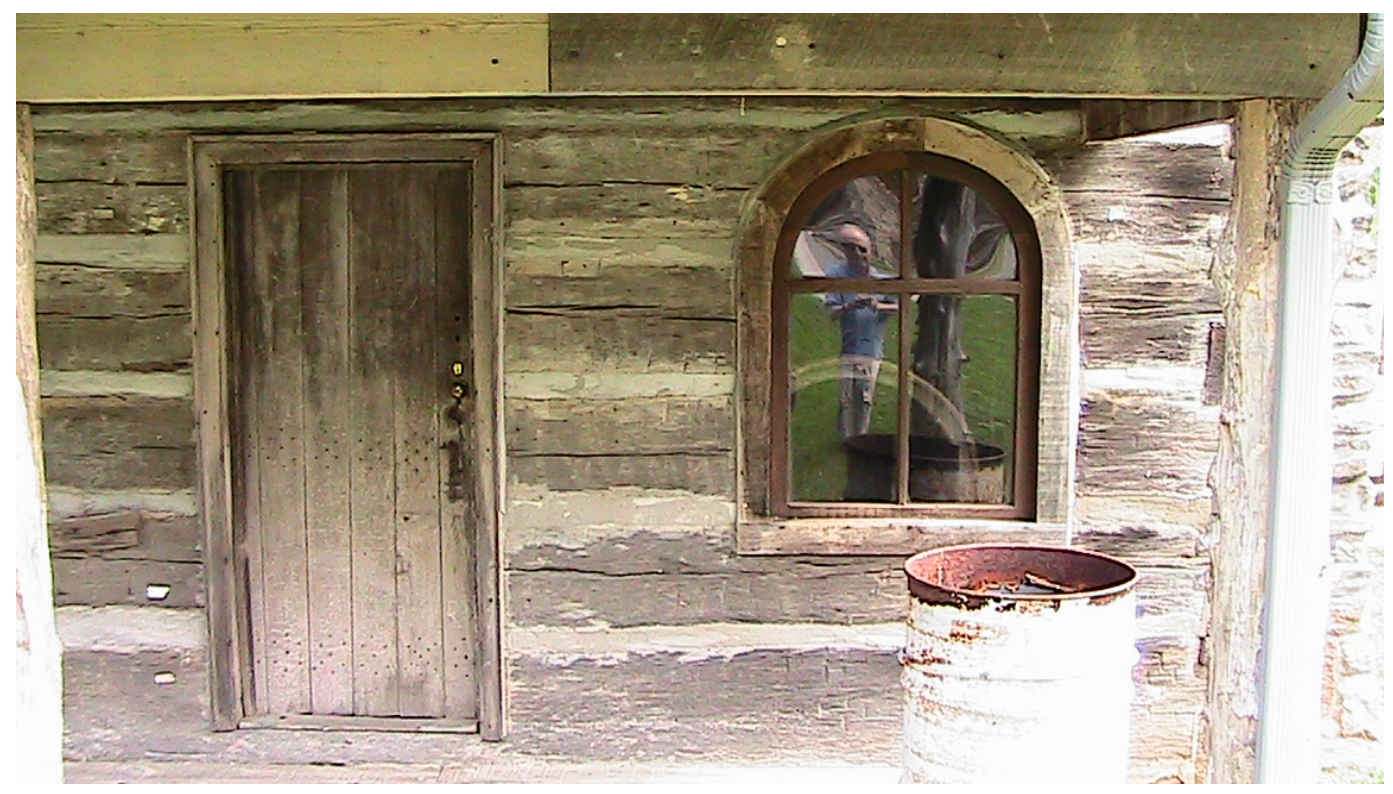

7.5 View of cabin door, woodwork, and ornate windows

Like the historical society and the courthouse in Sneedville, this cabin exhibit is closed. Peering through the ornate windows, the inside of each room has been decorated with period furniture and artifacts. Filming through the window, I catch my reflection in the rippled glass as the camera's lens peers inside of the house. There is a hearth to the left with an oil lamp, various utilitarian knickknacks, and a picture over the mantle I can't quite identify. On the back wall is a small staircase up to the loft. To the right of it is a picture on the wall of a woman, presumably Mahala. A bed sits kitty cornered against the closest wall to the window. The room is simple, but it holds a certain warmth even in its sterile emptiness. This must have been Mahala's bedroom. She had to have been too large to navigate the narrow loft stairs. 


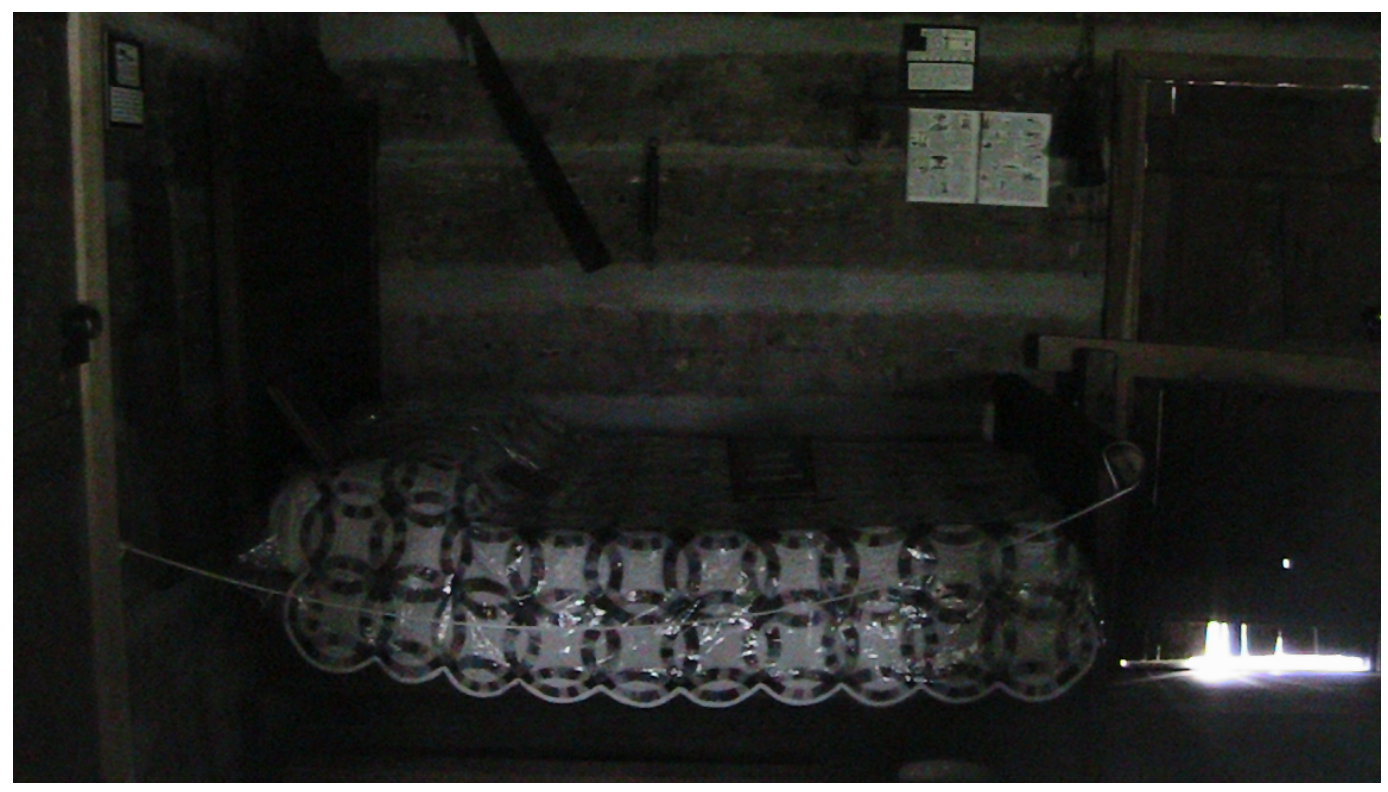

7.6 Interior of Mahala Mullins Cabin furnished with period furniture

As we continue to explore the outside of the cabin, there is still not another soul in sight. The place has been preserved tastefully, not too flashy but ready for visitors. I can't help but feel glad that I came on a day when no one else was here. The newly renovated cabin comes complete with public restrooms and a wheelchair accessible concrete walkway. There is a covered kiosk with information about the original inhabitants who settled this area: heavy plexi-glass covers a poster sized excerpt from my cousin Brent Kennedy’s Melungeon book. But there is no one around to give these places life, to explain their true importance to the people who lived and died here.

Although I would love to have gone inside and gotten a feel for the place, I think I would have liked it even better when it was a hollow shell falling apart high on Newman's Ridge. I am torn between understanding the need to preserve history 
and detesting the amusement park feeling one gets from standing behind ropes and looking into the past.

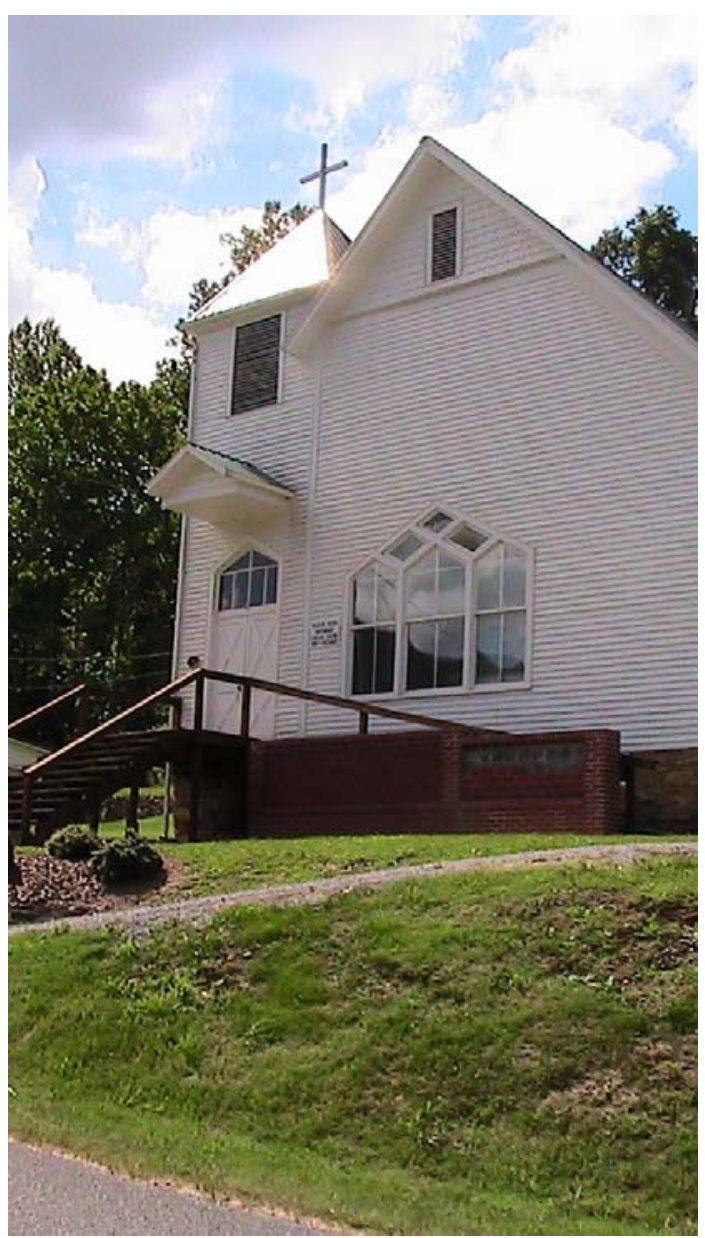

7.7 Vardy Church: the center of the Vardy Community then and now

\section{Searching for the Path to Newman's Ridge}

We continue to drive up Blackwater Road in search of something that I already sense is unattainable. Passing the Vardy Community graveyard, my father and I debate stopping to search for graves of relatives. Although Mahala Mullin’s unmarked grave on Newman's Ridge has been lost to time, there are most likely 
other names from our family tree scattered in the different plots along the roadside. Deciding not to stop, we drive a bit further experiencing our first local interaction of the day in the form of some good old country dogs. Fixing a gaze on my Labrador in the backseat, they relentlessly pursue the car and herd it to a near standstill. I wonder what would happen if we accidentally hit one of them, picture myself walking up to a strange door, limp lifeless body in my arms, trying to explain.

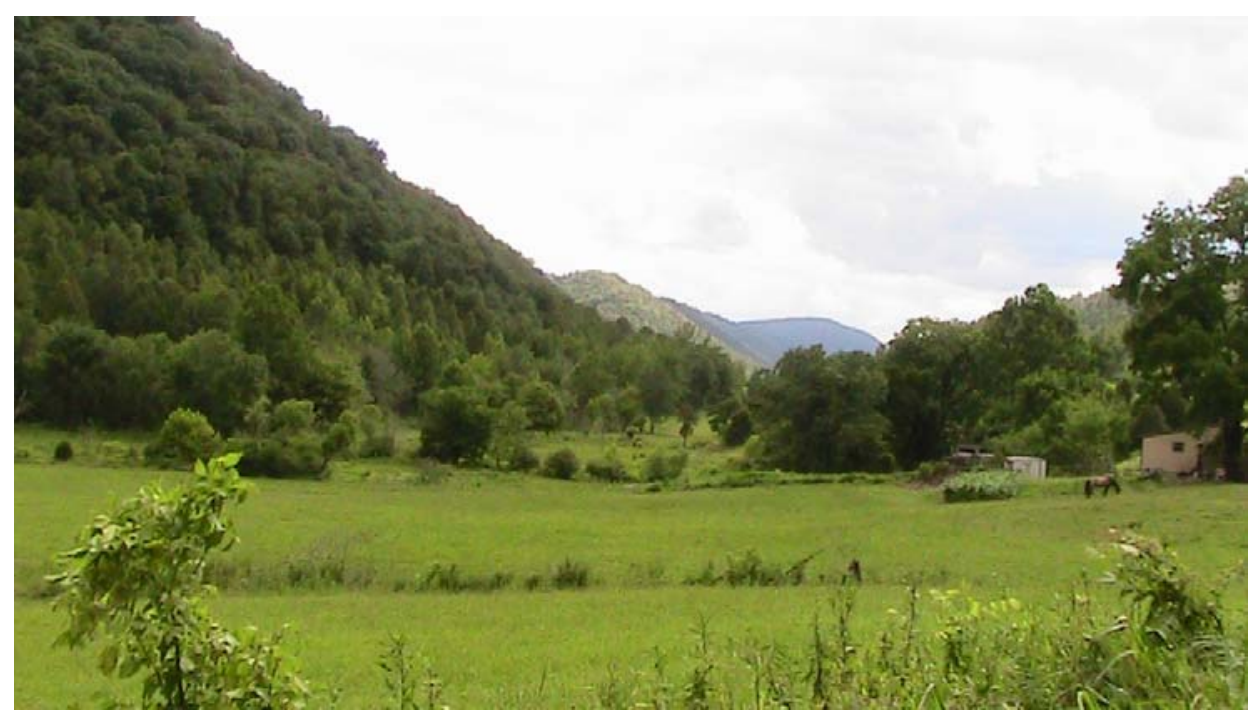

7.8 Blackwater Valley: Home to Vardy Community and the relocated Mahala Mullins Cabin

We continue up the road, past the dogs, into the great unknown, passing an even mix of doublewides, falling barns, modern homes, and ancient log cabins.

Scanning the words on mailboxes, I come up with only a handful of names, mostly Mullins and Collins. In the not so distant past before museums and guided tours, one would have needed either an invitation or a badge and posse to get this far into the inner sanctum of Vardy and the Blackwater community. As the road narrows 
and begins winding up the hillside, I can sense my father's desire for me to turn around and go back to town, but for some reason I just can't do it. I want to push it just a bit further, see what's around the next bend, as though if I kept driving I could somehow reach the past, see this place the way it once was before roads and rest areas and historical restoration. Newman's Ridge is on my right, and beneath it the fertile farmland floats past the open window, dotted with stands of trees. I can faintly make out a small creek or stream winding just on the edge of the forest where valley meets hillside.

As an undergraduate I minored in archaeology and spent a great deal of time doing field work on land just like this. It was thrilling to envision what a place looked like in the time before. So much of any historian's work lies in the realm of the imagination. How did it feel for the Collins and Mullins when they first set foot on these rugged climes of Newman's Ridge and into the lush, Blackwater Valley below?

I feel as if this road will somehow lead to Newman's Ridge if I only keep going, but it turns gravel, then dirt, and I remember that I have Oregon plates, making me a tourist in my own part of the country. I drive a bit further, somehow feeling defeated by my utter lack of destination. My father points out, “This right here is the type of road that, if you aren't visiting someone, you don't really have any business being there.” Even in this world of GPS, cell phones, and 911, a person could get lost back here never to be seen again. In the modern world, with the legalization of alcohol, marijuana and methamphetamine have become the 
modern form of bootlegging, and the people who ply this trade are equally as suspicious of strangers stumbling onto their turf. While I see no evidence of illegal activity in the surrounding area, my good sense sometimes gets the better of me, and I realize that a U-turn is the best idea for the day.

Driving back down, the roads grow wider and more improved. As we leave Blackwater Valley and Newman’s Ridge behind, my father recalls, “There was a story I came across where one of our relatives in Virginia, maybe on your granddaddy Kiser’s side, bought a huge tract of land for $\$ 700$ in gold that he had minted himself.” And with that remembrance, the oral tradition continues from father to son.

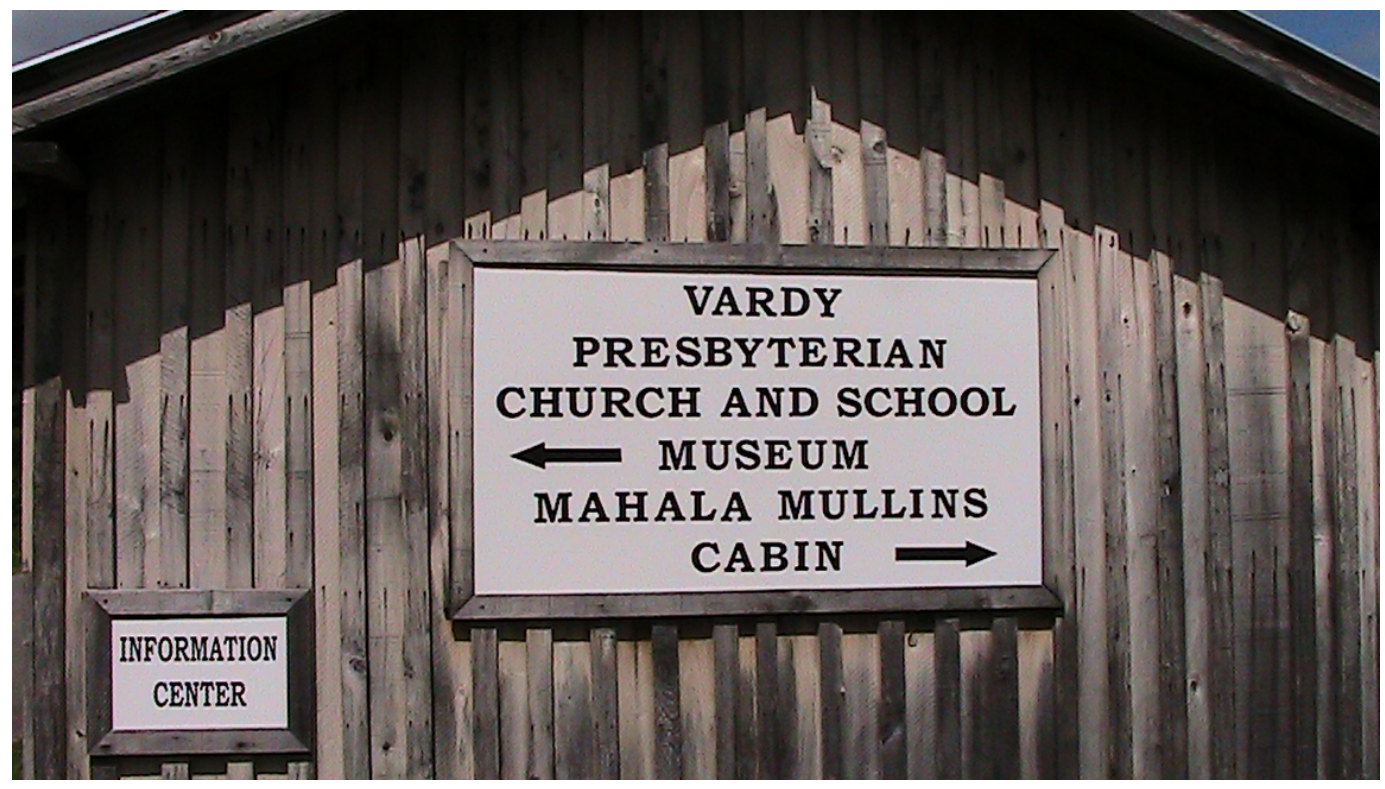

7.9 Example of easy accessibility of historic Melungeon locations and information 


\section{VIII \\ History As Myth}

“Once I think a thing, it becomes real, even if it can’t be true.”

-D.W. Caudill

"Coal Black Heart”

Before pen and paper, storytellers originally plied their trade around campfires and kitchen tables. While the oral tradition is not the best means of recording facts, it does allow for a certain liberality in the recording of history, as each new teller of a story is allowed to put his own unique bent on the events he is relaying. The fish gets bigger each time it is caught, the path is uphill both ways, the women grow more beautiful and cruel. Other times, the facts surrounding a person or event are scant, bare boned. With only the faintest hint of detail to cling to, we are left to create a story, and images from other stories enter to fill in the gaps.

\section{The Concept of Mythmaking}

One story that was never mentioned in our family was the death of N.B.'s son Kenneth. Kenneth was the oldest boy in the family, and with that role came all of the benefits and pressures of the first born son: all of the hopes and dreams a father has to pass along to future generations. As best as I could gather from the few stories I heard over the years, he always stood up to the test. He played football at the Columbia Military Academy in Tennessee, and he went to Milligan College for two years. In 1943, he went to war, serving in the U.S. Army Air Corps as a Navigator and Flight Engineer. He returned home in 1945 and married 
Colleen Hughes. They named their newborn baby Karen. He went into business for himself, leasing a coal mine in between Norton and Coeburn, Virginia. Then, on May 22, 1947, less than three weeks after my father was born, Kenneth died before ever seeing his twenty-sixth birthday.

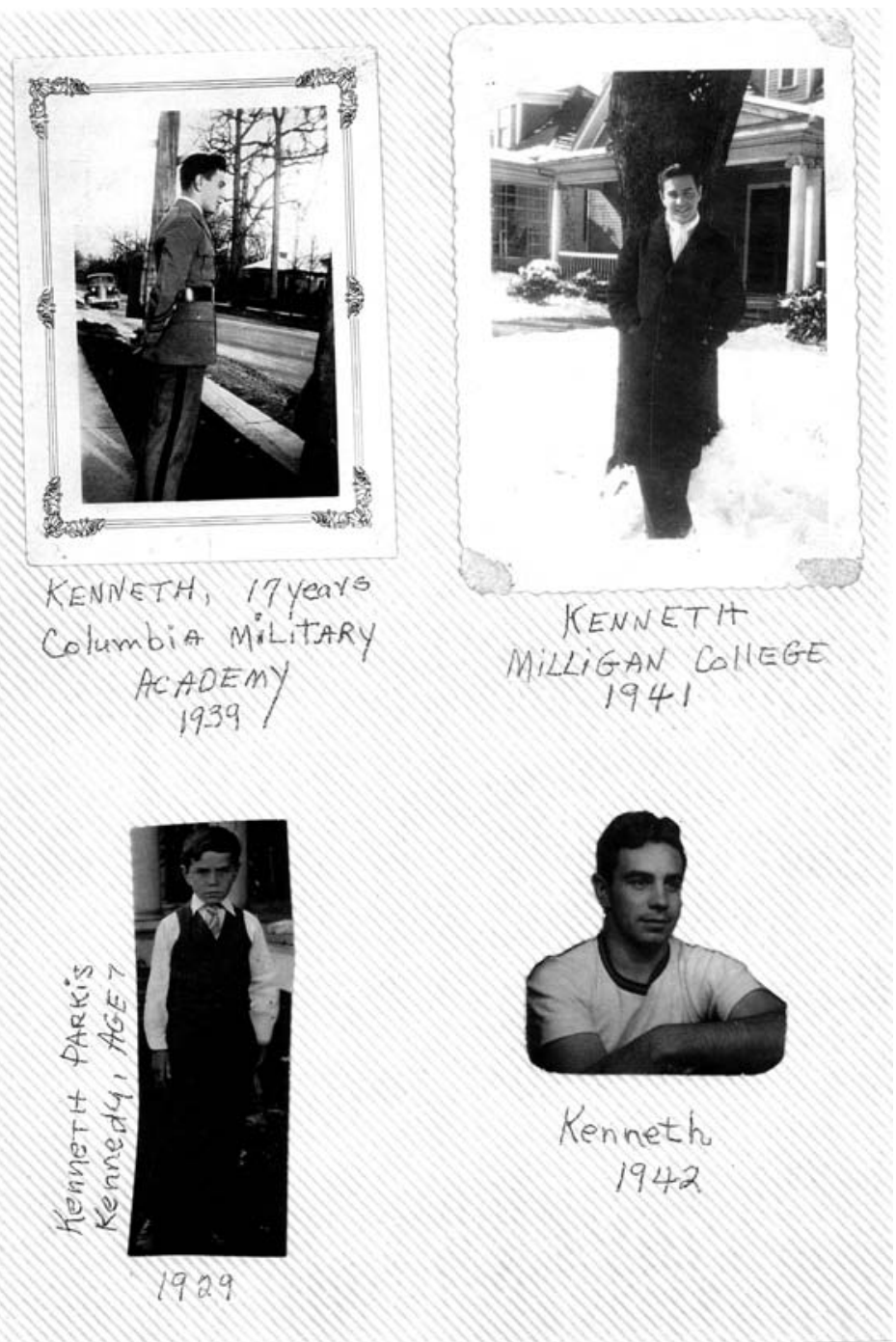

8.1 Photo array of Kenneth from age 7-20. He died at age 25 
Most of the details that I have about the coal mining accident that killed

Kenneth come from an obituary in the local newspaper, The Coalfield Progress, on

Sunday May 25, 1947:

Indications of a heroic but futile attempt to save his friend's life appeared in the mine between Norton and Coeburn where the bodies of Kenneth P. Kennedy, 25, and James Cox, 20, were found early last Friday morning. The body of Kennedy was nearest the mine entrance. Appearances near the body of Cox and beyond indicated that Kennedy had attempted to help him to the mine entrance and safety before succumbing himself to what was believed to have been carbon monoxide poisoning... Young Kennedy entered the mine at approximately 10:00 o'clock Thursday night when he did not find Cox at the entrance where they usually met. Early Friday morning young Kennedy's father, Mr. N.B. Kennedy... went into the mine where they found both men dead, Kennedy only 20 feet away from the entry.

I can remember sitting at my great grandfather’s kitchen table doing everything I could to not bring up this story that I yearned to know more about.

The entire six hour trip from my home in Richmond to his house in Wise, Virginia I was warned hourly not to bring it up. I imaged N.B. approaching the mouth of that mine on a brisk, Spring morning searching for his son, his first tentative steps into the cold, dark tunnel, and his weighted return carrying the limp body of his dead first born. This image has haunted me ever since I can recall. 


\section{Conversations With Karen Kennedy}

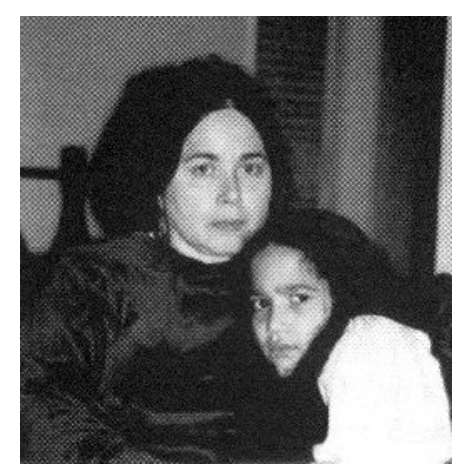

8.2 Karen Kennedy and daughter, Heather Kennedy

Most of the specifics surrounding her father's death are hazy for Karen.

One memory that stuck out in her mind was her mother's reaction to Kenneth's death. "Everybody was devastated, like the world had ended, and his daddy was inconsolable, just a mess. But I remember standing beside my mama and she was as calm as ever, never shed a tear the whole time.” Her childhood ability to notice this lack of emotion from her mother was not lost on other relatives. Colleen Kennedy's reaction to her husband's death became the topic of many family conversations.

With speculation comes gossip, especially where a death is concerned. Kenneth Kennedy's tragic end and his wife's lack of reaction spawned a variety of theories. People speculated infidelity, suicide, and even murder as reasons behind the young man's death. One of the most popular stories Karen can remember was that N.B. Kennedy, the father who found his dead son and carried his lifeless body from the mine, was having an affair with Colleen. Some folks whispered it was 
N.B. himself who murdered the boy. That was why he made such a show of emotion and never wanted to speak of it again.

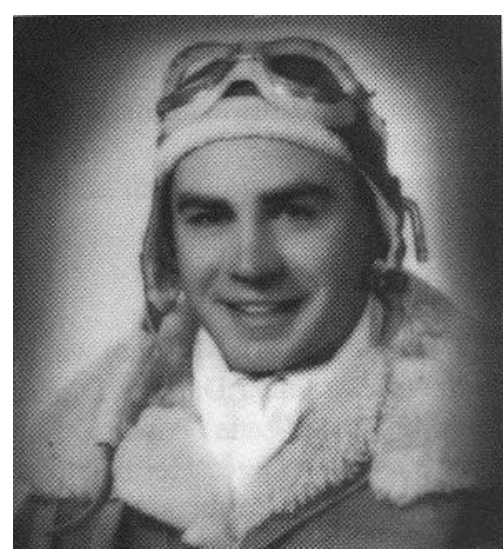

8.3 Kenneth Kennedy

When I left the East Coast this past summer on my trip back to Portland, my father and I stopped in Lexington, Kentucky to visit Karen again. She lives in a dilapidated old mansion in the downtown district, rooms filled with clutter, pictures, memorabilia of a life that I have just recently come to know. Although I had been intrigued by the story of her father since I can remember, I had never thought to visit or talk with her about it until my recent trip to Caney Ridge. Like the little kid in the backseat of his parents' car on the way to the mountains, I assumed no questions were to be asked on the topic. While there was little more information she could divulge, she did spend part of the evening showing me pictures from her childhood.

She also brought out a few artifacts: her father's WWII pilot wings, a military medal, and a tin stamp of his signature. Next she showed me his army pilot photo, the confident smile shining through the smoky, cracked glass and past the 
tarnished, silver frame. He is dressed in a soft fighter pilot's cap, goggles pushed back over the temple, wearing the same wings I held just moments earlier.

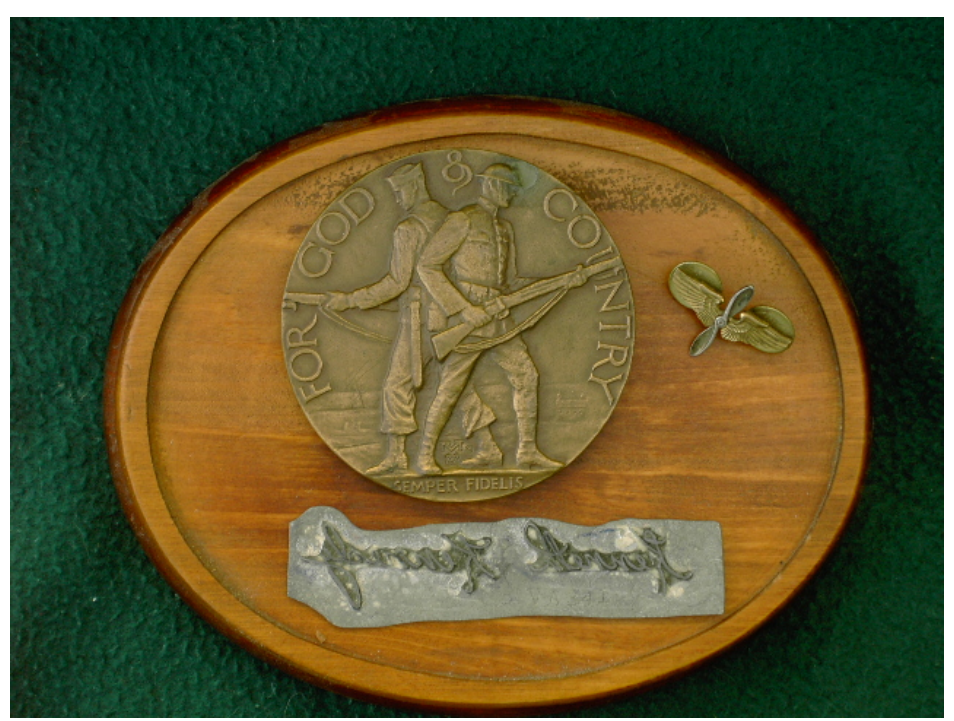

8.4 Kenneth Kennedy relics: For God and Country medal, tin type signature stamp, and pilot wings

As we prepared to leave the next morning, Karen placed the three cherished artifacts in my hands. She hugged me goodbye and said, "I can tell these mean more to you right now than they do me.” And, while I knew then, as I do now, that her words are not true, I take them anyway. This is her simple way of passing on the story, ensuring that it won't die. The wings, the medal, the name in intricate cursive sit in front of me now as I write these words, as if their owner was saying, “ I was here. I walked this same earth you trod, breathed this sweet air that fills your lungs. I may be gone now, but through these objects, peoples’ thoughts, your words, I live again, even if only for a brief moment.” 
In reading the stories, visiting the mystical settings, and talking to the sons and daughters of those who lived the legends I feel that I have barely scratched the surface, tossed a tiny pebble in the deep well of collective consciousness that is the Melungeon story. Even now, I can feel the rings resonating on the water as that pebble sinks deeper and deeper. It lies in the experience of traveling to Caney Ridge and Newman's Ridge with my parents, the shared exploration of our family story. It is present in the relics and artifacts from my journey - a brick from my grandfather's house, the wings of fallen pilot - cherished objects that still hold their owner's hopes and dreams.

I think of the immense oak in my great grandfather's front yard on Caney Ridge. How many hands have grasped its limbs and climbed its heights? Which of the names on my page, people linked to me by blood and thought and word that I never met in person, sat in its shade in the heat of a summer's day? How ironic it is to trace the bloodlines of family on the limbs of a metaphorical tree. If timber could only tell a story beyond the reading of its rings, share the history of its sap like so much blood in a person's veins, what secrets would it tell? We trace our family lineage, line by line, writing it down neatly on paper milled from the same timber its branches emulate. In this manner, we attempt to understand a time, long since passed, that we can never truly recreate. 


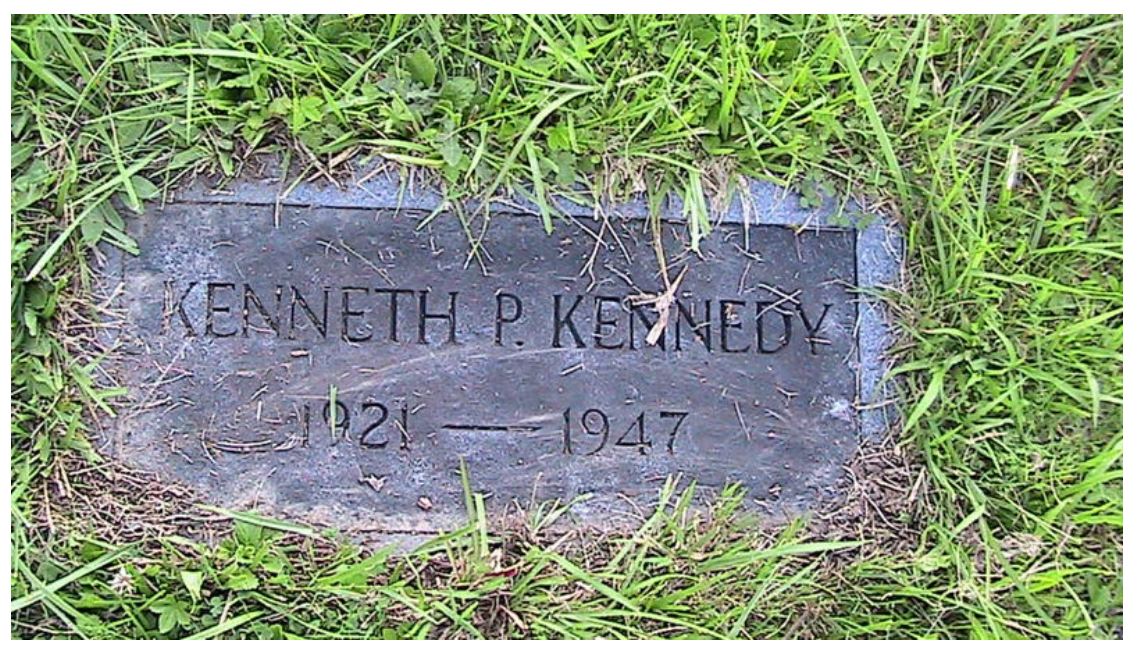

8.5 Kenneth Kennedy’s footstone

\section{Creating Personal Myth}

\section{The Writing of “Coal Black Heart”}

Before talking to Karen, I always had the image of Kenneth as a man of action, entering the mine to save a fallen comrade but dying as he clawed his way towards safety. He had been a larger than life character to me, always fighting the good fight, ever confident, eternally cast as the hero. Now, I thought of him in a somewhat different light: the cuckold, the coward, the man unable to cope with daily life. Neither of these scenarios can be proven.

My research about the Melungeons sparked me to begin a series of short stories in the fall of 2006. In the story about my Great Uncle Kenneth, "Coal Black Heart,” D.W. Caudill, the main character is the father of a son who doesn't look like him. His wife won’t show him any affection; his mining business is failing, and he is faced with a disaster at the mine that he considers to be his fault. While 
D.W. is based loosely on Kenneth Kennedy, he is as weak a man as Kenneth was strong in my mind. He enters the mine in what appears to be a heroic attempt to save lives, but in actuality, he is descending into the darkness of his own shadowed soul. As he takes his last steps towards the fallen miners, D.W. chooses to give up on the uncertainty of life for the sureness of death. He is so weak that he cannot even take responsibility for his own death, masking it as a rescue attempt instead of a suicide.

The story "Coal Black Heart" is accompanied by a poem of the same title. One tradition in the Blue Ridge Mountains is to share true stories through poetry and song. An example is the story of Tom Dula, a mountain resident who murdered his girlfriend Laura Foster. As with Kenneth Kennedy’s death, there are an abundance of theories as to why Tom murdered Laura, but the truth has become muddled over the years of retelling. The story of Tom Dula has been immortalized in the traditional song, "Tom Dooley," but even this telling of the tale changes facts with the misspelling of the main character's name.

Most of the people who can shed light on Kenneth Kennedy's death are long dead and buried. Even if they were here to tell the tale, the truth would be so clouded by the haze of years that it might not be trustworthy. It has left the confines of reality and entered into the murky, uncharted waters of mythology. 


\section{IX}

\section{Coal Black Heart:}

\section{A Fictionalized Interpretation of a Family Story}

It's a struggle to find my way in the dark, but I know this house like my name, like my own smooth palm, the recent blisters barely calloused over. This could still be a part of the dream. Pausing, I stare into the black, waiting for my eyes to adjust, but they never do. Is this that time when all is still and clear, the perfect shadow of reality that can never exist in the light of day. I could lose myself to this illusion, stare blindly into the void forever if the child would stop his wailing.

The child won’t rest, doesn’t fit in his own skin. His eyes are wild, ablaze with a fire that I could never harness. I try time and again to hold him in my arms, comfort the boy softly, rock him back to the sleep he never fully embraced, but he's all rigid, unresponsive to his daddy's touch. I think the worst, try to push the bad thoughts to the back of my head, forget them, but it never works. Once I think a thing, it becomes real, even if it can't be true. Can this child even be my son? I know she has never been with another man, feel it with my heart, my bones. But it's there, and thought becomes reality. I see them behind dark doors, in tight corners. Her lover never has a face; his features shift, but he means more to her than I do. They are laughing, always laughing at a joke I don't understand, laughing at me. Push it back. Forget all of this. It is just a part of the dream before I awake. 
Slowly shapes begin to create themselves anew in the upper hall. The first rays of pre-light dawn filter softly through the hall window. The floorboards begin to show a line of shimmering pink against the cold, dull wood. Heading towards the faint light, I shuffle blandly in the direction of the screams, fool myself into thinking that this time will be different. The boy will have my eyes; he'll fall asleep in my arms. My hand will finally comfort rather than corrode everything that it touches. His wails cease just before I reach the tiny room at the end of the hall. I painted these walls deep sky blue myself in anticipation of the boy's arrival. Festive flowers brought from the hospital are now wilting, slowly beginning to droop their way to the earth once more. Although it has only been two weeks, the child's unrest, his nightly outbursts feel eternal. They cast a somber shadow over the entire house.

No need to turn around and pretend to sleep once more. The dawning day is growing brighter by the moment. The child will only pick up where he left off as soon as my head hit the pillow anyhow. Walking past the now still room, I slowly make my way down the stairs, skipping the third one from the bottom; the deep squeak of the loose board could send the boy into a fit again. But just as I reach the last stair, the silence is broken by a pronounced ring, then a sharp pause, followed by another ring.

This shrill sound penetrates the air, slices it clean like the softest skin under a precise blade. I'm not used to the sound. The phone is only slightly older than the child; his cries are more familiar, more routine, although the two could be 
interchangeable at times. Picking up the receiver, I know it can't be good news, a call this early, this late, can never be good. At first, there is only silence at the other end. Who is it that speaks first? I break the sweet silence with words that don't seem real, a voice that is not my own,

“Hello.....hello. This is DW speaking. Is there anybody there?”

Nothing. Did the phone even ring, or have I imagined it? I almost have the earpiece in it’s cradle when a distant voice replies, “ Uh, yessir...uh Mr. Caudill sir. This here's Ulias from the swing shift. The foreman sent me to call you in as soon as you can make it. We got a problem, been an accident with the blasting. We got men in the hole still. Most is out, but a couple fellas got themselves trapped.”

What do I say? I am the man in charge, but no words are there when I need them.

“Now what happened? Who’s still down there? How many men are missing?” My words are rushed, haphazard. They are all I have right now though.

“Listen...um, I mean, look sir, you better get down here. That’s all I know, but the men are a bit riled. They're askin' for you. I'm sure we'll know more by the time you get here. I better get back now and see what I can do to help.”

I take a deep breath, try to calm my voice, steady my nerves and reply, "Yeah, yeah you're right. I'll be down....”

I stop in mid sentence, as the phone goes dead. I tell myself that Ulias is in a hurry. He has to get back to the other men to organize a team for the rescue, want 
to tell myself anything but the truth. They blame me, won't even give details I can work with. How long had the men been down there? When did they decide to call me? Not right away that's for sure. Probably called when they knew it was too late, maybe even waited a bit longer just to heighten their disdain, fuel their anger, give them my name, my face, my pale, soft hands to blame.

I hang up the receiver before I even realize that the boy is crying again. Hearing Lucy's footsteps in the hall, I know she's angry. Her hard, deliberate stomps echoing off the walls, emphatically remind me that I should be taking care of the boy, allowing her the rest she needs to recover. Her mood is sour, and I haven't seen her smile since she left the hospital. I thought having the child would make it like the times before, but it just keeps getting worse. She spent the last three months before the birth in a bed; a volatile pregnancy the doctors called it. Now she has to recover with bed rest from her ordeal of carrying the wailing beast. No, the boy can't be my son; he is too determined, too angry, too loud to be my blood.

By the time I reach the room, Lucy sits half awake in the rocking chair beside the crib, baby over her shoulder, eyes slit against the coming brightness of day. I put my hand on her free arm, but she pulls away, turns her head, stares at the wall. She won't look me in the eye, can't seem to piece our love back together. We are a family now, I know we can be happy again, if the child would only stop crying, let me hold him in my arms for just a little while. 
"I gotta go down to the mine early. Guess there’s been an accident, some men still trapped in the hole. They called to say they need me.” Even the words sound hollow, false. She continues to stare at the wall, as if composing her face to fit the proper reaction, before turning towards me with a concerned look, "Well I hope everything is okay. Those poor men.... Their poor wives waiting for them to come home... waiting.”

I nod, turn back towards the bedroom, wonder what to wear. I was going to wear the black jacket today, the one with three buttons. How can I think of this now? Now of all times when men are dying beneath the ground. No one else cares what I wear. Other people are busy with real thoughts that matter. I methodically dress, try to ignore what I am doing, push my stupid thought back down inside my head. But I can't. The voice it stays with me, echoes in my head, taunting and teasing. This mine was a mistake.

Every day I am slowly sinking deeper and deeper into a hole that I'll never escape. No money for the timber necessary to fully support my mine shafts. Not enough money to keep a full time safety inspector on duty. This business is bust; all of my effort is in vain. This accident, the cave in at my mine is my creation, my fault. It is more of a son to me than that screaming wailing child with another man's eyes.

The miners, my men, lose a little more faith each day. I try to hold a straight face, reassure them with false words, my mouth moving mechanically, “Things will get better. Sacrifice now will mean a bigger stake when the tides 
turn.” I lie so well that I can almost believe myself. Once that coal dust gets in a man's veins, he'll never leave the mine; once it fills his lungs, he finds it hard to breathe above ground, just doesn't fit in the land of the living any longer. I wish I had the honesty to mix red blood with coal, but my veins are as blue as my hands are soft. I can't fill the shoes I've been given, my hand me down suit is too big for me; I don’t have the barrel chest and full arms of my father. Did he look into my eyes and wonder whose child I was? They call men like me " a day late and a dollar short,” as I arrive penniless, hands covered in other men’s blood, guilty. Seems like daddy wouldn't have to ask himself what to say, what to do. He would be the one digging through the rubble to find the men. I remember daddy's work hardened hands, covered in deep scars, each one marking a decision made, an action set into motion, a goal achieved. I can't even imagine trudging through the darkness to grasp my fellow miner, how it would feel to pull him to the safety of the land above. I have to speak, but even before I let the words leave my lips, I know it's wrong, all wrong.

Driving methodically to the mine, I pass the house my daddy built from nothing, the house I was born in. It is smaller than my house, but even empty, dormant, it is more a home than I will ever build. I pass this place every day without so much as a thought, but today, I am the child once more, hands covered in dirt, digging my own imaginary mine beside the porch. My mama sits in the rocker by the door waiting for daddy to return, black faced and sweaty, white teeth shining beneath a spotted, coal streaked brow. I can't be more than four or five, 
but it is all so vivid. The fireflies are just beginning to blink against a hazy deep orange sky as the last rays of sun shine off of the blue black hills. Mama rocks back and forth knitting a sock or a scarf or something useful. She chants folk ballads in a high, nasal whine awaiting her husband's return.

I remember the words, because she always sang them, as if the song alone would bring her man home safely. And I guess they worked, because he always returned, tired but in one piece. Even as head foreman of the mine, daddy chose to put his pin on the board like every other man and go down into the shaft, work alongside his crew. He had a way about him that I just don’t understand,

Pulling into the mine lot, the first person I see is Smith the night supervisor. The men who work beside him every day, match him shot for shot at the bar, call him Smitty, but I can never bring myself to do so, haven’t earned the right. His puffy white cheeks are barely visible behind black smudges. He's one of the oldest workers at the Kenwood mine, knows the intricate passages like a second soul. I can sense the man's words before they roll off his tongue. Although they are so simple, their meaning is devastating.

"Cave in. Shaft number 4 at the lower end. More than half the boys broke surface, but we're still missing three heads by my count.”

Smith's mouth appears to be moving independently from the rest of his body. His darkened face and red-rimmed eyes remain perfectly still, emotionless. I picture in my mind the three brass pins hanging on the miner's shift board telling which men had yet to surface; who was still trapped down below. After I allow the 
proper time for the words to sink in, I hazard a response. "How long ago did this happen?”

Looking up in the air, as if the answers lay there, Smith waits a second or two before beginning.

"First man made it out about an hour ago, last one was about fifteen minutes behind him. I called Vern Mulllins, my morning relief, in early to question the crew and get the details for a rescue mission. I wanted to be the one to break the news to you. That's why I sent Ulias to call you in, but it's me that should be the one to tell you about this, not him. What I'm trying to say is... uh... this fell on my watch. It’s my responsibility. I just want you to know that.”

I know he doesn't believe this any more than I do, but I let him lie to me. We all need to keep up appearances. If he needs to feign responsibility now, why not allow him to be the martyr of the moment. The brisk morning air burns my nostrils; I think about the men below suffocating in thick blackness, wonder how long their air will hold out, how bad the cave in is. I am ashamed to fill my lungs, disgusted by the stinging coldness that surrounds me. This very substance, this thing that you can't see or touch is the difference between living and dying. Air is the body's fuel. It's coal; it's blood. Air is God.

I shift my stare from Smith to the shaft entrance. Miners are standing there, eager to rush in and save their fallen comrades, but Vern blocks their path with the crossed arms of authority. The men silently seethe at their own inability to help; their eyes dart back and forth looking for someone to blame, looking to me for 
answers I don't have and never will. It's my fault. I know it, and they know it. When you're waiting for something to happen, time drags its feet. Their angry, exhausted eyes are killing me, every pair has a face behind it, a face filled with heaviness, with immediacy, with scorn.

As I walk towards the shaft, I can begin to make out Vern's words. He is speaking directly to two of the men who made it out alive, Jack Rives and Ezra Hollis. We call them men, but they can't be older than twenty, just boys by all rights. They are exhausted, but the fire of youth and purpose fuels their anger. If Vern didn't cross his arms, they would run back in to the shaft, rush to the aid of the men still inside. Their determination and loyalty is as admirable as it is stupid. Vern keeps it simple, “If you're out, you stay out. We'll organize here in a minute, send in fresh bodies with clear heads, not one of you lucky bastards with piss and fire runnin’ in your veins.”

A few yards from the men, I stop and look directly into Smith’s eyes once more. I've finally found the words that I was looking for earlier. They flow so smoothly that it doesn’t even feel like my voice saying them. "Good move callin' Vern. If he can’t talk sense into those boys, he’ll knock it into 'em for sure. Don’t take this on yourself, Smith. You might be in charge of them boys, but the earth is gonna do what it pleases. There’s no blame here, remember that.” He looks back at me feigning relief.

Other men, fresh workers awaiting the morning shift, approach from behind and intermingle with the night crew, silently sharing in the burden of loss. Without 
waiting for Smith’s reply that will never come, I pass through the circle of men that has formed at the mouth of the mine to stand beside Vern who is speaking to the group as a whole.

"Now all of you listen, and hear me well. Step back and think for a minute. Ain't a one of you going back down in this here mine. Try it and I'll sock ya. You all made it out for a reason, and it ain’t right to go bucking fate like that. If you were on that shift and made it out to tell, you're gonna step over to the break room, sit down, and pray to the holy ghost for sparing your lives. We got fresh bodies comin' on as we speak, and if anyone is passing by me, it will be volunteers from that lot.” Vern scans the crowd, letting his statement sink in, before turning to me for confirmation.

I pause before speaking, let Vern's words sink in. My mind is filled with blankness. I want to piss myself, grab my head and run screaming into nothingness. Pairs of restless beady eyes bore holes into my body. I sigh, bow my head, raise it again, and open my thin, weak lips to speak.

“Vern speaks true: he knows this mine better than any of us. I don’t wanna lose any more of you men in this hole today. Now that we've settled that, I need to get the details of what happened straight. First to see the fall, and the last man out stay here. Everybody else, follow Vern and tell him what you know. Before anybody goes back down, they need to know exactly what they're getting into.”

Vern leads the men away from the entrance and begins questioning them in a softer tone. I’m left with Ezra Hollis and Jimmy Spruce. 
Ezra doesn't have to bow his head and wait, he breaks the silence right away, "I seen what happened first. Most men were just a few yards down the number 4, just past last week’s blast site at the t-neck bend. Support beams were already in place, near the bend, but we didn't have nearly enough wood beams to shore her up properly. So Rives and Spruce here went in deeper to place some more supports before we all joined them. I was about five feet behind them. Rod Burns, Clem Staley, and Buckeye went ahead of them down the shaft to find good spots to put more beams. Same as we always do on a new vein, business as usual. Then it all just went to shit. I could still make out Clem's light, but Rod and Buck were out of sight. I'm not sure if Clem tripped over an unset beam on the floor or what, but he must have caught his fall against an unsupported wall. I heard a crashing sound and their lights went dark. I waved at Rives and Spruce to follow me before turning around and hightailed it out of there. I figured dead or trapped, I wouldn’t be able to help nobody.”

I nod sympathetically, but the words "not enough support” keep echoing around my brain. The weight is too much, simply not enough support to hold it. My tongue swells; I can’t swallow. I look to Jimmy Spruce, “Go ahead son, tell me what you remember.” The words come out sticky, insincere. Why do I call him son? He’s probably only a few years younger than me.

Spruce stands less than an arm's length from both of us, but his words come from far away. “Things happened so quick. One minute Rives was to my left, and the next, he was gone back the way we came towards the surface. The rock fall 
couldn’ta been more than ten feet ahead a me. The light just faded to dark, dust...couldn't move or even breathe for a bit, felt like someone was sittin' on my chest, stealing my breath. I just hunkered down and waited for something to happen. The noise was gone quicker than it came. All that was left was a trickle of dust. I started hacking black clouds, trying to find somewhere to move in the pitch black. I could hear muffled words, wanted to move towards them, help somehow, but I just backed away towards the light instead. I should have done something more.” His voice is limp, even weaker than my own. He hangs his head, shakes it back and forth as fresh tears wind a path down his cheeks, washing the black away in streaks.

I should say something, but the words just won't come. I wish I were strong, wish I could put my hand on Spruce's shoulder, reassure him he did all he could, help him sort through the conflicting waves of elation and remorse. I pause just a bit too long, and he looks up, fishing for a response that just won’t come. "I see... anything else you remember?” My teeth slice the words precisely. I should say more, but I can't.

“No sir, not as I recollect. It all happened so fast. I don’t even remember how I got out, seems like a dream almost.” His eyes fix on mine for a few seconds more and then sink to the ground.

"You did all you could," comes that voice again from inside of me that is not mine. 'Don’t beat yourself up over chance; you can’t change fate. You're more help up here alive than below in the unknown. Now go tell Vern what you 
just told me. We all need to get the facts straight.” My words hang weightlessly in the air, as if they have been lying in wait all along.

Day has now fully broken over the Kenwood Mine. Sun slowly warms up the frozen, hard dirt ground. In the light of day, I can see my breath exhaling against the morning chill. I want to reach out and touch the steam as it pours from my mouth. I want to hold it like the fireflies on a warm summer night, put it in a jar and keep it safe forever. But forever is just a word. It can’t describe a place, like the house I grew up in. It can’t describe a love, like the one I have for Lucy as she coldly turns away and faces the wall. It can't even describe the men below, trapped in a small corridor, waiting for someone to reach a hand through the blackness, to steal them from their fate.

While the foreman and crew leader are busy with the other men, getting details in order, forming a rescue plan, I stand alone at the mouth of the mine. Three brass pins shimmer in the growing sunlight on the miner's shift board. Work bibs, carbide lamps, and other equipment hangs on pegs just inside the mine shaft. As I step into a pair of coveralls, I can feel myself growing. My chest is wider, and my arms can surely carry any weight.

The carbide lamp fits neatly over my helmet; it bursts to flame on the first click of the flint, creating a warm, blue-orange glow over the entire entrance to the shaft. It shimmers a fire dance off the rippled, smooth coal walls. The faint trace of my shadow on the floor looms large; it is so much bigger than me as I follow it into the dark unknown. I've never walked the shaft alone before, but somehow it 
just feels right, like every step I take has more purpose, less doubt. This strange terrain, beneath the earth, below my safe, comfortable routine feels like a dream, an all-knowing blur before the eyes awake. It is familiar, like my palm, the upstairs hall, the third skipped stair on my blind descent. I can feel the light of the world above growing smaller behind me, but I don't dare glance over my shoulder. I am going home for the first time, crawling back into the pitch black underworld, retracing all too familiar steps I’ve never taken before.

I don't even notice the motionless pile of a man on the floor until my foot brushes against it. Without even leaning down I know he is no longer of my world. Kneeling by his side, I can see it is Clem Staley. His eyes are barely open, squinting like he could sneeze at any moment. Hands stretch forward, towards the mouth of the mine; there are claw marks in the dirt floor from his last attempts to escape. Clem looks so peaceful, as if he is only resting for a moment here in a coal black womb, far down in this quiet, holy place. He is nestled in this cocoon, away from the harsh world above, taking all the time he needs to be reborn again.

I want to lie down beside him, take a short break, see what it feels like to fall into the deepest slumber, rest for just a little while. It takes me a minute to muster the courage to turn him over, almost afraid he will wake up, begin to wail like my son with wild eyes that aren't mine. I stand and push the lifeless body over with the toe end of my boot, and it slumps against the wall, the tongue slightly lolling out of the mouth, pink against pale lips. 
Then it hits me. My mind reels in beautiful all knowing confusion of the dream where light fades to darkness, to nothing. The carbide lamp flickers. I dim it low and breathe in lung deep the cold, damp air. I can't smell it or taste it or even feel it, but it is there... gas, natural deadly gas, and it is draining the life from me in a succulent, silent haze. I push Clem's tongue back behind his lips, and he is smiling at me again. Looking over my shoulder I can make out the faintest light of the mine's entrance. Up there, men are waiting, waiting for me to return with news of the others, the story from below. Which one will break the news to Lucy? Who will rock my baby boy to sleep at night while I'm away?

I sit down beside Clem, drape his arm around my neck. It is the easiest movement I have ever made. The paper will say that I was found just a few short yards from the entrance to the mine, almost close enough to taste the air above. Mine operator D.W. Caudill heroically dies in a failed rescue attempt at the Kenwood mine. He leaves behind a wife, a son... I say these words over and over in my mind as I turn off the lamp and accept the silent darkness like the warmest embrace. We are miners, Clem and I, fallen comrades far below the ground. I sit, and wait, breathing slower and softer, staring not towards the light, but back into the whispering darkness, forging my own peace beneath the ground, in this bitter black vein. 


\section{Coal Black Heart}

He saw the light before him

Then he quickly turned away

Cause the thoughts of pushing blindly

Through another wretched day

Proved too much weight to handle

Far beyond his strength to bear

His soul was forged beneath the ground

Had a diamond sealed within

Coal Black Heart

Never see the light of day

That dark ore runs deep

Spreads its sin inside my veins

The voices kept on calling

From the living up above

But the earth below it beckoned

Whispered lullabyes of love

Saying six feet down ain't nothing

When your life's work is underground

And no pine box can hold a soul

That's lost before it's found

Coal Black Heart

Never see the light of day

That dark ore runs deep

Spreads its sin inside my veins

Light faded fast behind him

And with it dimmed his fate

As he saw one of the miners

And realized it was too late

Still he muscled through the motions

Shouldered up the lifeless load

Of another man fell victim

To the mining of the coal
Coal Black Heart

Never see the light of day

That dark ore runs deep

Spreads its sin inside my veins

Staring deep into the darkness

Feeling full its cold embrace

He slowly turned towards the light

And all his struggles left to face

Pitch of black behind him whispered

Sang a simple somber sigh

About the beauty of the void

And the choice to live or die

Coal Black Heart

Never see the light of day

That dark ore runs deep

Spreads its sin inside my veins

Saw the light right there before him Then he quickly turned away As the thoughts of pushing blindly Through another wretched day

Filled his mind with silent sorrow And his heart with bitter dread He traded up the toil of living for the freedom of the dead.

Coal Black Heart

Never see the light of day

That dark ore runs deep

Spreads its sin inside my veins

Spreads its sin inside my veins

Spreads its sin inside my veins 


\section{References}

\section{Works Cited}

Aswell, James. “The Lost Tribes of Tennessee’s Mountains.” Nashville Banner 22 Aug. 1937.

Brake, Katherine Vande. How They Shine: Melungeon Characters in the Fiction of Appalachia. Macon, GA: Mercer University Press, 2001.

Burnett, Swan M. “A Note on the Melungeons.” American Anthropologist Oct. 1889: 347.

Callahan, Jim. “Lest We Forget: The Melungeon Colony of Newman's Ridge. United States: The Overmountain Press, 2000.

Dromgoole, Will Allen. “Land of the Malungeons.” Nashville Sunday American 31 Aug. 1890: 10.

Finchum, Tina. The Electronic Front Porch: An Oral History Of the Arrival Of Modern Media in Rural Appalachia and the Melungeon Community

Gallegos, Eloy J. The Spanish Pioneers in United States History The Melungeons: The Pioneers of the Interior Southeastern United States 1526-1997. Knoxville, TN: Tennessee Valley Publishing, 1997.

Hashaw, Tim. Children of Perdition: Melungeons and the Struggle of Mixed Americans. Macon, GA: Mercer University Press, 2006.

Hirschman, Elizabeth Caldwell. Melungeons: The Last Lost Tribe in America. Macon, GA: Mercer University Press, 2005.

Horton, Sandy. “Caney Ridge Trip.” E-mail to author. 6 Mar. 2010.

Johnson, Mattie Ruth. My Melungeon Heritage: A Story of Life on Newman's Ridge. United States: Overmountain Press, 1997.

Kennedy, Brent. The Melungeons: The Ressurrection of a Proud People. Macon, GA: Mercer University Press, 1997.

Kennedy, Brent. “Re: Memories of Wise.” E-mail to author. 28 Feb, 2001.

“Kennedy, Kenneth.” Obituary. The Coalfield Progress. Norton, VA 25 May, 1947. 
Langdon, Barbara Tracy. The Melungeons: An Annotated Bibliography: References in Both Fiction and Nonfiction. Woodville, TX: Dogwood Press, 1998.

Mira, Manuel. The Portuguese Making of America: Melungeons and Early Settlers of America. Franklin, NC: P.A.H.R. Foundation, 2001.

Overbay, DruAnna Williams. Windows on the Past: The Cultural History of Vardy, Hancock County Tennessee. Macon, GA: Mercer University Press, 2005.

Plecker, Walter. “1930 Plecker Letter.” Melungeon Heritage Association. 5 Aug. 1930 http://www.melungeon.org/node/89.

Plecker, Walter. “1929 Plecker Pamphlet.” Melungeon Heritage Association. 1929 http://www.melungeon.org/node/88

Stuart, Jesse. Daughter of the Legend. New York: McGraw Hill, 1965.

The Order of the Silver Apple. Brandy Jack and Beyond: A Mullins Family History. Austin, TX: Armstrong Printing Inc., 2003.

“Virginia Racial Integrity Act of 1924.” Virginia Center for Digital History. 1924 http://www2.vcdh.virginia.edu/

West, John Foster. The Ballad of Tom Dula. Durham, N.C.: Moore Publishing Co. 1977. 


\section{Photo Credits}

1.1. Family Picture

1.2. http://news.bbc.co.uk/2/hi/americas/384502.stm

1.3. www.melungeons.com/ articles/a2003.htm

1.4. www.melungeons.com/ articles/a2003.htm

1.5. http://Urun.gittigidiyor.com

2.1. www.lisaalther.com/

2.2. etc.usf.edu/clipart/62300/62315/62315_croatan.htm

2.3. www.econ.ohio-state.edu/ jhm/arch/batcrk.html

2.4. www.badarchaeology.net/ data/ooparts/metcalf.php

2.5. learnnc.org

2.6. Shepherdhistorical-melungeons.blogspot.com.jpg

2.7. http://www.jgoins.com/Union6_speech.htm

2.8. www.lib.utk.edu/.../ authors/dromgoole-w.html

3.1. http://www.melungeon.org/node/171

3.2. Family Picture

3.3. Kennedy, Brent. The Melungeons: The Ressurrection of a Proud People. Macon, GA: Mercer University Press, 1997.

4.1. www.lintott.web.skysurfer.ca/ pages/mullins2.html

4.2. The Order of the Silver Apple. Brandy Jack and Beyond: A Mullins Family History. Austin, TX: Armstrong Printing Inc., 2003. pg. 14

4.3. picasaweb.google.com/.../ yUyzGkdpq1FI6kqKPAXBgw

5.1. Family Picture

5.2. Family Postcard

5.3. Family Picture

5.4. Family Picture

5.5. Family Picture

5.6. Family Picture

5.7. Family Picture

5.8. Family Picture

5.9. Family Picture

6.1. www.aca-dla.org/.../ KingCollege\&CISOSTART=1,61

6.2. www.jgoins.com/

6.3. web.knoxnews.com/ special/0517scandal/

6.4. www.historical-melungeons.com/ mmullins.html

7.1. Family Picture

7.2. Family Picture 
7.3. Family Picture

7.4. Family Picture

7.5. Family Picture

7.6. Family Picture

7.7. Family Picture

7.8. Family Picture

7.9. Family Picture

8.1. Family Picture

8.2. The Order of the Silver Apple. Brandy Jack and Beyond: A Mullins Family History. Austin, TX: Armstrong Printing Inc., 2003. Pg. 189

8.3. The Order of the Silver Apple. Brandy Jack and Beyond: A Mullins Family History. Austin, TX: Armstrong Printing Inc., 2003. Pg. 179

8.4. Family Picture

8.5. Family Picture 


\section{Appendix A: Virginia Racial Integrity Act of 1924}

\section{An Act to Preserve Racial Integrity}

1. Be it enacted by the General Assembly of Virginia, That the State Registrar of Vital Statistics may as soon as practicable after the taking effect of this act, prepare a form whereon the racial composition of any individual, as Caucasian, negro, Mongolian, American Indian, Asiatic Indian, Malay, or any mixture thereof, or any other nonCaucasic strains, and if there be any mixture, then the racial composition of the parents and other ancestors, in so far as ascertainable, so as to show in what generation such mixture occurred, may be certified by such individual, which form shall be known as a registration certificate. The State Registrar may supply to each local registrar a sufficient number of such forms for the purpose of this act; each local registrar may personally or by deputy, as soon as possible after receiving said forms, have made thereon in duplicate a certificate of the racial composition as aforesaid, of each person resident in his district, who so desires, born before June fourteenth, nineteen hundred and twelve, which certificate shall be made over the signature of said person, or in the case of children under fourteen years of age, over the signature of a parent, guardian, or other person standing in loco parentis. One of said certificates for each person thus registering in every district shall be forwarded to the State Registrar for his files; the other shall be kept on file by the local registrar. Every local registrar may, as soon as practicable, have such registration certificate made by or for each person in his district who so desires, born before June fourteen, nineteen hundred and twelve, for whom he has not on file a registration certificate, or a birth certificate.

2. It shall be a felony for any person wilfully or knowingly to make a registration certificate false as to color or race. The wilful making of a false registration or birth certificate shall be punished by confinement in the penitentiary for one year.

3. For each registration certificate properly made and returned to the State Registrar, the local registrar returning the same shall be entitled to a fee of twenty-five cents, to be paid by the registrant. Application for registration and for transcript may be made direct to the State Registrar, who may retain the fee for expenses of his office.

4. No marriage license shall be granted until the clerk or deputy clerk has reasonable assurance that the statements as to color of both man and woman are correct.

If there is reasonable cause to disbelieve that applicants are of pure white race, when that fact is stated, the clerk or deputy clerk shall withhold the granting of the license until satisfactory proof is produced that both applicants are "white persons" as provided for in this act.

The clerk or deputy clerk shall use the same care to assure himself that both applicants are colored, when that fact is claimed. 
5. It shall hereafter be unlawful for any white person in this State to marry any save a white person, or a person with no other admixture of blood than white and American Indian. For the purpose of this act, the term "white person" shall apply only to the person who has no trace whatsoever of any blood other than Caucasian; but persons who have one-sixteenth or less of the blood of the American Indian and have no other non-Caucasic blood shall be deemed to be white persons. All laws heretofore passed and now in effect regarding the intermarriage of white and colored persons shall apply to marriages prohibited by this act.

6. For carrying out the purposes of this act and to provide the necessary clerical assistance, postage and other expenses of the State Registrar of Vital Statistics, twenty per cent of the fees received by local registrars under this act shall be paid to the State Bureau of Vital Statistics, which may be expended by the said bureau for the purposes of this act.

7. All acts or parts of acts inconsistent with this act are, to the extent of such inconsistency, hereby repealed.

\section{Appendix (excerpt)}

Alexander Francis Chamberlain, A.M., Ph.D., Assistant Professor of Anthropology, Clark University...says: "In some regions considerable intermixture between negroes and Indians (Science, New York, Vol. XVII, 1891 pp. 85-90), has occurred, e.g., among the Pamunkeys, Mattoponies, and some other small Virginia and Carolinian tribes." "It is also thought probable that many of the negroes of the whole lower Atlantic coast and Gulf region may have strains of Indian blood." This probably accounts for the increasing number of negroes who are now writing to our Bureau demanding that the color on their birth certificates and marriage licenses be given as "Indian." 


\section{Appendix B: A Letter By Walter Plecker}

Bureau of Vital Statistics

State Department of Health

Richmond

August 5, 1930

Mr. J. P. Kelly

Trustee of Schools,

Pennington Gap,

Lee County, Virginia

Dear Sir,

Our office has had a great deal of trouble in reference to the persistence of a group of people living in that section known as "Melungeons," whose families came from Newman's Ridge, Tennessee. They are evidently of negro origin and are so recognized in Tennessee, but when they have come over into Virginia they have been trying to pass as white. In a few instances we learn that they have married a low type of white people which increases the problem.

We understand that some of these negroes have attempted to send their children to the Pennington Gap white school and that they were turned out by the School Board. Will you please give us a statement as to the names of the children that were refused admittance into the white schools and the names and addresses of their parents. If possible, we desire the full name of the father and the maiden name of the mother.

As these families originated out of Virginia, our old birth, death, and marriage records covering the period, 1853 through 1896, do not have them listed by color as are those whose families have lived in Virginia a number of generations. They are demanding of us that we register them as white, which we persistently refuse to do. If we can get a statement that the School Board refused them admittance into the white schools, we can use that as one of the grounds upon which we would refuse to classify them as white. That, of course, is a matter of history and does not involve any individual but the whole School Board, the responsibility thus being divided up, while few individuals who write to us as to their negro characteristics are willing to have their names used or to appear in court should it become necessary. This makes it very difficult for us to secure necessary information to properly classify them in our office. If the School Trustees will co-operate with our office and will refuse admittance into the white schools and give us information when such refusals are made, we can without great difficulty hold them $\mathrm{n}$ their place, but this co-operation is very essential.

I do not know who is the Clerk of the School Board or who would be the proper one to apply to but your name has been given to me.

Yours very truly, Walter A. Plecker State Registrar 